\begin{abstract}
UNIVERSIDADE DE SÃO PAULO
FACULDADE DE FILOSOFIA, LETRAS E CIÊNCIAS HUMANAS

DEPARTAMENTO DE LETRAS ORIENTAIS

PROGRAMA DE PÓS GRADUAÇÃO EM LÍNGUA HEBRAICA, LITERATURA

E CULTURA JUDAICAS
\end{abstract}

GENHA MIGDAL

\title{
MÊNDELE E O PEQUENO HOMENZINHO
}




\author{
UNIVERSIDADE DE SÃO PAULO \\ FACULDADE DE FILOSOFIA, LETRAS E CIÊNCIAS HUMANAS \\ DEPARTAMENTO DE LETRAS ORIENT AIS \\ PROGRAMA DE PÓS GRADUAÇÃO EM LÍNGUA HEBRAICA, LITERATURA \\ E CULTURA JUDAICAS
}

GENHA MIGDAL

MÊNDELE E O PEQUENO HOMENZINHO

Tese de doutorado apresentada como exigência parcial para obtenção do grau de Doutor em Língua Hebraica, Literatura e Cultura Judaicas da Faculdade de Filosofia, Letras e Ciências Humanas da Universidade de São Paulo, sob orientação da Prof. Dra. Nancy Rozenchan 


\section{FOLHA DE APROVAÇÃO}

Genha Migdal - Mendele e o Pequeno Homenzinho. Tese apresentada ao programa de Pós Graduação em Língua Hebraica, Literatura e Cultura Judaicas, Faculdade de Filosofia, Letras e Ciências Humanas da Universidade de São Paulo, como parte dos requisitos necessários à obtenção do título de Doutor em Letras.

São Paulo, de de

\section{Banca Examinadora}

Prof. Dr. Instituição

Julgamento Assinatura

Prof. Dr. Instituição

Julgamento Assinatura

Prof. Dr. Instituição

Julgamento Assinatura

Prof. Dr. Instituição

Julgamento Assinatura

Prof. Dr. Instituição

Julgamento Assinatura 


\section{RESUMO}

A presente tese aborda o primeiro livro escrito em ídiche por Mêndele Môikher ${ }^{1}$ Sfórim, Dos Kleine Mêntshele (O Pequeno Homenzinho) através de várias leituras do mesmo, em mais de uma versão, às quais sucedeu-se uma traduçãocuidadosa para o português. Faz considerações e referências sobre vida e obra do autor, cognominado jocosamente, por Shólem Aleikhem, de "o avô da moderna literatura ídiche". Ele foi também um dos precursores do ressurgimento da língua hebraica. Shólem Yákov Abramovitsh, seu verdadeiro nome, foi um dos importantes intelectuais conscientes do momento histórico e do processo linguístico de seu povo, no final do século XIX, no leste europeu, ao qual propunha auto respeito, profissionalização e não renegação do judaísmo. A escolha de seu pseudônimo, Mêndele, o vendedor de livros, serve de pretexto para a sua participação como personagem das histórias, dada a importância e atuação de tal profissional na sociedade retratada. O texto ídiche é permeado de frases e citações em hebraico que foram trazidas para o português no mesmo padrão de linguagem do texto original.

Palavras chave: tradução, literatura ídiche, expressões idiomáticas em ídiche, língua ídiche, Mêndele, Dos Kleine Mêntshele.

\footnotetext{
${ }^{1}$ Foi utilizado o dígrafo "kh", para transliterar o som gutural do hebraico e do ídiche, como a letra "J" do espanhol. O dígrafo "sh" é utilizado para transliterar o som de "x" (como em taxa).

A letra "k" é utilizada para o som de "qu" do português, ou do "c" seguido de "a, o, u".
} 


\section{ABSTRACT}

This dissertation studies Dos Kleine Mentshele - The Little Man the first book ever written in yiddish by the writer Mendele Moikher Sforim through many readings of it in more that one version, followed by careful translation into Portuguese. It makes considerations and references about Mendele's life and work. He was nicknamed by Sholem Aleikhem the "grandfather of the Modern Yiddish Literature". He was one of the precursors of the revival of the Hebrew language. Sholem Yakov Abramovitch, his real name, was one of the most important intellectuals aware of the historical moment and of the linguistic process of his people at the end of the $19^{\text {th }}$ century in Eastern Europe, and suggested self respect, professionalization and no Jewish denial for the historical moment and the linguistic process. The choice of his pen name, Mendele, the book peddler, allows his participation as personage of his stories because the significance and acting od such professional in the described society. The Yiddish text is permeated by Hebrew sentences and quotations brought to Portuguese at the same linguistic level.

Key words: translation, yiddish literature, Mendele, idiomatic expressions, yiddish language, Dos Kleine Mentshele. 


\section{ÍNDICE}

Introdução.

Dados Biográficos de Mêndele

.08

Relação das Obras de Mêndele em Primeira Edição

Considerações sobre Mêndele 16

O Ídiche de Mêndele 19

O Hebraico de Mêndele 19

Conclusões. 20

Considerações sobre o Pequeno Homenzinho .21

Expressões Idiomáticas em Dos Kleine Mentshele. .23

O Pequeno Homenzinho. 29

Bibliografia. 153 


\section{INTRODUÇÃO}

A semente inicial do presente trabalho foi uma citação de David Frishman: "Mêndele acolheu toda a vida judaica na ruela da pequena cidadezinha na Rússia, durante a segunda metade do século XIX e nos deu um quadro poderoso com todas as particularidades e liberdades. Se, por exemplo, um dilúvio varresse a terra apagando as marcas deixadas pela vida judaica, se apenas sobrassem poucas obras de Mêndele, elas seriam suficientes para resgatar a vida judaica com todos os pormenores" 2 .

Não houve um dilúvio, mas houve uma Shoá (Holocausto) que se encarregou de aniquilar essa vida judaica e motivou a recente revalorização deste autor, especialmente em Israel.

Por sugestão de minha orientadora, Dra. Nancy Rozenchan, surgiu meu interesse em pesquisar vida e obra do autor. Li vários de seus livros em ídiche, alguns em mais de uma versão, devido ao fato de que o autor os alterava a cada nova edição para aprimorá-los e também atualizá-los, adequando-os à realidade de seus leitores.

A obra de Mêndele foi pouco traduzida em geral. Em português, no Brasil, há a tradução de Massoes Binyomin Hashlishi - Aventuras de Benjamim III - por Paula Beigelman, com sabor bem abrasileirado, inclusive nos nomes próprios. Há também um trecho do mesmo livro inserido em $O$ Conto Ídiche, da coleção judaica da Editora Perspectiva (São Paulo, 1966): Viva os Judeuzinhos Vermelhos, uma narrativa satírica e saborosa sobre o quixotismo de Cervantes na vivência judaica.

Meu enfoque foi lingüístico, consistindo numa tradução que visou trazer para o idioma português do Brasil, uma síntese da cultura judaica do leste europeu. Mergulhei no ídiche de Mêndele para entender o que ele queria dizer, qual era a sua mensagem para o leitor. A tarefa a que me propus foi fazer o leitor brasileiro, munido de sua realidade cultural e de sua linguagem, receber e entender a mesma mensagem.

\footnotetext{
${ }^{2}$ Retirado do livro de Dan Miron, Der imaj fun shtetl (A imagem da cidadezinha), pág. 28.
} 


\section{DADOS BIOGRÁFICOS DE MÊNDELE}

A biografia de um escritor pode dar, às vezes, subsídios para uma melhor compreensão do mesmo, bem como, sua localização históricogeográfica.

Nasceu em Kapulie, região de Slutsk, Rússia Branca (hoje Belarus), em 1835 ou 1836 e faleceu em Odessa em 08-12-1917.

Seu pai, Haim Moishe Broida, era um estudioso e ativista comunitário; por vezes escrevia em hebraico. A mãe, Sara Nessi, estudada, lia textos dos livros sagrados para as mulheres. Sua cidade natal não se destacava entre as demais da região de moradia permitida aos judeus; destacava-se pela natureza exuberante.

O pai se empenhou especialmente na educação do filho, cujos talentos foram reconhecidos desde cedo. Aos onze anos encerrou os estudos com o rabino mestre Yossef Hareuveni e voltou a estudar com o pai. Este período não durou muito. O sustento da família foi decaindo e o pai, responsável pela "taxa da carne", que era cobrada dos judeus, foi perdendo sua fonte de renda. Devido à crise, o consumo de carne diminuíra.

Seu pai morreu na época de seu bar mitzvá, aos quarenta e um anos. Desde então, Mêndele começou a perambular pelas yeshivot (academias de estudos religiosos), dentro da geografia linguística e cultural do leste europeu, especialmente da Lituânia. Conheceu a comunidade dos khassidim, judeus piedosos ${ }^{3}$. Em todos esses lugares estudou com os mais brilhantes mestres. Após dois anos de andanças retornou à sua cidade. Sua mãe casara-

\footnotetext{
${ }^{3}$ No último ano do século XVII nasceu em Okup, Podólia, Israel Baal Shem Tov, o fundador do khassidismo, um movimento místico religioso cuja plataforma democratizou a religião tornandoa accessível aos judeus pobres, que não tinham a possibilidade de dedicar-se somente aos estudos, e cujo mote era a alegria de viver e a aproximação a Deus. "Fé e não temor, pois onde há temor, não há alegria". Suas prédicas foram anotadas por seus alunos e depois difundidas numa linguagem fácil, de domínio popular. Divulgavam ensinamentos e biografias de seus rabinos e líderes em língua ídiche, que alcançou assim grande desenvolvimento.

$\mathrm{Na}$ Lituânia surgiu uma linha de oposição a esse movimento de popularização da religião, liderada por rabinos mitnagdim, oponentes, e também por grandes estudiosos.

Alguns rabinos líderes do khassidismo se auto intitulavam tzadikim, justos e íntegros, exigindo de seus seguidores obediência e pagamentos, que em alguns casos, permitiram o gozo da luxúria. Grandes massas judaicas permaneciam dentro de um medievalismo supersticioso e ignorante, vítimas imersas na fé mística, controladas e exploradas por rebes e tzadikim.

Este movimento khassidico perdura até a atualidade, porém, com embasamento, tolerância e adaptação à contemporaneidade.
} 
se novamente e seu padrasto tinha filhos do primeiro casamento, dos quais Mêndele se tornou professor, para não depender economicamente da família. Mudaram-se, então, para uma aldeia próxima, cuja natureza influenciou Mêndele para escrever seu primeiro poema em hebraico, quando, então, foi descoberto seu pendor para a sátira. Voltou a Kapulie para a casa de estudos. Acompanhou, em seguida, sua tia aguná, esposa abandonada, em sua peregrinação pelas terras de Volínia, Ucrânia e Podólia, em busca do marido desaparecido, integrando-se à comitiva de Avreml, o manco, que recolhia donativos pelo caminho e explorava Mêndele, fazendo-o declamar seus escritos. Ao chegarem a Kamenetz Podolsk, Mêndele conseguiu separar-se do grupo. A viagem deixou-lhe fortes impressões perceptíveis em sua literatura, que começou a se desenvolver influenciada pelo espírito da Haskalá, o lluminismo judaico ${ }^{4}$.

Conheceu A. B. Gottlober, destacado ativista da Haskalá, que pôs à sua disposição a imensa biblioteca, onde Mêndele se encantou com a filosofia alemã e com a literatura européia. As filhas do intelectual ensinaramIhe línguas e ciências naturais. Mêndele casou-se com sua primeira esposa,

\footnotetext{
${ }^{4}$ A haskalá foi um movimento cultural e político judaico, consequência direta da revolução industrial que modificara os padrões sociais e econômicos trazendo a incipiente classe média para a luta pelo poder político. Houve uma reavaliação dos valores políticos, morais e intelectuais.

Uma concepção libertária começou a se cristalizar. A declaração dos direitos do homem pela revolução francesa, em 1789, atraiu pensadores judeus que aderiram à causa da emancipação vinda de fora e tentaram, simultaneamente, uma emancipação vinda de dentro, através do conhecimento e da ascensão econômica.

A haskalá funcionou como elemento de ligação entre a identidade judaica específica religiosa, nacional e cultural - e a civilização do mundo ocidental. Na Europa do Leste elas não eram excludentes.

O cultivo do hebraico perdurou como plataforma central do programa da haskalá, bem como o ensino de ofícios como preparação para o domínio de uma vida produtiva. Paradoxalmente a língua ídiche foi utilizada como difusor cultural, pois literatura e conhecimentos europeus foram traduzidos para o ídiche, permitindo assim o acesso do conhecimento ao povo judeu.

Na segunda metade do século XIX, abastados banqueiros judeus e os magnatas das estradas de ferro de S. Petersburgo e Odessa criaram a "Sociedade para a promoção da cultura entre os judeus", que, além de difundir a língua russa, custeava a educação secular das crianças judias necessitadas e subsidiava a publicação de livros de conhecimentos úteis, além da imprensa. A escrita ídiche até fins do século XVIII e início do século XIX, restringia-se a fábulas religiosas, canções folclóricas e romances. Estes romances consistiam inicialmente em adaptações idichizadas de histórias cristãs e mais tarde de traduções de obras literárias européias. Limitava-se ao papel de língua recreativa feminina e de comunicação. Esta escrita só ganhou força quando a literatura hebraica da haskalá entrou em declínio, porque o número de leitores que dominavam o hebraico era reduzido e o nível literário destas obras não os satisfazia integralmente. Mêndele, um de seu introdutor, soube imprimir-lhe altos padrões literários e lingüísticos, transitando entre os dois idiomas: ídiche e hebraico.
} 
vivendo na casa do sogro e lecionando na escola local. Nesta época escreveu muito, especialmente sobre questões de educação; as várias versões de seus artigos circulavam pela cidade, pois Mêndele tinha o hábito de reescrever os seus textos. Gottlober chegou a publicar no jornal Hamaguid (ano I, no. $31 \mathrm{em}$ 1857) um artigo sobre educação com o título de "Mikhtav al Dvar Hakhinukh", (Carta sobre questões de educação), dirigida a um seu irmão melamed, professor de ensino elementar, que se queixara da profissão. Neste artigo estabeleceu os princípios da educação para obtenção de resultados satisfatórios - transformar os alunos em pessoas de confiança para a vida em sociedade. A sequência veio em forma de livro, o primeiro de suas obras, publicado três anos mais tarde como Mishpat Shalom, (A corte do magistrado) uma coletânea de artigos, que alvoroçou os intelectuais da época, traçando padrões de gosto literário e de saber. Sob influência da Haskalá empenhou-se na ligação da literatura hebraica com a realidade e também na divulgação de conhecimentos de ciências naturais. Assim, foi criada a série Toldot Hateva, (História natural) cujo primeiro volume foi apenas uma tradução do original alemão de mesmo título, de Lenz, e os demais foram enriquecidos por pesquisas do próprio Mêndele, ligando-os à Torá e ao Talmud em relação à zoologia e outros conhecimentos. Estes livros foram reeditados várias vezes.

Transferiu-se para Berditshev, após três anos, onde se casou em segundas núpcias com a mulher que viria a acompanhá-lo no decorrer de toda a sua vida. $\mathrm{Na}$ casa do rico sogro pode dedicar-se a escrever, inclusive na imprensa hebraica. Dedicou-se também a atividades comunitárias como biblioteca pública, educação para crianças pobres e a fundação de uma sociedade de apoio financeiro aos necessitados. Aproximou-se dos pobres, conhecendo o mundo da miséria e de coleta de esmolas.

Seu primeiro passo na beletrística hebraica foi Limdu Heitev, (Aprendam bem), publicado em 1862, em Varsóvia, e em 1868, em Odessa, com uma versão modificada com o nome de Haavot vehabanim, (Pais e filhos), e que fora traduzido para o russo, tendo tido grande aceitação. Esta obra utiliza uma linguagem bíblica.

Em seu livro seguinte, Ein Mishpat, (O âmago do julgamento), dedica-se a questões literárias e problemas de ética. 
Além de literatura e ciências naturais, começou a ocupar-se com ciências sociais, tendo traduzido do russo parte do livro História dos Russos para o hebraico.

Preocupa-se com o alcance dos seus livros e decide escrever em ídiche, para que o público leitor pudesse entendê-lo. Por este seu início em língua ídiche, Mêndele escreveu anos mais tarde: "Este meu texto foi a pedra fundamental na nova literatura ídiche. Desde aquela época minha alma ansiou pelo ídiche e eu o adotei para sempre. Proporcionei tudo o que ele necessitava e ele tornou-se uma grande figura bem dotada e me legou muitos herdeiros." ${ }^{5}$ Realmente os herdeiros não tardaram a surgir.

Seguiram-se: Dos Vintsh Fingerl (O anel mágico), em 1865, Di Takse (A taxa), em 1869 e também, Fishke der Krumer (Fishke, o aleijado), Der Luft Balon (O balão de ar) e Der Fish (O peixe), em 1870, estes dois últimos em colaboração de Binshtok.

Em 1873, publica Di Kliatshe (A Égua).

Estas publicações foram muito difundidas e transformaram seu autor na principal figura da literatura ídiche, lapidador de sua forma e estilo, tendo introduzido nela um nível artístico, até então desconhecido.

Devido à publicação de Di Takse, denunciando a corrupção dos coletores, vê-se obrigado a deixar Berditshev e instalar-se em Jitomir. Suas dificuldades financeiras só foram dirimidas quando em 1881 mudou-se para Odessa, assumindo a função de diretor da escola Talme Toire (Escola elementar para meninos pobres).

Simultaneamente à fecundidade em ídiche, Mêndele nunca deixou de escrever em hebraico, mesmo que em escala menor e temática diversa.

Mêndele chegou a considerar cada narina do nariz do judeu um dos dois idiomas. Hebraico e ídiche, usando-as indiferentemente, sem maiores considerações.

Continuou a participar da imprensa hebraica. No auge do debate sobre reformas na religião que transcorria com ímpeto na imprensa e na literatura hebraica, na década de setenta, Mêndele assumiu a palavra em uma

\footnotetext{
${ }^{5}$ Retirado do livro auto biográfico, publicado em 1899, Shloime Reb Khaim`s.
} 
série de artigos no jornal Hameilitz ( $\mathrm{O}$ advogado), com a denominação de "Tempo de Falar", em que externou sua posição sobre a necessidade de mesclar a cultura com a religião, acentuando, também, a necessidade do hebraico como difusor da cultura. Dirigindo-se aos escritores, reitera a difusão da cultura em detrimento da religião.

Sugeriu mudanças na educação judaica e criticou a depauperante situação econômica e de exploração na sociedade judaica, porém, não foi atendido.

Ateve-se, assim, a criar um centro literário ao seu redor, em Odessa. Preocupou-se em ampliar a utilização do hebraico rabínico acrescido à linguagem bíblica e entendeu a crítica de Dubnov ${ }^{6}$ a seu nível e estilo do hebraico, que de alguma forma era inacessível ao povo e demandaria comentários e explicações. O próprio Dubnov declarou que ao ler os livros auto biográficos de Mêndele, ouvia a melodia do shtetl, da cidadezinha.

Em 1886 começou a publicar no diário hebraico Hayom (O dia), o romance Besseter Raam (No esconderijo estrondeante) que fora escrito também em ídiche, em um estilo mesclado do hebraico, agora mais vivo, moderno e inteligível. Captou a vertente do hebraico de sua época, embora não tenha alcançado a pujança, calor e fluidez dos escritos em ídiche.

Os pogroms e o início da Revolução Russa, em 1906, fizeram-no sair de Odessa, onde ele era o líder dos escritores hebreus, e conduziram-no a Genebra, na Suíça. Nesta cidade celebrou os cinquenta anos de atividade literária, fato que foi comemorado em vários países. No início de 1908, retornou a Odessa, tendo sido homenageado nas diversas cidades por onde passou. Nos últimos anos de sua vida começou a publicar as suas memórias escritas em ambos os idiomas. Sua casa continuou sendo um lugar de encontro de intelectuais e escritores. Havia discussões literárias e políticas, onde quem sempre mais falava era o próprio Mêndele.

\footnotetext{
${ }^{6}$ Shimon Dubnov - (nasceu em 1860 - morreu em 1941 pela mão dos nazistas) em Riga. Foi um dos mais importantes historiadores judeus do século XX. Tinha uma concepção sociológica da história. Ajudou a organizar na Rússia, em 1906, o partido nacional popular judaico, o Bund, que era idichista e antissionista. Escreveu em dez volumes, uma história universal do povo judeu, acentuando os fatores sociais e culturais.
} 
Faleceu em 08 de dezembro de 1917. A seu enterro vieram dezenas de milhares de pessoas. Dez anos depois a municipalidade de Odessa erigiu-lhe um monumento com inscrição em ídiche e russo. 


\section{RELAÇÃO DAS OBRAS DE MÊNDELE EM PRIMEIRA EDIÇÃO}

1857 - 'Mikhtav al dvar hakhinukh", em hebraico, (Uma carta sobre educação).

1860 - "Coletânea de artigos de crítica literária" - original hebraico.

1862 - Limdu Heitev - (Aprendam bem) - Romance original em hebraico Varsóvia.

1864 - Dos kleine mêntshele - (O pequeno homenzinho) - em ídiche.

1865 - Dos vintsh finguerl, (O anel mágico) - novela em ídiche - versão hebraica Beemek Habakha.

1866 - 2ª coletânea de artigos em hebraico sobre a condição judaica Ein mishpat (O âmago do julgamento).

1868 - Haavot Vehabanim - em hebraico - (Pais e filhos) - "Eltern un kinder", em ídiche. Retrato da filosofia da Haskalá.

1869 - Fishke der krumer - (Fishke, o aleijado) - traduzido em 1909 para o hebraico como Sefer hakabtzanim.

1869 - Di Takse - (A taxa), onde aborda a exploração do imposto sobre a carne. Jhitomir. Em 1872 em Vilna.

1873 - Di Kliatshe - (A égua); uma alegoria à vida diaspórica e um protesto contra o antissemitismo. Em 1911 foi traduzida para o hebraico como Sussati.

1875 - Yidl - Uma história em verso com duas partes. Varsóvia.

Traduziu os Salmos para o ídiche, afim de torná-los acessíveis ao público que não dominava o hebraico.

1878 - Massoes Binyomin Hashlishi, traduzido para o hebraico em 1896, onde faz um paralelo a D. Quixote de Cervantes.

1879 - Luakh hassokhrim (Calendário dos Comerciantes), coleção de artigos úteis. Vilna.

1884 - Der Prisiv - (O recrutamento) - em ídiche. Drama em cinco atos sobre o serviço militar na Rússia que se prolongava por mais de 25 anos, ao qual eram enviados meninos de famílias pobres.

1886 - Besseter Raam - (No esconderijo estrondeante) - Original hebraico. Em ídiche, Tzurik Aheim (De volta para casa).

1887 - "Der nutzlekher calendar" (Calendário útil) - que continha informações importantes para judeus russos, publicado por cinco anos seguidos. 
1890 - Shem veyefet baagalá (Shem e Yefet - Sem e Jafé no compartimento do trem).

1892 - Lo nachat be Yaacov (Não confortável entre judeus).

1894 - In a shturem tzait - Ídiche - Em Tempo de Tormenta - Biyemei Haraash - em hebraico

Biyeshiva shel maala, uviyeshiva shel mata - ( $\mathrm{Na}$ assembléia de cima e na assembléia de baixo).

1899 - Shloime Reb Khaim's - Reshimot le toldotai. Notas biográficas em ídiche e hebraico 


\section{CONSIDERAÇÕES SOBRE MÊNDELE}

De acordo com Dan Miron ${ }^{7}$, Mêndele propagou uma literatura artística, estilística e ideológica diretamente dentro da modernidade. Conciliou sua própria modernidade dentro das normas do Humanismo europeu com o tradicionalismo de uma civilização medieval.

Inicialmente, devido às suas preocupações com a Haskalá, o lluminismo, e por efeito da literatura científica alemã, lançou-se ao trabalho de educar por meio de traduções e divulgações das ciências naturais em hebraico, que foram várias vezes reeditadas. Ingressou na ficção com a novela hebraica: Pais e filhos.

O autor sempre se considerou um "naturalista", um pesquisador do habitat social e humano do judeu na Europa Oriental.

Nesta primeira fase a utilização do hebraico torna Mêndele um dos fundadores da moderna prosa hebraica, utilizando o hebraico bíblico, no qual se misturavam poucos elementos pós bíblicos.

A partir do lançamento de Dos Kleine Mentshele "1864", em ídiche, põe-se a criar uma série de romances na língua das massas com o intuito de "ir ao povo", ensinando e renovando. Imprimiu um impulso a esta literatura que deixou de ser popular transformando-se numa das grandes literaturas européias.

Mêndele deu voz ao shtetl, pequena cidade, permitindo projetar suas prioridades inerentes, valores e fantasias.

Captou todos os aspectos do shtetl: circunstâncias econômicas, estratificação social, detalhes etnográficos, especificações do habitat, indumentária e assessórios, rituais, festas, busca intelectual, relações matrimoniais e experiências com a infância, adolescência, maturidade e velhice. Povoou sua obra com personagens judias de várias classes e profissões.

Mêndele foi um satírico violento, concentrando seus ataques contra a miséria, a ignorância e a aspereza da vida no gueto.

Sua pena, como um bisturi, dissecou todos estes aspectos.

\footnotetext{
${ }^{7}$ Dan Miron faz uma introdução à publicação de Fishke der krumer e Massaot Biniamin III (Fishke, o aleijado e Viagens de Benjamim III) em inglês; Schocken Books, Nova York, 1996.
} 
Mêndele sempre reescrevia e aprimorava sua obra. Chegou a escrever para Shólem Aleikhem: "sobre uma obra precisa-se suar, precisa-se trabalhar, polir cada palavra. Lembre-se: polir, polir."

Numa terceira fase de sua atividade faz um retorno pronunciado ao hebraico com obras originais e também traduz para o hebraico o que escrevera em ídiche.

Seus textos, pela qualidade literária e pela resolução dada aos problema linguístico, são considerados por muitos autores o início da moderna literatura hebraica também.

Mêndele criou modelos estereotipados de shtetlekh, baseando-se em suas observações da realidade.

Kabtzansk - Kabtziel em hebraico, baseado em Kapulie, sua cidade natal. Não é a cidade dos pobres, porém, tem a pobreza como mentalidade. À riqueza só se chega por intervenção divina. Não adianta luta nem esforço.

Tuniadevka - Batalon em hebraico: é o lugar da inatividade e da indolência. É o lar de "Benjamin III".

Glupsk - Kissalon em hebraico; é a cidade dos tolos. É dinâmica e tem atividade comercial. É o lar de Fishke der Krumer e onde se passa também a trama de Dos Kleine Mentshele.

Através destas cidades, locomove-se a persona literária Mêndele, o vendedor de livros, exercendo sua profissão e assumindo também funções literárias. Vende tratados de Talmude, Códigos de Comportamentos e Leis, publicações khassidicas, livros de orações, livros populares em ídiche, livros da Haskalá e também amuletos e demais objetos. Desta maneira tem intimidade com os códigos culturais da sociedade judaica, representando o coletivo e o popular, no dizer de Nakhman Meizel ${ }^{8}$.

O pesquisador M. Viner ${ }^{9}$, da literatura russa e judaica, aponta exemplos da influência dos escritores clássicos da literatura mundial como

\footnotetext{
${ }^{8}$ No livro Forgueier un mittzaitler (Precursores e contemporâneos), Editora Ycuf - NY - 1946, pág. 51.

${ }^{9}$ Citação extraída da introdução de Gerald Stillman em sua tradução de $O$ pequeno homenzinho para o inglês, fazendo referência a Tzu der gueshikhte fun der yiddisher literatur in XIX yorhundert, publicado em NY em 1946.
} 
Gogol, Cervantes, Victor Hugo e Dickens. O renomado historiador Dubnov ${ }^{10}$ comparou Dos Vintsh Fingerl a Almas Mortas de Gogol.

Segundo o crítico Baal Makhsheives ${ }^{11}$, todas suas personagens são tipicamente judaicas. Mêndele conseguiu captar dos píntele iid - a quintescência do judeu.

Sh. Niguer ${ }^{12}$, outro importante crítico literário, compara Mêndele a um sofer, escriba, que antes de escrever limpa o corpo em banhos e a alma, em orações, para purificar-se.

\footnotetext{
${ }^{10}$ Volume 11 da coleção de Mêndele - Editora Ferlag Mendele - Varsóvia - 1928, pág 52.

${ }^{11}$ Idem - pág. 134.

12 Idem - pág. 142.
} 


\section{O ÍDICHE DE MÊNDELE}

N. Prilutzki ${ }^{13}$ faz uma análise do ídiche de Mêndele, dizendo que, nas mãos de Mêndele, a língua doméstica e de serviço se transforma numa princesa. Com sua grande sensibilidade linguística, criou uma inteireza orgânica na língua. Seu grande conhecimento do ídiche escrito para as mulheres, desde o religioso ao pseudo literário soma-se aos regionalismos, obtidos graças às suas migrações constantes. Ecos de poesia popular, canções, historinhas ressoam em suas obras, também pródigas em provérbios e expressões idiomáticas. Mêndele purificou a língua, retirando do ídiche germanismos exagerados, inclusive de sintaxe, e limitou também os hebraísmos e eslavismos. Prestou muita atenção na etimologia do ídiche, usando prefixos e sufixos exatos, ao mesmo tempo em que criou neologismos precisos que se somaram ao seu gosto em utilizar sinônimos complementares.

A correção na grafia é mais uma das características da escrita de Mêndele. Foi tomado como modelo na padronização da língua ídiche ocorrida na década de trinta do século passado, em Vilna, pela YIVO, Instituto de Pesquisa Judaica.

\section{O HEBRAICO DE MÊNDELE}

Segundo Hilel Tzaitlin ${ }^{14}$, o hebraico de Mêndele está ligado à Bíblia, à Halakha (leis de comportamento), Talmude, Agadá (lendas), Piut (poesia litúrgica), Moral e Cabalá (mística judaica), enfim, a toda a cultura judaica. Para cada assunto encontra o estilo adequado. Criou um estilo próprio no hebraico, denominado por Bialik de Nussakh Mêndele ${ }^{15}$, do qual ele mesmo foi seguidor. Deu "alma" à língua hebraica transformando-a em uma língua de comunicação, com descrições diversificadas e abrangentes, dotadas de muito movimento, graças à capacidade extraordinária de observar e descrever o povo. Seus personagens são coletivos, possuem características comuns.

\footnotetext{
${ }^{13}$ Idem - pág. 171

${ }^{14}$ Volume 11 da coleção de Mêndele - pág. 172

${ }^{15}$ Segundo Bialik, Mêndele transmitiu a essência do estilo hebraico em todos os tempos, numa síntese linguística elevada.
} 


\section{CONCLUSÕES}

Mêndele valorizava igualmente ambos os idiomas e transitava de um para outro confortavelmente.

A diglossia de Mêndele é considerada um ato artístico e criativo; foi um verdadeiro casamento que gerou gêmeos: o ídiche obteve sua forma hebraica cristalizada e firme. O hebraico, que durante gerações só teve o sabor de vida livresca, renasceu e deleitou-se sob a influência do ídiche.

Mêndele conciliou os dois idiomas colocando num mesmo patamar o ídiche alto germanizado e o baixo ídiche coloquial, bem como o alto hebraico bíblico e o baixo hebraico midráshico rabínico. 


\section{CONSIDERAÇÕES SOBRE O PEQUENO HOMENZINHO}

Neste livro o autor retrata a infância e adolescência miseráveis do personagem central, um menino órfão de pai nos vilarejos judaicos do leste europeu e a posterior ascensão para a riqueza do mesmo, através de cobrança de taxas, abusando e desviando dinheiro da caridade e encaminhando os meninos pobres para o exército russo no lugar dos ricos que pagavam para isso. O livro tem também como narrador o próprio Mêndele, que como membro respeitável da comunidade, é chamado a ouvir o relato e confissão contidos num texto apresentado por um rebe.

É um importante livro na história da literatura ídiche devido a sua compaixão, seu realismo e o uso cuidadoso da língua. Mostra o pior lado da vida judaica do ponto de vista comportamental, junto a referências religiosas importantes e glorificadas.

Max Weinreich, em seu livro Bilder Fun Yidisher Literatur Gueshikhte - (Aspectos da História da Literatura Ídiche) - analisa as várias versões publicadas de Dos Kleine Mentshele.

A primeira edição foi feita em capítulos publicados no jornal $\mathrm{Kol}$ Hamevasser, encarte ídiche do jornal Hameilitz, desde o número 45 de 1864 até o número 9 de 1865.

Nesta edição, ao chegar a Glupsk, a personagem dirige-se ao rabino local em busca de uma benção.

Embora Mêndele tenha transgredido os princípios da Haskalá, de utilizar a língua hebraica, escrevendo em ídiche, o livro teve recepção calorosa. Alguns maskilim, adeptos do iluminismo, empatizaram com a população de baixa classe, os artesãos e os servos. Consideravam-nos não somente pobres, famintos e ignorantes, mas também, brutalizados, manipulados e explorados. Culpavam os líderes khassídicos que tiravam os últimos centavos dessa gente, que era a eles devotada seguindo seus ensinamentos, e entregavam os seus filhos para o serviço militar, poupando assim os seus próprios filhos.

A segunda edição de Dos kleine mentshele, foi igual à primeira e no número 11 de 1865 do jornal Kol hamevasser foi anunciada em propaganda a venda de Dos kleine mentshele, em forma de livro, ao preço de 30 copeques. 
A terceira edição foi realizada ainda em 1865, em Vilna, e reproduziu a anterior.

A quarta edição foi feita também em Vilna, em 1879, porém, totalmente reescrita e mais romanceada; era três vezes e meia maior que a anterior. Mêndele exclui trechos execráveis ao khassidismo e acrescenta idéias feministas, colocadas na voz da rebetzn, a esposa do rebe, o rabino, e sugere reformulações nas novas escolas. Esta versão foi traduzida para o russo.

Mêndele declara em suas memórias que "esta brochura tornou-se a pedra fundamental da nova literatura judaica. Encantei-me pelo ídiche, comprometi-me para sempre e dei-lhe polimento e perfumes até torná-lo uma encantadora princesa".

Em 1907, é publicada em Odessa uma edição especial das obras de Mêndele, sendo esta a quinta edição de $O$ pequeno homenzinho. Esta edição foi revista pelo autor que fez algumas alterações no texto; o romance encontra-se publicado no mesmo volume de Fishke, der Krumer.

Uma republicação da obra de Mêndele foi feita em 1911 por ocasião do seu jubileu.

Em 1928, foi editada em Varsóvia toda a coleção da obra de Mêndele.

Em 1935, o livro foi editado em Moscou, de acordo com a variante de 1879.

Em 1946, toda a coleção foi publicada pelo IKUF em Nova York. Foi esta a versão utilizada para a tradução.

Em 1991 Marvin Zuckerman, Gerald Stillman e Marion Herbst editaram uma tradução para o inglês feita por Gerald Stillman.

A mesma tradução fora publicada em 1956 por Thomas Yoseloff, sob o título de O Parasita.

Em 1977, Shalom Lurya, em tese de doutorado na Universidade Hebraica de Jerusalém, abordou a linguagem figurativa na obra bilíngue de Mêndele. Em 1984, foi publicada sua tradução para o hebraico, Haishon Hakatan, pela Universidade de Haifa.

Em 2003, foi republicada essa tradução para o hebraico, pela Editora Carmel, da Universidade de Haifa. 


\section{EXPRESSÕES IDIOMÁTICAS EM DOS KLEINE MENTSHELE}

Em seu livro auto biográfico Shloime Reb Khaim's, que começou a ser publicado no magazine Der Yid, (O judeu), em 1899, Mêndele relaciona os objetivos que tinha em mente ao escrever:

1 - Introduzir a vida do povo na literatura para que fosse amada por ele.

2 - Ensinar-Ihe o gosto para apreciá-la e transmitir também conhecimentos.

3 - Desenvolver no povo o gosto de falar um idioma de bom nível e que se faça compreender.

Assim, Mêndele usou a caneta como arma para educar seu povo. Não tinha a intenção de apenas diverti-lo.

Mêndele imprimiu neste seu primeiro livro em ídiche uma fluência linguística agradável, pois dominava o idioma com todos seus regionalismos, provérbios e expressões idiomáticas suculentas e multicoloridas.

O significado destas expressões manteve-se inalterado até a atualidade, cerca de um século e meio após. Elas não constituem modismos do autor, pois têm sido encontradas e utilizadas por muitos autores que 0 seguiram.

Segundo Zeev Bloom, Mêndele não expressa o que pensa, mas pensa em como dizer para tornar-se compreensível e passar a sua mensagem. Assim, em digressões, faz uso frequente da expressão: Nit dos bin ikh oissn... , traduzido por "Não é a isto que me refiro...", para voltar ao assunto principal depois de ter abordado aquilo que queria transmitir. É uma maneira de após divagar passando suas idéias, retomar a sequência do texto.

No referido livro, com pouco mais de cem páginas, Mêndele chega a utilizar a expressão sete vezes.

Segue-se uma relação de expressões idiomáticas retiradas do livro, comentadas de forma mais ampla na tradução:

Minha alma quer saber, ouvir e cheirar tudo. Às vezes pode ser muito útil. מיין נשמה וויל אלץ הערן, וויסן, שמעקן

עס קומט דאך טאקע אמאל שטארק צו נוץ

Main neshome vil altz hern, vissn, shmekn. Es kumt dokh take amol shtark tzu nuts 
Deitar-se de comprido e de atravessado (com o sentido de esforçar-se).

זיך לייגן אין דער לענג און אין דער ברייט

Zikh leign in der leng un in der breit.

A lingual ídiche não se envergonha de descrever situações psicológicas por meio de situações fisiológicas; ao contrário, ela festeja o cotidiano e dá inúmeras atribuições às partes do corpo humano.

Permanecer sobre a água (ficar desnorteado).

בלייבן אויפן וואסער

Blaibn oifn vasser

Andar como no dia de ontem (estar confuso).

ארומגיין ווי א נעכטיקער

Arumguein vi a nekhtiker

Onde o cão se encontra enterrado (Lugar misterioso do tesouro).

דרינען ליגט טאקע דער הונט באגראבן

Drinen ligt take der hunt bagrobn

Os judeus não eram muito ligados à criação de animais domésticos excetuando-se aqueles destinados ao próprio consumo. Aos cachorros os judeus não tinham muita afetividade. Eles lembram, porém, misericórdia aos seres vivos em geral e valorizam o lugar onde estão enterrados, como um lugar precioso, que esconde um tesouro.

(Palavras de carinho que sugerem intimidade).

קוצעניו-מוצעניו

Kutzeniu-mutzeniu

Nada com um não (desvalia).

גארנישט מיט א נישט

Gornisht mit a nisht 
Sentar-se sobre alfinetes, (aflição).

זיצן אויף שפילקעם

Zitzn oif shpilkes

O que se encontra no pulmão é o que vem à língua. (exteriorizar o que incomoda).

וואס אויף דער לונג, דאס אויף דער צונג

Vos oif der lung, dos oif der tzung

Furar até a sétima costela. (incomodar).

שטעקן אין דער זיבעטער ריפ

Shtekhn in der zibeter rip

Onde nasce a pimenta preta, longe - longe, no ano negro. (No quinto dos infernos).

ווו דער שווארצער פעפער ואקסט, העט ווייט-ווייט צו אלדיי שווארצער יאר

Vu der shvartzer fefer vaktzt, het vait-vait tzu aldei shvartzer ior

Adequar-se a Deus e aos homens.

טויגן צו גאט און צו לייט

Toign tzu got un tzu lait

Pobreza não é brincadeira.

עפעס א קאטאוועס ארעמקייט

Epes a katoves oremkait

A realidade nas pequenas aldeias da Europa do Leste era difícil e a pobreza era extrema. Porém, a jocosidade estava sempre presente.

Comer todo o coração (martirizar-se).

אפעסן זיך דאס הארץ

Opessn zikh dos hartz 
Uma das partes do corpo humano que ocupa lugar de destaque na cultura do idioma ídiche é o coração, que chega a substituir a alma e o âmago do idioma hebraico. Assim por exemplo: arainkrikhn in hartzn tem o sentido de penetrar no âmago. Hobn hartz tem o sentido de ter misericórdia.

Mastigar a terra (martirizar-se).

קייען די ערד

Kaien di erd

Atuar à moda turca (jogar sujo).

אפטאן אויף טערקיש

Opton oif terkish

Sair dos recipientes (perder o controle).

ארויסגיין פון די כלים

Aroisguein fun di keilim

Barato como sopa de beterraba.

ביליק ווי בארשט

Bilik vi borsht

Voltando à realidade da extrema pobreza das aldeias do leste, tem origem a expressão acima, onde o legume citado era barato e abundava na região.

Água para o trigo sarraceno (valor irrisório).

וואסער אויף קאשע

Vasser oif kashe

Da mesma forma, o trigo sarraceno era barato e havia fartura do mesmo, resultando em grande consumo do produto pelas massas pobres.

Bando branco (grupo de arruaceiros).

ווייסע חברה

Vaisse khevre 
O nome provém de jovens que costumavam vestir-se de roupa branca, a cor das mortalhas e também dos coveiros e preparadores dos corpos a serem enterrados. Essas brincadeiras eram aterradoras.

Como mel misturado a fel (mistura de opostos).

ווי האניק מיט גאל אויסגעמישט

Vi honik mit gal oisguemisht

Como se dá a travessia do gato sobre a água (impossibilidade).

ווי קומט די קאץ איבערן וואסער

Vi kumt di catz ibern vasser

Embora os judeus não fossem ligados à criação de animais domésticos, como já foi mencionado acima, o gato era tido como exemplo de hipocrisia e astúcia.

Banhar-se no conforto (deleitar-se).

זיך באדן אין וווילטאג

Zikh bodn in voiltog

Macarrão, sótão, prateleira (coisas sem sentido).

לאקש, בוידעם, פאלעצע

Loksh, boidem, poletze

Não saber amarrar o rabo de um gato (incompetência).

ניט קענען צובינדן א קאץ דעם עק

Nit kenen tzubindn a catz dem ek

Não avançar, não voar (inverdade).

נישט געשטויגן, נישט געפלויגן

Nisht gueshtoign, nisht guefloign

Ajudará como ventosas a um morto (ineficaz).

עם וועט העלפן ווי א טויטן באנקעם 
Es vet helfn vi a toitn bankes

Houve tempos em que a aplicação de ventosas era considerada curativa e benéfica para certas doenças. Seu uso era muito disseminado. Com a valorização da vida na cultura judaica, esta expressão é usada com muita frequência. Só se perde a esperança quando não há mais vida e é abandonada toda e qualquer tentativa.

Arrastar-se até Boiberik (ir até o fim do mundo).

פאקריכן ביז בויבעריק

Farkrikhn kein Boiberik

Sentir o gosto do paraíso (deleitar-se).

פילן טעם גן עדן

Filn taam gan eiden

Distribuir em mil pratinhos (fazer fofoca).

צעטיילט אויף טויזנט טעלערלעך

Tzeteilt oif toiznt telerlekh

Desde os tempos do patriarca Abraão, a hospitalidade é valorizada dentro do judaísmo. Faz parte da boa hospitalidade oferecer comida distribuída em pratos e bolos em pratinhos. Assim, quando se quer fazer intriga e fofoca, a mesma será distribuída em pratinhos, tornando-a mais simpática.

Longo como a diáspora (interminável).

לאנג ווי דער גלות

Lang vi der goles

No ano 90 da era comum os judeus foram espalhados pelo mundo, migrando de país em país, ou mesmo permanecendo em alguns e integrando-se nos mesmos, sem perder, no entanto, sua identidade. A fundação do Estado de Israel ocorreu somente em 1948. Durante quase dois milênios os judeus permaneceram no exílio, sem um país próprio. Justifica-se assim, a comparação da lonjura de determinado espaço de tempo com a duração da diáspora. 


\section{O PEQUENO HOMENZINHO}

Biografia de Itzkhok Avrom, o Poderoso

Mêndele Moikher Sfórim

Com licença, senhores, e tentem imaginar-me, eu mesmo, quer dizer, Mêndele Moikher Sfórim, como me encontro parado, na época do outono, junto à minha carroça, em algum lugar do caminho, muito pensativo, sem me mexer do lugar. Talvez vocês imaginem que minha carroça atolou na lama e eu estou procurando um jeito de tirá-la? - Não! Isto aconteceu de fato, no ano em curso, $5615^{16}$, que pode ser anotado nas crônicas como um fenômeno, com o seu outono seco e lindo. Parecia pleno verão: quente e claro. O gado pastava nos campos dos quais brotavam densamente grãos tenros e verdes de cereal. Árvores vestiam-se de verde e amarelo, com alguns lugares desbotados, até murchos, parecendo esburacados. Não tinham ainda a intenção de desnudar-se completamente para hibernar, como de costume, toda a próxima estação. Pelo ar, em toda parte, voavam teias de aranha augurando bom tempo, embora o calendário previsse dias nublados e chuvas frias. $O$ calendário que me desculpe, como de costume, não acertou. Uma grande mentira... Porém, não é a isto que me refiro...

Talvez vocês queiram continuar imaginando, que eu estava junto à minha carroça, porque não sabia o caminho? Novamente não! Eu bem sabia que lá, a encruzilhada, à direita, ia dar em *Glupsk e à esquerda, em alguma outra aldeia. Suponham *Kabtzansk. O que então? Simplesmente eu não conseguia decidir por qual caminho ir. Eu tinha

*São cidades imaginárias criadas por Mêndele como artifício literário. Kabtzansk vem de Kabtzn que significa pobre. É a cidade que tem a pobreza como mentalidade. Glupsk é a cidade dos tolos. razões para ir a Glupsk, fazer lá algumas trocas e descarregar mercadorias, bem como velas de cera para Khanuke ${ }^{17}$. Por outro lado, eu tinha razões, também, para ir à feira da outra aldeia. Por isso fiquei parado, nem para cá, nem para lá, como num dilema. Pensativo, observava meu cavalo parado, tranquilo, coçando o pescoço nos arreios e muito contente por ter parado. Eu

\footnotetext{
${ }^{16} 5615$ refere-se à contagem judaica dos anos e corresponde a 1855 na contagem usual.

${ }^{17}$ Khanuke é a festa das luzes.
} 
olhava para ele de tal maneira como se aguardasse uma sugestão de sua parte. Logo tive a idéia de transferir para ele a decisão. Será como ele quiser. Não riam, não riam senhores! Na dúvida, até pessoas inteligentes recorrem a estranhas soluções. Digam-me, peço-lhes, que mal pode haver, neste caso, em dar-se *um tapa na testa ou fazer uma marca na mão? Ou mesmo tirar a sorte com uma moeda ou buscar outros sinais? Um tolo pode ser útil em tais circunstâncias: ele é * A patsh ton in shtern: Tem 0 sentido de lembrar -se. consultado e o seu conselho é seguido. Acontece com muita frequência no mundo que pessoas inteligentes se entregam nas mãos de pessoas tolas e deixam-se conduzir. Eu mesmo conheço vários desses tolos que assim atuam exatamente junto a comerciantes, gente honrada... Porém, não é a isto que me refiro...

Dei um tranco no cavalinho, afrouxei as

${ }^{* *} \mathrm{Nu}$ interjeição que pode significar: então, e daí, donde se conclui...

rédeas e deixei-o livre para conduzir-me aonde quisesse. O cavalo foi para a direita, a caminho de Glupsk. ${ }^{* *} N u$... Pensei com meus botões, fazendo um gesto com a mão, conduza-me, conduza-me. Talvez você tenha razão. Se lhe agrada Glupsk, que seja Glupsk!

*** Vaisse Khevre: no original grupo branco, com 0 sentido de bando de moleques.

Na manhã seguinte, após fazer as orações cheguei a Glupsk e, como é meu costume, fui direto à casa de estudos. Antes que tivesse tempo de olhar ao redor, fui cercado por um bando de judeus maduros e jovens que com saudações efusivas espiaram dentro da carroça e fizeram perguntas, como é o hábito de judeus. ${ }^{* *}$ Um bando de moleques, alunos do Talme-Toire ${ }^{18}$, brincou alegremente com meu cavalo, deram as boas vindas a seu velho conhecido e estavam prontos para arrancar as crinas de seu rabo.No pátio da sinagoga vi grupos de pessoas debatendo algo, conversando, proferindo ditos espirituosos, suspirando e sacudindo a cabeça. Os grupos juntaram-se em seguida, agitando-se, fazendo

${ }^{\star * * *}$ Khogue - festa Cristã. Khag - festa judaica. Denominações semelhantes para abranger outras culturas. ruídos, mexendo com os pés e as mãos para estourar, como bolha de sabão, em pequenos grupos novamente, parece que alguma coisa estava acontecendo. Quando o sino toca é uma ${ }^{* * *}$ festa cristã; eu estava muito

${ }^{18}$ Talme Toire - Escola judaica para meninos pobres, significando o estudo do Pentateuco. 
curioso para descobrir. Afinal eu sou um judeu e minha alma, como se diz, não é de briga; queria inteirar-se de tudo: ouvir, cheirar, como todas as almas judias. Pode vir a ser útil. Às vezes, há judeus que obtêm seu parco sustento por inteirar-se de tudo, metendo o nariz em todo lugar.

Onde há dois judeus um terceiro reclama a sua parte. Como eles dizem: *Hep, Hep... "Estar junto" é uma característica judaica... Porém, não é a isto que me refiro...

Prestei atenção na conversa de um grupo que acabara de se formar perto de mim. Entrou-me no ouvido a seguinte conversa:

- ${ }^{*}$ Ôua, ôua! Bendito seja o Senhor e Sua

*Interjeição depreciativa em relação aos judeus cujo significado é a sigla Hierosolyma est perduta Jerusalém está perdida, em latim - grito de guerra dos Cruzados e mantido como lema por entidades antissemitas.

justiça. Ele ainda era um homem jovem, eu diria com cerca de quarenta anos, ou talvez cinquenta! Ôua, ôua! Que homem! Que homem!

- Por que o senhor se preocupa tanto, e não consegue, coitado, consolar-se, Reb Avremtshe? ${ }^{* * *}$ Que

${ }^{* *}$ Oua - interjeição ídiche de apreciação e contentamento. vá para o inferno, eu juro! O que há de tão importante em sua linhagem? De fato, o quê?

- Para você, lossl, nada é importante! Talvez Reb Avremtshe tenha razão. Ôua! Um homem tão rico! Uma pena! ${ }^{* \star \star \star E u ~ j u r o ! ~}$

- Eis um novo piedoso. Leibtshe Temes! O que disse sua excelência sobre ele antes? O que disse?

- Disse?! O que eu disse, loss!! O que, a propósito?!

- Sem dúvida, o próprio Reb Leibtshe, com sua boquinha pura disse: "Por acaso Itzik Avreml, o

${ }^{* * *} A$ sheine reine kapore - expiação bonita e limpa, significa que a punição é boa e adequada. A expressão "vá para o inferno!" concilia a ideia. mandachuva, pode ser considerado gente? Perdoe-me ele ou não. Ele era um ignorante, um enganador, cruel e, além de tudo, insensível".

- Eu, lossı? Não se tem com quem falar... Um bom dia!

${ }^{* * * *}$ Vi ikh bin a iid: no original, significa como eu sou judeu; trata-se de uma forma de dar veracidade.

- Um bom dia e um bom ano! Venha Reb Avremtshe, vamos à casa de estudos tomar um pouco de aguardente com o zelador. 
- Sabe lossl, um trago agora, talvez não faça mal. Hein? Você foi inteligente, juro, desmascarando o mentiroso. Não nos iludamos; por que ele é tão importante aqui? Ele, que descanse em paz, era um ignorante, um metido, um espoliador.

- Por causa disto gosto do senhor, Reb Avremtshe. O senhor sempre gosta de dizer a verdade.

- Muito dinheiro!... Entupido de dinheiro, que descanse em paz Os judeus se esfalfam berrando no meio de uma roda. Quanto, por exemplo, o senhor Ihe dará?

- Cento e cinquenta mil, acho que Ihe daria com certeza...

- É pouco, pode acrescentar mais, muito mais...

- Que seja, se o senhor quer...

- Temo que, de fato, inteiros trezentos mil.

- O senhor é tolo!... Devem ser justos quinhentos mil.

- Eu sou tolo, e o senhor é um pobretão!

- Vai levar um tapa na bochecha.

- E você vai levar nas duas.

Forma-se uma agitação, uma briga; judeus correm para todos os lados.

- Não, não! Ouvem-se gritos de um grupo. - Esta proposta de casamento não serve para ela. O senhor está fazendo pouco de uma viúva tão rica? Tenho para ela outro pretendente. Este dará certo, com a ajuda de Deus. Sobrou-Ihe uma fortuna, ela tem contrato de casamento riquíssimo e o meu pretendente a tomará, com ambas as mãos, graças ao poder de Deus.

- Juntos, bobão Yokl Grunem! Esganiça outra vozinha. - Eu também tive esta idéia, juntos então. Sejam todos nossas testemunhas!

- Que o diabo carregue o pai de teu pai. Ouve-se outra voz, e o grupo se desfaz como uma bolha de sabão.

Desencilhei meu cavalo, colocando-o voltado para a carroça, entre suas hastes, para alimentá-lo com um saco de farelo de aveia. Comecei então a desempacotar minhas coisas. Mal havia começado a pendurar amuletos de ambos os lados, solidéus brilhantes, alguns pacotes de franjas, 
tateei uma vela, um xale ritual pequeno e outros afins, então, chegou correndo o zelador do Tribunal Judaico num fôlego e disse:

- Oi * guevald, por Deus, Reb Mêndele! A paz esteja convosco, Reb Mêndele. O rabino, que tenha longa vida, pediu-lhe, gentilmente, que se dignasse ir ao seu encontro, imediatamente, imediatamente mesmo, Reb Mêndele.
*Guevald - Significa violência e força, que precedido pela interjeição oi, torna-se um pedido de socorro. 
O fato de o rabino ter tomado conhecimento de minha chegada tão depressa não me surpreendeu. Como Glupsk é uma cidade judaica, logo todos os judeus ficam sabendo de tudo. É só alguém fazer uma observação, para todos ficarem sabendo na rua central e *distribuir a notícia em pratinhos, mais rapidamente que o telégrafo. Surpreendeu-me a presteza com que o rabino mandou me chamar. O que ele poderia querer de mim? Para que enviou o zelador com tanta pressa? Logo me ocorreu a

${ }^{*}$ Tzetrogn oif telerlekh: Forma delicada de espalhar boatos, colocando-os em pratinhos a serem servidos. idéia de um julgamentozinho... Aqui deve haver sarna... Senti uma pontada no coração! Onde já se viu um judeu que não sentisse nos negócios algo nefasto, que poderia vir à tona?... Porém, não é a isto que me refiro...

Fiz uma revisão mental de meus negócios e logo me ocorreu a imagem do sogro da minha filha! Talvez estivesse à espreita para obrigar-me a depositar o dote e encerrar a questão. Ele é uma pessoinha simplória e julga que o que está no contrato de noivado deve ser cumprido, e tudo com que nos comprometemos deve ser liquidado. O tolo não entende que é apenas pró-forma. É só conversa por delicadeza. É preciso falar com a boca cheia para ostentar ao mundo, como faziam nossos pais e avós... Porém, não é a isto que me refiro...

${ }^{* *}$ Kai un shpai no original, significa: mastigue e cuspa. Dá ideia de desvalia, cabendo a tradução quinquiIharia, coisa de pouco valor.

Talvez, pensei, Deus o livre, seja o outro vendedor de livros com o qual, no verão passado, troquei algumas publicações; eu Ihe dei Hagadot, livros de reza, amuletos, dentes de lobos, romances atuais, livros de oração pelos mortos, bagatelas $e^{* *}$ quinquilharias. $E$ ele deu para mim, livros de pedidos, livros de reza para as grandes festas, livros sobre questões

${ }^{* * *} A$ cashe oif a maisse: do aramaico e hebraico no original, significando tudo pode acontecer, nunca se sabe, conota uma indeterminação. religiosas e vários tipos de livros. ${ }^{* * *}$ Quem sabe o que pode ser, talvez tenha percebido que se enganou e quer reconsiderar o preço, exigindo alguma coisa de mim. Que Deus me proteja e me salve de ter negócios com vendedores de livros da região. 
Pode-se *ficar muito irritado por suas queixas e demandas! Porém, não é a isto que me refiro...

Seja qual for o caso, meu coração ficou pesado. Por bem ou por mal, é preciso ir.

Decidi que levaria algumas quinquilharias, algumas miudezas, uma recém lançada Tkhine, livro de Súplicas. Talvez sirva para a rebetzn, a esposa do rabino, e me seja útil... Porém, não é a isto que me refiro...

Estava zangado com meu cavalinho por ter escolhido Glupsk. Roguei-lhe pragas, dando-Ihe um safanão no focinho acompanhado de maldições. Deixei-o, junto com a

${ }^{*}$ Es ken tzezetzt vern di gal, no original, cujo significado é: a vesícula pode explodir, denotando raiva e irritação. carroça, sob a responsabilidade do zelador e saí irritado. Que os garotos de Glupsk the arranquem quantos fios de crina quiserem. É justo, porque ele assim o quis. Se lhe agrada Glupsk, para mim está bom. Não tenho nada com isso.

Logo que pus o pé na casa, ao abrir a porta, o rabino veio ao meu encontro:

- Oi, Reb Mêndele! Seja bem vindo, Reb Mêndele. De fato, só Deus poderia tê-lo trazido, exatamente quando nos é necessário, de fato, muito necessário; querido e sincero Reb Mêndele! Isto é orientado nas alturas, um manifestado milagre dos céus. O senhor agiu com sabedoria vindo exatamente agora, Reb Mêndele.

"Esta sabedoria não se deve a mim, Mêndele, mas a meu cavalinho", - Assim pensei comigo mesmo e, com um sorriso interno, desculpei-me com meu azarado cavalo por meu julgamento. Ao que tudo indicava eu não fora chamado, mas então, o quê?

- Isto eu não conseguia entender. Outros pensariam com certeza que deviam estar ávidos pela mercadoria que eu trazia; porém, eu não era nem criancinha indefesa, nem tinha acabado de sair da casca do ovo, para que não tivesse consciência da situação.

Atenção para uma regra: $O$ mundo consiste em enganação! Quem precisa urgentemente de algo, finge-se de morto, como se a coisa não Ihe servisse absolutamente para nada e assim poder arrematá-la quase de 
graça. Quando, por exemplo, um consumidor necessita de um livro de orações para as grandes festas, mostra interesse por um livro de penitência, de lamentação, ou por um pacote de franjas. Enquanto isto, pega o livro de orações, dá uma rápida olhada recolocando-o no lugar, com desdém e um leve sorriso; por uma ninharia ele até compraria. O mundo todo é um mercado, onde só se procuram pechinchas para levar vantagem. Todos querem que os outros percam, para poderem ganhar. Todos pensam primeiro em si e só depois de serem bem sucedidos e ajudados por Deus, até se sentirem nauseados, pensam, então, em si mesmos... Porém, não é a isto que me refiro...

Pude perceber, pela cara do rabino que ele não queria comprar absolutamente nada de mim, caso contrário não teria se mostrado tão ansioso em me ver. Na verdade ele é um homem justo e correto. *Tomara eu tivesse essa sorte! Mas neste mundo é preciso enganar. Até os anjos precisaram comportar-se como qualquer um diante de Abrão, nosso patriarca, fingindo comer... Porém, não é a isto que me refiro...

*Aza ior zol
ikh hobn-que
eu tenha um
tal ano. Ex-
pressa um
desejo, uma
vontade.

O rabino, que tenha longa vida, convidou-me para seu aposento particular, indicando-me uma cadeira à sua frente. A cadeira provavelmente tinha um pé quebrado, como é de hábito em casa de rabino, eu estava descontrolado por toda a situação, então, subentende-se que devido à pressa, imediatamente ao sentar, caí no chão. Passado o perigo, o rabino fez de conta que não viu e eu também disfarcei.

Pela segunda vez, sentei-me devagar, já sem pressa, cuidando bem dos próprios ossos. O rabino, tenha ele longa vida, pensativo, esfregava a testa com ambas as mãos, cofiava a barba e refletia intensamente. Eu não conseguia entender o significado da situação e fiquei deveras admirado. O que de fato isto significava? Reconsiderando, eu não deveria ficar tão ansioso. Conformei-me em ficar um instante mais velho e assim inteirar-me de tudo. ${ }^{*}$ Foi o que aconteceu; o rabino tirou, em seguida, um maço de papéis do bolso interno do casaco e com um dar de ombros, proferiu, com seriedade, as seguintes palavras:

** Kakh ove,
em hebraico.
Significa a-
conteceu as-
sim como se
relata.

${ }^{* *}$ Kakh ove em hebraico. Significa asim como se relata.

- Reb Mêndele! Este maço de papéis foi-me entregue por Itzkhok Avrom, de abençoada memória, antes de sua morte e com um pedido. Assim 
que ele expirasse, eu deveria ler para todos nossos homens ricos e cumprir, com todas as vírgulas, os detalhes neles contidos. Testamento do morto. Como o senhor sabe, é uma obrigação cumprir o pedido e, logo após seu falecimento, hoje mesmo, convidei todos os ricos e proeminentes da comunidade e li para eles parte dos papéis, deixando o restante para amanhã. Então, o que quero do senhor? Que o senhor, Reb Mêndele, nos honre com sua presença, se Deus assim o permitir, participando da *leitura dos papéis amanhã cedo. Por quê? Amanhã o senhor ficará sabendo, se Deus quiser, após a leitura. Com certeza é correto. Amanhã o senhor já saberá que eu o incomodei por algo importante.

Por ora entrego-Ihe, para ler em sua casa, na intimidade, estas folhas que foram lidas por mim hoje

* Krias Hapapirn, a sintaxe é hebraica e um dos termos está em idiche; krias é leitura de, em hebraico, papirn é papéis em ídiche. Faz um paralelo com a oração principal da liturgia: Krias Shma, para nossos proeminentes, inteirando-se assim de todo o conteúdo, do começo ao fim.

Quando regressei à casa de estudos fui ter com meu cavalinho esfomeado, coitado, olhando para a carroça, com as orelhas empinadas. Então, ${ }^{* *}$ meu herói, meu sábio, digo-lhe cordialmente afagando seu topete. Vamos comer farelo de aveia! Por enquanto, meu herói, é isso que tenho para lhe dar: farelo. Amanhã, se Deus quiser, quando a sua sabedoria for aceita e eu vir o

${ }^{*} \mathrm{O}$ autor se remonta à Hagadá de Pessakh, chamando o cavalo de meu sábio, que entende e sabe formular perguntas. Trata-se da elevação da linguagem com ironia. resultado dela e deparar-me com algum dinheiro, você terá de mim um saco inteiro de aveia pura. Tomo como testemunhas todos os animais que pernoitam no pátio da sinagoga!... 
Numa das folhas que o rabino me entregara, vejo escrito com grandes letras: CONFISSÃO DE ITZKHOK AVROM, para depois começar toda uma história assim:

Nasci, relata Itzkhok Avrom, na aldeia Bezliudef, de pais pobres. De meu pai não me lembro porque ele morreu enquanto eu ainda usava fraldas. Deixou como herança uma mulher fraca, um bocado de crianças e eu, como apêndice, e nada mais. Só tenho lembranças do que comigo se passou na idade de cinco ou seis anos. Conforme me lembro, durante minha juventude, parece que eu não era tido como muito inteligente. Tudo o que eu fazia ou dizia era recebido com muito riso. Nunca me mimaram. Nunca fui beijado, nem acariciado, nem abraçado, como as outras crianças. Quando, às vezes, eu chorava, não era compensado com bolinhos, brinquedinhos ou balinhas, recebia apenas tapas e bofetões. Nunca ouvi a palavra compaixão. Nunca ouvi dizerem, por exemplo: coitado, ele não comeu; coitado, ele está com o rosto inchado. Coitado, ele ainda não descansou. Ele padece e fica jogado. Que lástima, ele passa frio e está só pele e osso. Eu só ouvia dizerem: Vejam só que cara ele tem: as fuças inchadas, os pés vermelhos como beterrabas. Vejam só que comilão, está até babando. Que bela criatura! Já está aprontando: bufa, treme e bate os dentes... Filho de pobre é sempre uma coisa supérflua, a todos incomoda. Em silêncio, desejam-lhe a morte, coitado, ainda na barriga da mãe. Seu nascimento é considerado uma execução. Ainda antes de ver a luz do sol, tem inimigos mortais. E já que se encontra no mundo, é criado de qualquer jeito, sem despertar sentimento de compaixão, nem por parte dos pais. Apenas quando fica gravemente doente, seus pais manifestam um coração humano, que se tornara petrificado devido a preocupações e sofrimento pela amarga pobreza. Só então, transbordam neles puros sentimentos paternais. Avaliam toda vida infeliz de seu pobre filho, coitado, cuja alma pura e querida foi injustamente devastada e atormentada, sem ter tido um momento bom e tranquilo sequer. Eles retratam tudo com cores assustadoras e seu coração clama e chora com lágrimas de sangue. Quando um coração petrificado se abre é como um rio após o degelo, quando se soltam as branquisas. Eu mesmo cheguei a passar por isto nos últimos tempos. 
Parece que carrega, fervilha, agita com uma força terrível. Frequentemente pais pobres lamentam mais por algum de seus filhos, e com muito mais emoção que pais ricos...

Fui criado como um cavalo selvagem na estepe - embrutecido e primitivo. Era capaz de todas feias e agressivas travessuras. Eu tinha o costume de olhar na boca e nos olhos de quem falava. Mamãe quase me matava de pancada arrancando-me pedaços de carne. Uma ocasião em que adoeci e mamãe me tratou com carinho, aproveitei a oportunidade de olhar profundamente em seus olhos, já que ela não me admoestava, e ousei perguntar-Ihe:

- Peço-lhe que me explique, quem é este homenzinho em seus olhos? Mamãe, sorrindo, respondeu:

- Bobinho, este homenzinho é a alma! Ele não existe nos olhos de ninguém, nem dos animais. Apenas nos olhos de judeus.

Esta resposta de minha mãe entrou-me fundo na cabeça, despertando muitas novas e pulsantes idéias. Se uma mãe o diz é porque ela sabe, ela é mãe. Mamãe era muito maior que eu, talvez dez vezes maior. Um dedo seu era como toda minha mão. Por isso aceitei suas palavras como certas, acreditando nelas de todo o coração.

Desde então minha fantasia ficou muito ocupada com o tal homenzinho. É uma curiosidade nova e interessante! Até dormindo o homenzinho não me saía da cabeça, até sonhava com ele, que o estava segurando e brincando com ele. Eu mesmo era um homenzinho e até pulava nos olhos. Em suma, o homenzinho não me saía da cabeça. Eu queria tanto ser um homenzinho também! Uma brincadeira, o homenzinho é a alma; tão grande quanto uma pulga. Parece um nada e é a essência, a vida!... Surgiu-me um pensamento, como detectar tal homenzinho? Comecei a pensar muito sobre $o$ assunto.

Uma vez tive uma brilhante idéia. Enquanto mamãe abaixou a cabeça para tirar uma vasilha do forno, corri até ela como um obcecado - eu mesmo não sei o que me acontecia - e dei, por conta de Deus, um soco com o punho em sua nuca, atrás, para que o homenzinho saísse, por um instante, de seus olhos. Vocês podem imaginar quantas palmadas e beliscões eu levei. 
Além de tudo fiquei o dia inteiro sem comer porque a mamãe, coitada, quebrou a vasilha de mingau com sua testa.

Outra vez recebi uma punição mais severa. Tive uma idéia herética; não me satisfazia acreditar nas palavras da mamãe; queria comprovar, eu mesmo, se um animal tem ou não um homenzinho, uma alma. Então, a minha pessoa aproximou-se de uma vaca na rua, e enquanto examinava seus olhos, ela me agrediu com seus chifres, ferindo-me intensamente. Ainda tenho uma cicatriz profunda do lado esquerdo da face. Todos estes golpes não erradicavam de mim a idéia do homenzinho, ao contrário, a fortaleceram.

Eu estudei num Talme-Toire, que vocês sabem muito bem o que é, poupando-me as explicações. É uma sepultura para enterrar crianças judias pobres, onde suas mentes são mutiladas e removidos todos os contatos com o mundo; é uma fábrica para produzir desocupados, inúteis, pobres almas covardes e infelizes; é um calabouço desolado, um buraco, uma ruína imunda sobre colunas instáveis, como são nas pequenas cidades as escolas TalmeToires - uma vergonha e uma desonra ao próprio nome santo... Como me parece, eu não era um menino bronco. Aos oito anos já estudava o Pentateuco com comentário incluindo Rashi, embora fosse um pouco embotado na língua hebraica. Aparentemente pode-se ser um estudioso e um grande tolo, nada a ver...

Minha mãe costumava chamar-me de "shlimazl", azarado, e na verdade estava muito certa. No Talme-Toire eu era o mais azarado de todos. $O$ rebe ${ }^{19}$, que de jeito nenhum merecia ser assim nomeado, gostava mais de bater do que de um gole amargo. Tinha muito prazer em simplesmente torturar as crianças oprimidas e perseguidas, coitadas, que mesmo sem isto já sofriam bastante e cujos corpos tão mirrados e esquálidos mal sustentavam suas almas. Ele quebrava os já alquebrados ossos, puxava, arrancava magros pedaços de corpo. A melhor porção de seus golpes cabia a mim, o shlimazl. Uma vez, ele ficou tão irritado comigo que quase me matou de tanto bater. Mal saí vivo de suas mãos; precisei parar de frequentar o Talme-Toire. Assim aconteceu:

${ }^{19}$ Rebe - rabino ortodoxo que tem seguidores; significa também professor, preceptor. 
O rebe estivera me explicando uma passagem do Gênese sobre o versículo: "Lemekh disse a suas esposas", assim: Lemekh era um cego. Tuvel-Caim o conduzia e quando viu, ao longe, seu avô Caim, pareceu-lhe um animal (o rebe dissera raposa para explicar melhor). Disse então ao cego que mirasse a raposa; ele mirou e a matou. Quando Lemekh soube que foi de fato seu avô, Caim, que ele matara, começou a golpear-se com desespero, e bateu em seu filho Tuvel-Caim, até a morte. Por esta razão suas esposas se separaram dele. Ele apelou para uma reconciliação: "Vaioimer" - ele disse, "lenoshev" - a suas esposas, "Ode veTzile" - Ada e Tzila, "shimu koill" - ouçam minha voz, "neishei Lemekh" - esposas de Lemekh!...

Num belo dia, apareceu no Talme-Toire, de repente, um tal de alemão barbeado, vindo de Petersburgo. Com ele vieram todos os notáveis para arguir as crianças. Por azar ele mandou-me explicar a porção do Gênesis, justo o bom versículo "Disse Lemekh a suas esposas!" Quando é que tive a oportunidade de falar com alguém, ainda mais com um alemão barbeado? Eu estava agitado e trêmulo como um peixe na água. Zumbia-me nos ouvidos, meu coração palpitava, os cabelos eriçaram-se, nos olhos ficou claro e escuro a um só tempo. Talvez eu não estivesse à altura para contar a comprida história de Lemekh. Estavam todos me intimando: Fale; fale!

O que eu deveria fazer? Fui obrigado a falar. Sem perda de tempo, mas quase perdendo o fôlego, fui explicando devagar:

"Vaioimer" - uma raposa, "Lemekh" - um cego, "lenoshev" - suas esposas separaram-se dele, "Tuvel-Caim" o conduzia, "Ode veTzile" - e ele o matou.

O alemão ficou parado, como que cozido em água fervente. Depois, chamando o rebe, explodiu de raiva:

- O que estou ouvindo aqui? Assim o senhor ensina seus alunos?! Vexame e gozação! $O$ senhor não se ${ }^{*}$ Ressalta a proenvergonha? *Herr Rebe?

O rebe pigarreou, coçou o nariz e balbuciou: núncia gutural do judeu alemão.

- Meus senhores, o menino se assustou. Ele é, realmente, um bom menino. Dou minha palavra!

O alemão, dirigindo-se a mim, falou: 
- Não tenha medo, minha criança. Nada lhe acontecerá. Diga-me o significado de "vaioimer".

Eu, atônito, arregalei os olhos como um boneco de barro e disse direto na cara do alemão:

- "Vaioimer" - raposa! Ele dirigiu-se às esposas...

$\mathrm{O}$ alemão ainda insistiu com a pergunta. $\mathrm{O}$ rabino, coitado, ficou prostrado como se the abrissem feridas, querendo enterrar-se de tanta vergonha. Teve um dia tenebroso, recebeu tudo que merecia. Descarregou em mim seu coração amargurado. Desde então começou a implicar ainda mais comigo e bater sem piedade em mim, até eu não aguentar mais. Adoeci gravemente e parei de frequentar o Talme-Toire. 
Mamãe vivia com grande dificuldade e simplesmente não tinha recursos para passar o dia. Tricotava meias, desplumava penas, acompanhava parturientes, abria a massa do pão ázimo na Páscoa. Costumava trabalhar dia e noite e mal ganhava para comprar a *água para o cereal". As profissões femininas não são valorizadas neste mundo, além de serem sempre mal remuneradas. Afinal o que são as mulheres? Que aparência têm e qual o valor que, desafortunadamente, tem

*Vasser oif ca-
she, significa
água para o
trigo sarrace-
no, o mais
barato cereal
da região. To-
da expressão
indica ganhar
pouco.
a própria judia, mesmo quando é boa dona de casa? Das mulheres, assim, todo o mundo já está convencido, nunca sairá nada de bom: todos seus afazeres não têm nada de concreto. Algo direito, adequado, bom e útil não é para a cabeça da mulher... Da herança do papai, tudo o que sobrou foram duas meninas e um menino, que morreram, pode-se dizer literalmente de fome, um rapaz crescido que se arrastou para algum lugar e está perdido até hoje; não se sabe onde seus ossos foram parar. Junto à mamãe restou uma menina fraca e doente, com a coluna toda arrebentada e eu, o azarado, o shlimazl, que Ihe ficava atravessado na garganta. Eu tinha um apetite voraz, benza Deus! O pouco de comida que eu tomava dela, coitada, não me bastava nem sequer para um dente. Eu costumava pedir comida, comida, qualquer que fosse, contanto que comida. Mamãe, coitada, sofria e não sabia o que fazer comigo. As pessoas costumavam aconselhá-la entregar-me como aprendiz de um artesão, porém, ela meneava a cabeça e falava do fundo do coração.

$$
\text { - Melhor que ele **seja sacrificado do que }
$$

entregá-lo a um trabalhador braçal, um artesão, e envergonhar-me, bem como ao pai, de abençoada memória!... Ele, seu pai, não poderá descansar em paz no

${ }^{* *}$ Novamente a utilização de kapore com o sentido de expiação, neste contexto. túmulo. Isto significa que o filho de Reb Tevil, o melamed ${ }^{20}$, viraria um artesão sujeito às leis da "guilda", dos simplórios. Isto me machuca, só de ouvir. Oh, Senhor do Universo, que meus inimigos não vivam para ver este dia.

\footnotetext{
${ }^{20}$ Professor de escola elementar.
} 
Finalmente, com a ajuda de Deus, mamãe conseguiu empregarme numa loja de armarinhos. Mamãe ficou extremamente satisfeita. Pensou que seu filho já fosse um comerciante.

Seu filho, porém, tornou-se um cachorro! Já thes explico. Minha tarefa era agarrar qualquer transeunte com um pregão e um grito, e arrastá-lo para dentro da loja. Quando passava alguém na rua, atiçavam-me como a um cachorro para que eu saísse correndo e gritasse num só fôlego: Para cá, Páni ${ }^{21}$ ! Lenços de seda, roupa branca, suspensórios, canivetes, galochas americanas, esponjas, sabonete de amêndoa, pomada e demais artigos. No começo foi um pouco desagradável para mim. Como se barra o caminho de quem passa, simplesmente gritando?! É algo estranhamente selvagem! Eu costumava falsear um pouco, encurtando a ladainha e irritando meu patrão com a patroa, que costumavam me insultar, me enlameavam, e atiravam-me na cara que eu comia seu pão e seu sal de graça, embora eu me esfalfasse, trabalhando acima de minhas forças. Fazia todo tipo de

${ }^{*}$ In vasser, in faier - na água e no fogo, em idiche. Significa com muito sacrifício e risco. tarefa, tanto na loja quanto na casa. Servia também como empregado, aos empregados mais antigos. Obedecia-lhes mesmo *correndo riscos, ${ }^{* *}$ com submissão e boa vontade em tudo. Contentavame quando não recebia nenhuma reprimenda, saindo são e salvo de suas mãos. O que dizer quando um empregadinho da outra loja arrancava algum freguês de minhas mãos, eu podia dar adeus à vida. Todos, na loja, caíam sobre mim, uns

** Krikhn zei unter di negl em idiche, com o significado de arrastar-se debaixo de suas unhas, numa atitude servil e de submissão. com a boca, outros com a mão, agredindo-me tanto quanto podiam. Minha mãe e meu pai, Reb Tevil, o melamed, de abençoada memória, também não eram poupados. Agrediam minha mãe e meu pai, até a geração de Abrão, nosso patriarca. Em tais dias, nem se falava sobre comida. Eu jejuava, literalmente, não levando nada à boca. Permitiam-me comer vermes e doenças. Porém, como comer vermes e doenças não é para tripas humanas, eu me deleitava, então, simplesmente jejuando. Tais jejuns ocorriam algumas vezes na semana. Quando me dei conta vi que a situação estava ruim, comecei então a me empenhar mais. Assim que via alguém despontando ao longe e que pudesse

\footnotetext{
${ }^{21}$ Páni-senhor, em polonês.
} 
vir a ser um freguês, saía correndo em sua direção, como um cachorro que se arranca da corrente e anunciando-Ihe, aos berros, todo o rol de mercadorias; puxava-o pela barra do paletó, impedindo-Ihe o caminho. Às vezes apanhava ou levava uma cusparada na cara. Não me importava, como se não fosse comigo. Acostumei-me com o tempo, a gritar; era uma alegria, uma felicidade. Dava-me muita satisfação encaminhar um proprietário polonês para dentro da loja, enchendo-lhe a cabeça. Entre as mercadorias apregoadas eu intercalava berrando, algumas maldições: *Modje Páni Parijeski, se é possível, senhor, que

*O autor dá ênfase à situação fazendo uso do polonês. minhas dores cardíacas, caiam sobre sua cabeça! Pomada, pragas, lepra para o senhor, Páni!

Este tipo de comércio na rua trazia frequentemente conflitos com os empregados das outras lojas, que costumavam também me imitar, agarrando fregueses e gritando. Brigávamos na rua, exatamente como nossos patrões nas lojas, pelas vendas; porém com uma diferença: eles baixando os preços das vendas e nós, empregados, baixando os braços para distribuir tapas e bofetões. E como eu era o menor e o mais fraco, era considerada uma boa ação, os melhores bofetões e os tapas mais ardentes, segundo um critério humanitário, despejá-los sobre mim. Tais dádivas não foram bem vindas por mim e de tais boas ações, segundo um critério humanitário, fui deixando de ser gente.

Uma pessoa não necessita de tais negócios, sem isto também se pode ser "gente", um empregado quer dizer. Mas força e saúde é preciso ter. Eu fui deixando simplesmente de ser "gente". Isto significa que sem força e sem vigor, eu mal parava em pé. Não era brincadeira o que eu suportava! Em casa eu precisava ajudar nos afazeres domésticos; na loja, eu precisava arrumar, varrer, servir a todos, a todos contentar. Para comer eu tinha sofrimentos e amarguras, à minha escolha. Apanhava de estranhos e de conhecidos. O empregado principal esforçava-se para tornar minha vida cada vez mais miserável. Não Ihe agradava que eu dormisse na cozinha, onde costumava entrar sorrateiramente, sempre me provocando. Queria ver-se livre de mim. Eu era como um cisco em seus olhos. Talvez eu tivesse suportado tudo. Não fosse a história do botão. 
Uma vez encontrei jogado na loja um botão de madrepérola que faiscava e brilhava com todas as cores. O botão fascinou meus olhos a tal ponto, que me senti tentado pelo instinto do mal. Meu pensamento voltou-se para minha irmã doente. Decidi dá-lo a ela como presente. No sábado ou feriado ela se ostentaria com ele perante suas amigas. Essa idéia alimentou minha tentação. Peguei o botão e coloquei-o no bolso. $O$ empregado antigo, que observava tudo à distância, veio correndo até mim e gritou:

- Assim, seu moleque, pequeno ladrão, pondo no bolso?! A senhora vê, patroa! As outras coisas que estão faltando também são arte dele! Disse ele com intenção de acobertar seus próprios deslizes, incriminando-me. Deles me lembro, como num sonho. Dava presentinhos à empregada...

Em resumo: tive um amargo e triste fim, espancaram-me bem, enxotando-me em seguida. 
Mamãe recebeu-me novamente como visita numa boa e feliz hora! Não faço a afirmação "numa boa hora" gratuitamente. Mamãe trabalhava, àquele tempo, abrindo a massa do pão ázimo para a Páscoa e devido à sua importância conseguiu-me uma colocação de regador, o que significava molhar a massa que estava sendo aberta, com uma jarra especial de Páscoa. Eu me sentia o próprio ministro das bebidas, devido à importância do meu trabalho. $\mathrm{O}$ emprego fez-me recuperar a auto estima, passando eu a encarar-me com respeito, como uma pessoa à qual é preciso recorrer para obter ajuda necessária. No início foi difícil acertar exatamente a medida da água e por minha culpa algumas bandejas de matze ${ }^{22}$, não saíram boas e adequadas fazendo as pessoas torcerem o nariz. Acabei aprendendo a ponto de fazê-lo automaticamente. Eu mesmo me considerava o melhor despejador de água do mundo, até em Paris não pode haver um melhor do que eu. Dentre as várias pessoas que se alternavam junto ao padeiro, na fabricação das matzes havia um professor de criancinhas. Ele mostrou-se satisfeito com o meu despejar de água, que até me deu um beliscão na bochecha. Mamãe conversava bastante com ele. Um dia me chamou e disse:

- Você vê, Itzkhok Avremtshe, Reb Azriel vai levá-lo consigo, para a escola, para que você se torne seu ajudantezinho!

Para Reb Azriel disse:

- Admiro-me por não ter pensado nisto antes! O pai dele, de abençoada memória, como o senhor sabe, foi mestre de crianças. Que seu filho, que tenha longa vida, siga o mesmo caminho. Porém, é sempre a mesma história, que o senhor *me tenha saúde, se o meu raciocínio se encontra no chão, o que não desejo para o senhor e nem para nenhum judeu. O senhor decerto conheceu meu marido, que o senhor tenha vida longa.

*A utilização de verbos reflexivos, em idiche, torna as expressões mais enfáticas e carinhosas. Novamente a mesma história. Com certeza assim está escrito, que o filho fique também com o "ponteiro ${ }^{23 "}$. Se isto agrada a Deus, também agrada a mim...

\footnotetext{
${ }^{22}$ Matze - Pão ázimo comido durante a Páscoa

${ }^{23}$ Ponteiro é um artefato em forma de mão, em geral de prata, usado para acompanhar a leitura da Bíblia e não danificar o texto.
} 
Que seja com o ponteiro de mestre escola...

Porém, não foi como mamãe pensou; Reb Azriel não precisava de mim como ajudante de professor. Precisava para o berço, para cuidar de seu bebê e para demais coisas afins! A mulher de Reb Azriel tomou-me em suas mãos e me disciplinou. Honrou-me com todos os tipos de afazeres. Eu fui para ela um faz tudo, uma rolha com a qual tampava todos os buracos. Diariamente, pela manhã, era minha obrigação conduzir a cabra ao rebanho, assim como é obrigação do judeu não faltar à reza. Muito raramente Reb Azriel a levava pelos cornos, quer dizer à cabra, ele próprio; eu devia ir atrás empurrando-a com uma vara. Após terminar com a cabra seguia-se um programa de trazer lenha do pátio, juntar gravetos sobre o lixo, jogar fora as águas servidas, varrer a casa e segurar no colo o bebê, com a roupa molhada, que chorava querendo mamar, agitava pés e mãos, ofegava e grunhia e com o perdão da palavra, fungava pelo narizinho. Eu precisava acalmá-lo, inventar brincadeiras, soprar na mão fechada imitando uma corneta, estalar a língua, fazer *"soroke vorone", cantar carneirinho e demais canções infantis. Deus o livre parar um instante! A rebetz $n^{24}$ abria a bocona,

*Nomes de pássaros, em russo, que vão constituir uma alegre brincadeira infantil. despejando sobre mim uma ladainha de maldições e segurando o atiçador para estraçalhar meu cérebro.

Saindo ileso da empreitada, eu corria para recolher as crianças trazendo-as ao $k_{\text {heider }}^{25}$. Aqui começava novo capítulo - deixar as crianças em condições de serem levadas: desde a primeira reza até os 613 preceitos, engraxar os sapatos e as botinhas, arrancá-las molhadas de sob as cobertas, procurar a roupa para vestir, abotoar suas calças, arrancar os fiapos das roupas, soprar peninhas dos solidéus, limpar os narizes, puxá-las à força de casa, empurrando-as para fora... Assim eu ia de casa em casa, reunindo toda a tropa. Então começava a estranha marcha selvagem, despertando a curiosidade. Na frente e na retaguarda, correm pulam, se arrastam meninos em "perfeita formação", as faldas das camisas penduradas fora das calças. Uns vão tristes, cabisbaixos, como para o abate, outros caminham mastigando um pedaço de pão com ovo. Um faz có-có-ri-có e o outro cabritinho, me-mé! Eu

\footnotetext{
${ }^{24}$ Rebetzn é a esposa do Rebe.

${ }^{25}$ Kheider - escola elementar para meninos.
} 
mesmo caminho seguro, no meio, com os bolsos cheios. Levo pendurada no ombro uma sacola com pãezinhos e manteiga, pão untado com gordura de galinha, bicos de pão com rabos de arenques, panelas com pato, coalhadas, queijo, cebola, alho e demais verduras. De ambos os lados seguro pelas mãos, meia dúzia de crianças. Alguns soluçam, outros bufam, uma parte empaca e não quer ir, outra olha para trás. Crianças choram, chamando pelas mães! É uma passeata pelas ruas! Chegando ao kheider, o rebe e o ajudante mais velho assumem todo o grupo de pequenos prisioneiros, começando a açoitálos. Eu precisava alcançar-Ihes as varas e segurar as crianças pelas perninhas. O próprio rebe se dignava a deitá-los e desabotoar-lhes as roupas. Depois que apanhavam, as crianças corriam ao pátio para brincar sobre montes de lixo. Só então eu podia sentar-me para descansar - embalar o berço do *herdeiro do $\operatorname{Reb}^{26}$ Azriel cantando canções de ninar: "sob o berço de Khaikele há um

*Kadish é uma oração antiga da liturgia judaica de louvor e exaltação a Deus, escrita em aramaico; proferida também por ocasião de morte de pais por seus filhos. Assim, onde se encontra o kadish de Reb Azriel a opção de tradução foi: pelo herdeiro.

cabritinho branco", desembaraçar as meadas de linha, recolher as galinhas cacarejando e enxotar o galo com seu harém de cima do telhado e também do sótão.

Algumas horas depois já precisava buscar o almoço das crianças em suas casas; assim, mantinha-me ocupado para cá e para lá até o anoitecer.

Ao anoitecer era chegada a hora de levar para casa o bando de crianças. Meu rebanho de santos corria alegre e pulava. Alguns tinham o olho inchado, outros tinham marcas roxas na face. Para um ardia a orelha e para outro, parte dos cachos laterais fora arrancada. Todos estavam contentes e apressados, era hora em que os rebanhos eram recolhidos dos pastos com as cabras arteiras à frente. Então larguei meus santos e peguei pelos chifres, a cabra de Reb Azriel, o melamed, para levá-la para casa para descansar, poupando-me a dor de cabeça de procurá-la até tarde da noite como era comum acontecer, evitando assim que ela cometesse o grande pecado de pular em jardins alheios.

\footnotetext{
${ }^{26}$ Reb-Tratamento para homem; equivale a senhor.
} 
Com relação a minha alimentação, ficara acertado com Reb Azriel que as famílias da comunidade me manteriam, uma por oito dias, em outra duas semanas ou um mês, como dava. $\mathrm{Na}$ verdade não eram as famílias que serviam, mas suas cozinheiras. Suas cozinheiras, no

*Kugl - Prato típico de festas judaicas, feito de macarrão ou batata; dá pompa à refeição festiva. entanto, não sentiam o compromisso de Reb Azriel e me deixavam passar fome; o que acontecia com frequência. Eu, da minha parte, para não ser grosseiro, fazia tudo que me pediam, embora não estivesse nas condições combinadas. Eu costumava ralar a raiz forte, amolar as facas, limpar e polir os sabáticos candelabros de metal, ir ao magarefe para abater galinhas, ir ao armazém, no lugar da empregada, comprar pimenta, gengibre e canela para o *"kugr" e demais coisas para a casa.

Era a época do feriado de Tishe $B$ 'ov ${ }^{27}$, e eu estava muito ocupado preparando armamentos para meus meninos - espadas de madeira pintadas com suco de amoras pretas e outras tintas estranhas e esperava receber com isso uma boa gratificação. De repente, meu céu ficou nublado, destruindo minhas esperanças. Naquela ocasião, Reb Azriel precisava desferir um golpe mortal, socos mesmo, no filho único de um ricaço. O menino era muito mimado pelos pais. $O$ menino ficou então depauperado e precisou ficar acamado. Os pais fizeram o maior escarcéu e gritavam dizendo que precisavam dar uma lição em Reb Azriel e tomar toda a escola dele. Reb Azriel ficou muito assustado e procurando um caminho para safar-se, jogou a culpa sobre mim, alegando ser a função do ajudante. Ele é, disse Reb Azriel a meu respeito, um grande descarado, um marginal selvagem!

$$
\text { O garoto por sua vez não disse nada, }
$$

** Shlogn Kapores, no original; trata-se de oficiar um ritual, na véspera do dia do perdão, que consiste em girar um galináceo ao redor da cabeça do praticante, passando os seus pecados para a ave. A situação grotesca levou à tradução de desprezo e ridícularização.

estava com muito medo, como de hábito, de contar o que acontecera. Fui considerado, por ambas as partes, culpado. Espancaram-me e expulsaram-me do kheider. Tornei-me o bode expiatório e eu, "shlimazl", o azarado, fui **desprezado e ridicularizado!

\footnotetext{
${ }^{27}$ Tishe B'ov - é o nono dia do mês de Av, onde se recorda a destruição de ambos os templos de Jerusalém.
} 
Bem! - Disse minha mãe resignada, conversando com uma senhora e olhando para mim - É sempre a mesma história: Como se diz, Ester, *"O homem põe e Deus dispõe." Que a senhora fique com saúde. Fiz tudo o que podia para não macular o nome de meu marido no túmulo. Me empenhei de todos os jeitos. Por mais que me esforçasse, foi tudo em vão. Cai tudo com a manteiga para baixo, para deleite dos

*Do ídiche: Der mentsch trakht un Got lakht, significando o homem faz projetos e Deus ri. A rima embeleza 0 ditado em ídiche inimigos dos judeus. Assim como você vê, amiga Ester, já o coloquei em vários lugares. Ele poderia ter virado gente, gente de valor. Deus e o mundo me invejariam. Porém, arrebente-se! Cara amiga, que alguém tenha uma morte estranha e sirva de expiação. Porém, por desaforo, inimigos de Israel, dá **tudo errado. É sempre a mesma história, como se diz. Se o azar não abandona a pessoa, é preciso abaixar a cabeça. Se não se pode por cima, diz o povo um ditado, vai-se por baixo. Até o camponês diz, perdoe-me pela comparação. "Nima riba to i rak riba", em russo, significando: quando não se tem

${ }^{* \star}$ Do original punkt Boiberik - exatamente Boiberik, que é um lugar imaginário sem importância, de onde se sai pela tangente, desviando-se do alvo buscado, que induz ao erro.

peixe, caranguejo peixe é. Você é uma mulher sábia, amiga Ester. Se é para um ofício braçal, que seja. Talvez já esteja determinado no alto que o filho do melamed Tebil seja um trabalhador braçal. Pobre de mim, que desgraça! É sempre a mesma história: ***"O que somos e o que é nossa vida!" Vá questionar o Senhor do Universo!

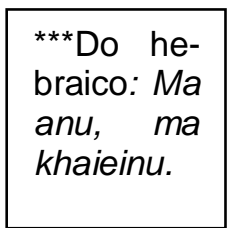

Após alguns dias comecei como aprendiz junto a Leizer, o alfaiate.

Leizer, o alfaiate, era um judeuzinho magro e pálido, muito esperto, agitado como o mercúrio, com todos os maneirismos de um alfaiate um alfaiate até o âmago. Ele podia ser chamado tanto de alfaiate para damas como para cavalheiros, porque ele assumia a responsabilidade de costurar, tanto para homem quanto para mulher, tudo no mundo, até um chapéu também. Porém não sabia nada direito. Sob suas mãos um paletó poderia transformar-se numa camisola, e uma camisola num capote, um capote num vestido, e um vestido numa roupa infantil. Nisto ele era especialista. Calculava 
sempre a metragem necessária para ainda lhe sobrar um bom retalho. No outono, que é a época propícia em que os judeus em família começam a transformar uma roupa em outra, remendando de um membro para outro, ele ficava sobrecarregado de trabalho.

Leizer estava contente consigo mesmo e considerava-se o melhor alfaiate, senão do mundo, pelo menos de Bezliudef, isto porque não sabia quais eram suas falhas. Se alguma vez lhe mostravam um bom trabalho de fora, de Berlim, por exemplo, ele sorria sem se dignar olhar bem, nem examinar como era costurado, nem como era o corte.

- Ps! Ele sorria com desdém, cortando as asas do outro. - Ps! O que há aqui de especial? O que há aqui para admirar? Eu mesmo já refiz este trabalho milhares de vezes. Para tudo é preciso ter sorte! Basta ser de Berlim, khe, khe, para já ser bom.

Leizer tinha uma língua eloquente e rápida. Quando alguém queria descrever um modelo, como ele deveria costurar, não o deixava se expressar. Antecipava-se tomando ele próprio a palavra.

- Eu sei, eu sei - sei - sei! Esteja certo que com a ajuda de Deus, eu lhe farei um trabalho melhor do que o senhor mesmo deseja. Acha que é a primeira vez que faço este tipo de trabalho? Eu sei, esteja convencido, que o senhor ficará satisfeito.

Quando entregava o serviço e o freguês reclamava: aqui the aperta, aqui se amassa, aqui não cai bem, aqui está estreito, Leizer nem queria ouvir e só ficava falando, falando e assolava com palavras:

- Deus o livre! De onde tirou esta idéia? Não está apertado! Não pode estar apertado, nem ousa estar repuxado!? Por favor, estique para o lado. O caimento está perfeito! Uma novidade - está apertado! Não pode estar apertado. O senhor acabou de comer, está empanturrado, por isso Ihe parece estreito. Que eu adoeça no *abrigo de

*Do hebraico hekdesh, lugar institucional da comunidade judaica, com a referida finalidade. Designa também um lugar sujo e desarrumado. desvalidos da região, se sobrou algum tecido. Eu juro por minha fidelidade judaica, o tecido quase não foi suficiente. Mal deu o recheio para a massa da torta. Sobrou uma pequena tira de forro que estou lhe devolvendo. Melhor do que eu fiz, em lugar algum Ihe fariam. O senhor vai se encolher um pouco e se acostumará. Use com saúde! 
$\mathrm{Na}$ hora de pagar começava o regateio. Ficava uma hora amaldiçoando e elogiando até o raiar do dia; relacionou os mínimos detalhes de seu trabalho, quanto Ihe custara, fazia uma conta de alfaiate e chamava como testemunhos, embora sem a presença, o vendedor, o intermediário, até a judia do armarinho. Argumentava com nove medidas de falatório até que lhe acrescentassem dez moedas.

- Bem! Concluía Leizer. Dê pelo menos um pouco de aguardente. Todos seus negócios começavam e se desfaziam com um trago de aguardente. Ele não era, Deus o livre, um bêbado, não vagava pelas ruas, mas sabia beber. "A profissão gosta de um trago" era seu mote. Ele gostava mesmo de bebida, por isso participava das atividades da associação dos alfaiates. Era íntimo do chefe da associação onde se destacava e trabalhava com todo empenho durante qualquer eleição, porque, usualmente, a bebida corria solta. A alma de Leizer pressentia onde obter a gota amarga. Porém, dizer que por um copo ele venderia seu coração e seu juízo e que perderia sua sensibilidade e seu discernimento para diferenciar o bom do mau - Deus o livre - isto não. Não se embriagava, mantinha a lucidez e como todos os outros, conhecia muito bem a verdade. Afogava no copo somente sua ira e seu mau gênio.

Leizer, o alfaiate, recebeu-me bem em seu trabalho e logo começou a ensinar-me o bê-á-bá da profissão, que não era, em absoluto, como se segura a agulha, como se dá um ponto - Não! Ainda era muito cedo para esta honraria, mesmo depois de muito tempo, não ma deram. Leizer começou do início - despejar sua tina com águas servidas, carregar lenha e demais afazeres. Quase o mesmo bê-á-bá que na loja de armarinhos e na escola de Reb Azriel, apenas com algumas mudanças que ficavam bem para um alfaiate, ou seja: ir ao mercado comprar linha pura; esquentar ferros de passar em fornos da própria casa ou de algum vizinho; procurar dez vezes por dia, debaixo da mesa e dos bancos, o dedal ou uma agulha fina; puxar os fios de alinhavos e ir entregar, junto com o patrão, algum trabalho. Como Leizer tinha uma mulher, uma patroa, uma judia eficiente, ela se dedicou muito a mim. Sempre procurava um trabalho para que eu não me sentisse ocioso em nenhum momento. Mamãe ainda não tinha do que se envergonhar de meu trabalho e, por enquanto, meu pai podia ficar sossegado em seu túmulo: seu filho ainda não os envergonhara. Para chegar à agulha havia um longo 
caminho. E quanto a espancar, não se regateava. Às vezes Leizer me batia, às vezes a mulher de Leizer, às vezes, ambos conjuntamente e às vezes os dois, só que de outra maneira. Era assim: Leizer dava alguns tapas na mulher, a Leizerina, e a Leizerina me transmitia fielmente e ainda com juros de saborosos beliscões; podia ser o oposto, Leizerina foi a primeira a bater em Leizer, o quanto pode, com as próprias mãos, e Leizer não suportava sem descarregar em mim o quanto antes possível.

Leizer e a mulher viviam como duas pombas, iguais em tudo. Ambos davam as ordens, ambos diziam a última palavra; ambos temiam um ao outro. Abraçavam-se, beijavam-se; compartilhavam do melhor e do mais bonito - seus tapas...

Não lambi mel na casa de Leizer, o alfaiate. Trabalhava como um asno e apanhava de todos os lados. Eu pensava, naquele tempo, que um aprendiz devia passar por tudo isto. Não será um bom profissional quem não souber esvaziar a tina de águas servidas e quem não apanhar surras flamejantes. Como se sem tapas não se pudesse ensinar.

Espelhei-me no modelo do empregado de Leizer. Um rapaz magro, encurvado, pálido. Seus melhores anos de juventude passou com o alfaiate, fez trabalho estafante e sofreu até chegar ao estágio de segurar uma agulha e remendar. Por isso eu, coitado de mim, recebia com boa vontade todas as surras, sem chorar alto.

Uma vez, antes da Páscoa, o patrão me chamou:

- Itzik Avreml, dê um pulo à lojinha e agarre, que a morte também o agarre, um centavo de linha pura e chuleie, que você também fique chuleado, a parte dianteira deste vestido e depois a parte de trás. Rápido, bastardo.

Lembro-me, como me alegrei pela honra de ficar sentado junto à mesa, segurando uma agulha, como se tivesse sido convidado a um casamento para segurar as hastes do pálio nupcial. Oba! Sentei-me à mesa, em frente ao rapaz pálido, feliz e contente, segurando com ambas as mãos a parte de trás como uma pedra preciosa. $O$ alfaiate cantarolava um trecho do Kol Nidrei ${ }^{28}$, passando logo para um Melekh Elion ${ }^{29}$, em seguida para uma

\footnotetext{
${ }^{28} \mathrm{Kol} \mathrm{Nidrei} \mathrm{-} \mathrm{Oração} \mathrm{imponente,} \mathrm{na} \mathrm{véspera} \mathrm{de} \mathrm{Yom} \mathrm{Kipur,} \mathrm{de} \mathrm{pedido} \mathrm{de} \mathrm{perdão} \mathrm{pelas}$ promessas não cumpridas.

${ }^{29}$ Melekh Elion - Oração de exaltação a Deus.
} 
marcha, balançava a cabeça e tamborilava ritmicamente com a boca. Em seguida disse uma gracinha sobre mim e também sobre o rapaz pálido, mostrando-nos a ponta da língua. Depois cantou com uma voz chorosa a *cerimônia de sentar uma noiva. Logo ele disse rimas como um bufão.

- Rápido Itzik Avreml! Disse ele cantarolando, arrume o pavio do lampião, bastardo! Não durma em serviço! Seu cara enfastiado.

E eu? Uma espetada aqui, uma espetada ali, uma espetada no vestido, uma espetada no dedo. Mas

${ }^{\star}$ Ato tradicional de sentar-se uma noiva no assento nupcial como parte do ritual do casamento judaico. Ela recebe cumprimentos das amigas e parentes, e as abençoa. quem percebe a espetada quando o coração está alegre?...

Logo fui envolvido por uma nuvem de fumaça. Toda casa começou a feder a chamuscado. Procuramos aqui, ali, e finalmente achamos que comigo, o desastrado, estava queimando a parte de trás do vestido, aquela parte de trás que eu chuleara. Isto porque quando arrumei o pavio do lampião uma porção dele caiu! Socorro, uma gritaria, um barulho, uma disparada de tapas, socos e golpes caíram sobre mim em profusão. Levei a minha quota. $\mathrm{O}$ alfaiate tentou fazer da parte de trás a parte da frente, fazer uma manga. Não dava! Ele já recorrera à sobra do baú, esforçava-se, mas, não dava mesmo com esforço, inimigos de Israel, de jeito nenhum. Mesmo que você se mate, mesmo que você adicione manteiga! A parte de trás precisava continuar sendo a parte de trás. De um rabo de porco não dá para fazer um chapéu de pele, um shtreim/ ${ }^{30}$.

- Ouça bem, Itzik Avreml! Disse Leizer - Ouça bem, bastardo, garoto malcriado. Que uma doença tome conta de seus ossos! Não tenho mais forças para bater em você. Quando a patroa voltar do mercado ela certamente esquentará esses seus ossos. Ela tem o mesmo direito que eu e não deixará barato. Porém, isto não é nada se comparado com o que você vai ganhar depois, se eu não aceitar a sua explicação.

Leizer, o alfaiate, logo se concentrou sobre a parte posterior queimada e falou consigo próprio. Por que não um bolso... Do buraco um bolso? E por que não?! Ora, que diferença fará?

\footnotetext{
${ }^{30}$ Shtreiml - chapeu de pele usado por rabinos e judeus devotos aos sábados e dias de festas.
} 
Depois arregalou os olhos sobre mim e deu um berro:

- Cachorro bastardo! Aleluia! Salve! Cachorros que se entendam com você!

Esgueirei-me por baixo da mesa, como um gatinho esperando angustiado meu triste fim.

Esta história trágica aconteceu quarta feira à tarde. Na sexta feira, me lembro como hoje, o patrão mandou-me segui-lo, carregando o vestido para entregá-lo à esposa do arrendatário. Quando a arrendatária deu uma olhada relâmpagos e trovões - um bolso bem atrás, berrou ela:

- O que é isso, senhor alfaiatezinho querido? O que significa isto? Maldito porco, jamais aceitarei este vestido!

- Por favor, senhora! Respondeu o meu Leizer com um sorriso angelical, cortando-Ihe a palavra. Por favor, não grite, Braind!! Que Deus me proteja porque eu the fiz bem! Costurei-Ihe o vestido segundo a última moda. Todas as aristocratas estão usando atualmente bolso pespontado atrás! Só um louco faria hoje bolsos na frente. Senhor do Universo, que eu já fique livre de minha profissão e não precise mais ser alfaiate (assim ele costumava jurar como era o hábito de todos artífices judeus). Como está bonito! É pena que não possa ver com seus próprios olhos esta sétima maravilha! Não apalpe, Braindl, está bom! Vista com saúde. Use com saúde! Rasgue com saúde! Dê uma gorjeta para meu aprendiz. Ele merece, eu juro! Ele, coitado, forçou muito os olhos e trabalhou bastante neste bolso. E eu também mereço um trago!

Leizer era considerado em Bezliudef como um dos melhores alfaiates, que até consultava revistas de moda. $O$ arrendatário era um dos homens mais ricos da cidade e quando as estranhas mulheres de Bezliudef viram

${ }^{*} A \quad$ farshlepte krenk cujo significado é doença crônica, coisa sem fim. sua esposa, a arrendatária, usando um bolso pespontado atrás, começaram a imitá-la. O fato de o meu bolso ter entrado na moda, não me ajudou muito. Leizer temia que eu inventasse novas modas que lhe causariam dor de barriga e, por medo, não quis me dar nenhum trabalho. Entregou-me completamente como presente à sua esposa, reservando-se o direito de espancar-me esporadicamente. De que me serve, dizia ele, esta *doença prolongada, um tal artista! Repetia seu mote costumeiro: Aleluia! Salve! Cachorros que se entendam com você! 
À Leizerina eu causei uma vez um estrago, sem querer; quebrei uma vasilha com ovos e precisei, então, fugir. Depois deste episódio, mamãe me entregou como aprendiz a todo tipo de artífices. A cada semana a um outro. Eu, porém, era um shlimazl, um azarado, e não tive sorte com nenhum. Cada um me apresentava às tarefas domésticas e me atrelava à opressão.

Tive, uma vez, como patrão, um sapateiro, um pobretão alegre que costumava me mandar para lugares sujos arrancar pelos de porco. Bobinho! Ele sempre dizia este mote: Um pelo de porco também é bom. É uma boa ação arrancar de um porco...

Enquanto eu despejava a tina de águas servidas, o alegre pobretão costumava levantar alegre e brincando, cantarolava:

- Dê a honra a Itzinhu! Carregue Itzik Avreminhu e que eu viva bastante para carregar vinho numa bandeja em seu casamento. Continue carregando, Itzinhu. Na sua idade também carreguei água suja!...

Eu gostava deste sapateiro de todo coração. Ele me tratou melhor que todos os outros. Eu teria ficado com ele, e talvez até aprendesse o ofício, porém, ele ficou muito doente. Começou a tossir cada vez mais forte, a cuspir sangue. Ele sofreu muito, trabalhava penosamente, acima de suas forças, para sustentar mulher e filhos. Comer, ele comia apenas sofrimento. Além de uma fatia fina de pão com qualquer coisa por cima, nada chegava a sua boca. $O$ gosto de carne, já esquecera há muito tempo. Em conversa fazia troça: Carne não é coisa de judeu! Eu, louco, sempre me iludia de que teríamos um naco de carne na panela de sábado.

Foi levado num carrinho para um abrigo de desvalidos, onde logo veio a falecer... 
Num belo dia, um dos chantres itinerantes apareceu em Bezliudef e rezou no sábado, acompanhado por um coro. Todo mundo veio correndo das pequenas sinagogas para ouvi-lo. Alguns se comportaram, como se diz, como pessoas simplórias - madrugaram para rezar, tomaram um bom trago e depois vieram ouvir. Houve um aperto terrível. As pessoas empurravam-se sobre as cabeças e eu, no meio da multidão, entrei me empurrando para ouvir o chantre. Como todos os judeus, eu gostava muito de cantar.

O chantre tinha um pequeno cantorzinho, um assobiador, de minha idade. Eu o invejei muito ao vê-lo no púlpito cantando melodiosamente com a mão na bochecha. Eu, com certeza, daria a camisa para ser um cantorzinho como ele. Olhava-o com respeito durante a reza, sentado junto aos outros meninos na antecâmara da sinagoga. Sentia-me anulado diante dele. Ele me parecia o melhor do mundo. Como podia eu comparar-me a ele? Quando o cantorzinho abria a boca, eu ficava olhando dentro dela e se fosse possível, pularia dentro dela, assim como estou. Faria com muito prazer e me deliciaria.

Chegando em casa, tentei imitá-lo. Durante os cânticos soltei a voz e modulei tanto que mamãe teve muita satisfação. Meu objetivo não eram os cânticos, mas imitar o cantorzinho.

Algo cantava dentro de mim. Minha boca cantava sozinha. Eu não conseguia parar por um instante. Já tínhamos acabado de comer o almoço, eu continuava cantando cada vez mais exageradamente. A cantoria transformouse em travessura e eu me esfalfava em estranhas vozes selvagens. Quando mamãe percebeu que eu não queria parar e não a deixaria descansar, após o kug/sabático, deu-me alguns safanões e expulsou-me de casa.

Aonde poderia ir um rapaz no sábado à tarde, senão à sinagoga? He, he! Lá, encontrei toda a turma de moleques, todos bons arteiros. Pensei que só eu imitara o cantorzinho - Não! Todos os outros faziam exatamente como eu o fizera. Estavam todos muito ocupados, um gritava, outro zurrava, um terceiro bramia e um quarto ressoava como um baixo. Um imitava o falsete do cantor, outro fazia caretas levantando a garganta e relinchando. Alguém berrava imitando o chantre e outro soltava a voz como num flauteio. Toda a 
turma subiu, em seguida, à ala feminina, tentando imitar a linda súplica que o chantre fizera durante * "Mi shebeirakh". Lá miava-se, grunhiase, assobiava-se, chiava-se, berrava-se, até que o zelador espirrou água em nós e nos expulsou de modo grosseiro.

$\mathrm{Na}$ verdade, vocês precisam saber, eu tinha uma vozinha fina de fato, uma bela coloratura. Às vezes, eu

*Oração que pede bençãos divinas com finalidades específicas. acompanhava Leizer, o alfaiate, na cerimônia de sentar uma noiva, ou ajudá-lo em "Melekh Elion". Leizer costumava me encarar, dizendo com um sorriso e denotando grande satisfação: Bem, bastardinho! Continue, continue! Até que seu pai se revire no túmulo, bastardo!

Ocorreu-me então pedir a mamãe que me entregasse ao chantre. Juntei-me a minha mãe, e amolei-a tanto, tanto, até que ela acabou me levando ao chantre. A pobre e sofrida viúva, coitada, já se alegrava por ver-se livre de um traste como eu. Quando o chantre me mandou dar um agudo e disse que me aceitava, fiquei tão feliz como se fosse o dono do mundo. Não consigo descrever o que sentia no coração. Mamãe também ficou aparentemente muito, muito contente com isto, de fato muito contente. Eu a ouvi conversando com uma judia conhecida, dizendo para ela.

- A mesma história, Ester. Que você tenha uma vida longa. Como uma pessoa pode decidir o futuro de outra? Quebre sua cabeça, inimigo de Israel. Empenhe-se até sair da própria pele, Ester, você nada consegue. Como se diz, Ester, se Deus, ${ }^{* *}$ seja louvado, eleva uma pessoa não se

${ }^{* *}$ HaShem itvarekh - no original em hebraico. $\mathrm{O}$ autor faz uso de expressões hebraicas para elevar o padrão da linguagem. percebe como ela conseguiu. Falo em relação ao meu órfão. Novamente a mesma história. As pessoas diziam, um ofício, uma profissão. Que seja! O que teria sido dele? Porém, Deus em sua infinita bondade mostrou que não era como as pessoas diziam, não Ester, mas justo um chantre!... Agradeço e louvo ao Senhor, seja ele abençoado. Meu órfão já está arranjado, já é gente. Oxalá para todos meus amigos!

Eu nem mereço tal sorte. Aí, evidentemente, trata-se do mérito dos antepassados que se empenharam.

Com o chantre vaguei pelo mundo mais de meio ano. Eu, o azarado, também passei mal com ele. Pior do que todos os outros cantores. Eu 
mesmo *me enrolei. Era costume quando o chantre rezava em alguma localidade, os meninos cantores observarem o público e ver se seu canto e sua reza agradavam, o que se dizia a respeito de sua voz e da pronúncia do hebraico. Quando em casa o chantre chamava alguém pelo nome, fazendo um sinal, significava: E daí, ficaram satisfeitos? Quase sempre, porém, a sorte recaia sobre mim, por desaforo. Talvez porque os demais cantores escapuliam logo após a reza e viravam poeira.

Assim que ele chamou meu nome, Avremke, fazendo o sinal conhecido, soltei o verbo. Eu, que não conhecia subterfúgios, falei diretamente. Chantre, eles riram do senhor, riram muito. Então ele me pegava pela orelha, torcia e torcia, puxava e puxava, que

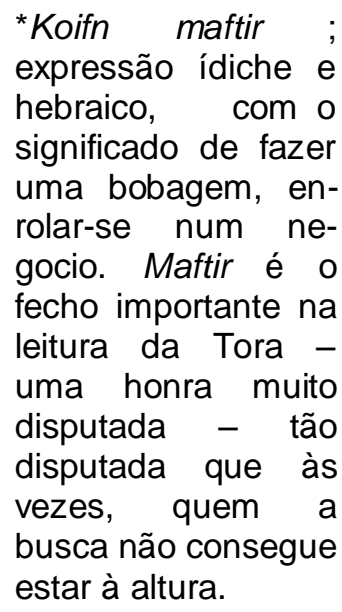

eu Ihes digo que os golpes da mulher do alfaiate pareciam brincadeira diante disto. Uma vez rezamos numa cidadezinha; a porção semanal era "Shekolim ${ }^{31}$," sobre o senso judaico. O chantre preparou-se muito; queria agradar para obter uma colocação estável. À noite, ao final do sábado, reuniu-se um grupo grande de pessoas da cidade. Bebiam ponche e vinho alegremente. Foi uma alegre despedida do sábado. O chantre queria fazer graça, ser gentil com as pessoas, embora se queixasse de dor de garganta, que se resfriara e precisava cuidar de seu instrumento de trabalho. Como de hábito vacilou, vacilou e acabou atendendo o público, como é o costume, dizendo sobre o profeta Elias e cantou uma canção folclórica alegre. O chantre achou necessário mandar mais alguma coisa e chamou: Avremke! Então abri a boca e disse: "Chantre, eles riram do senhor"! Falei em voz alta e alegre devido à bebida que tinha na cabeça. O chantre, coitado, enfureceu-se, ficou vermelho e estufado como um peru, o rosto contorceu-se numa careta. Todo público ficou atônito, de olhos esbugalhados. Julguei que o chantre não estava acreditando. Falante eu estava devido ao pouco de ponche, soltei minha doce linguinha e comecei a jurar: "Palavra de judeu, chantre, riram do senhor. Estas pessoas caçoaram muito... Este que bebe e cochicha com o senhor, juro que riu durante a oração

\footnotetext{
${ }^{31}$ Shekolim - refere-se a uma porção semanal da bíblia que aborda o pagamento de meio shekel (siclo - moeda da época), através do qual fazia-se o censo judaico.
} 
da Kedushe ${ }^{32}$, chegaram até a chamá-lo de falastrão, que eu nem sei o que significa, se é peru ou pato..." O chantre mordeu os lábios e fez de conta que estava rindo e disse ao público que eu era um bobo, um tonto e não sabia quem me havia moldado. Além destas qualidades enunciadas eu devia estar um pouco embriagado também. Que ele tolerava tal estrupício devido à voz. As pessoas consideraram toda situação desagradável e debandaram contrariados. Vocês podem imaginar o que me coube depois. O chantre me mostrou que Deus nós temos, e o que de um pouco de ponche, pode resultar. Continuei peregrinando com o khazn e me arrastando através de muitas cidadezinhas judaicas até chegarmos a Tzvuetshitz ${ }^{33}$, em um sábado cuja porção semanal era Nakhamu ${ }^{34}$, em que clemência e consolação são solicitadas após o luto de Tishe B'ov, onde ele pretendia ser contratado. Para isso moveu céus e terras e utilizou todos seus instrumentos. Os diretores the pediram que ficasse para as grandes festas e depois acertariam tudo, se Deus quiser. Neste meio tempo fiz amizade com os moleques do local, tornando-me um deles, " ${ }^{*}$ Shoifer - Chigracas a fre de animal graças a Deus. Isto significa que quando calhou de kosher, sopra-

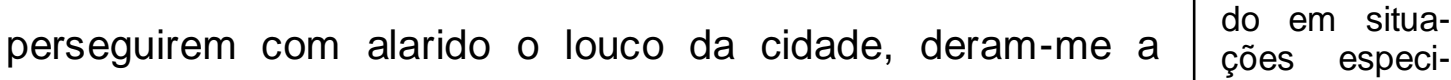
dianteira, ou quando queriam aprontar com alguém faziam de mim um capacho e quando, uma vez, fomos bem sucedidos ais visando levar 0 som aos céus. ao roubar do armário do zelador o * shoifer honraram-me com o primeiro toque. Estava começando até a me sentir muito bem, de fato; mas o que adianta tudo isto, quando a sorte não ajuda?! Ouçam meu desfecho com o khazn! Para o Ano Novo vocês podem imaginar como ele se esfalfou, coitado. Ele trabalhou, como se diz, com todas as comportas, com todas as possibilidades. Enrolou cada palavra, cerca de dez vezes acima e abaixo, explicando com o dedo. Passou do som natural da boca para o falsete, de repente - haidi-di-di pra cá, haidi-di-di pra lá, quase subindo pelas paredes. O baixo ficou rouco devido ao tom, cada trecho com novo tom, e mais uma vez latum-dum-dum-dum!! De novo latundum-dum-dum!! Ele se esvaia em suor, limpando-se continuamente com o lenço que não the saia da mão, e que ele girava no ar. A voz já não servia para flauteio que precisava suplantar o baixo. A cada sinal do khazn,

\footnotetext{
${ }^{32}$ Kedushe - santidade. É a reza na qual se exalta a santidade divina.

${ }^{33}$ Tzvuetshitz - cidade dos fingidos.

${ }^{34}$ Nakhamu - significa consolai. É o sábado que segue as três semanas de luto que incluem

o Tishe B'ov e onde se solicita clemência e consolação.
} 
assobio ou grito, eu, coitado precisava dar um grito, pai-zi-nho! Ou um longo tratata-ti... Até então... Enfim, *trabalhamos, nos esforçamos.

$\mathrm{Na}$ sinagoga rezava um jovem senhor, um milionário. Era um pouco moderno, gordo, saudável, um pouco palhaço e muito boa pessoa. Gostava de fazer-se de bobo com as crianças e detestava pavorosamente os trejeitos horrorosos do khazn. Quando o khazn se alongou em "Oto zoikher" que faz parte das dezoito bênçãos da reza

*Zikh guerisn oif vos di velt shteit - arrastar-se sobre os suportes do mundo, cujo significado é esforçar-se intensamente.

vespertina, estendendo-se como se fosse o caminho do correio, a diligência postal, lançando trechos modulados de "Veneimar", a la "Pó Molodetzki", chegou-se até mim, como um gatinho, o palhaço milionário com um rostinho sério e perguntou:

- Diga-me pequeno, você sabe fazer um biquinho com a boca?

E logo em seu lábio inferior ficou pronto um biquinho, tão grande e tão vermelho que eu explodi numa gargalhada, mas neste momento, justo, o khazn já modulara um "Veneimar"... e aguardava que eu fizesse trata-ta-ti! Quando o público percebeu que o khazn ficara calado como que estrangulado, começou a bater sobre a mesa. O khazn encarou-me com raiva como se eu 0 tivesse assaltado ou não quisesse devolver o que era seu por direito. Seus olhos flamejavam e seu rosto estava vermelho como um cozido de cenoura refogado. O baixo virou a cabeça em minha direção com um berro, como uma vaca para seu bezerro, significando, responda com seu tratata-ti! Logo que pus o dedo no pescoço para emitir o som, o ricaço diante de mim, fez novamente um biquinho, e eu sem querer, de repente, explodi numa gargalhada sonora e estridente!

O khazn confuso, embaraçado e aturdido, ficou fora de si, saiu do caminho reto, saltou trechos do **"Shmonessrel", cometendo vários erros.

** Shmonessrei: Significa dezoito. Trata-se de uma oração com dezoito bênçãos, na verdade dezenove, proferida em cada reza duas vezes; uma vez silenciosamente e uma segunda vez pelo condutor da reza em voz alta. Permanece-se em pé, em posição de sentido. O público, de todos os lados, admirado, pronunciouse com um: "ai, ai, ai”. Batia palmas e martelava sobre as mesas. As mulheres na ala feminina se assustaram muito e começaram a gritar num só fôlego: Fogo!... Os homens também se assustaram e começaram a se empurrar e 
correr em direção à saída. Enfim, instalou-se uma reza agitada, um pandemônio! O público ficou terrivelmente insatisfeito

Na manhã seguinte, depois do ano novo, o khazn me expulsou. Envergonhado e abatido ele deixou a cidade, coitado, vagando para outro lugar.

Eu, shlimazl, sobrevivi ${ }^{*}$ completamente confuso, em Tzvuetshitz.

*Vi oifn vasser, em ídiche no original, equivale a sobre a água. Seu significado é estar completamente confuso e estarrecido. 


\section{VIII}

Durante o ano novo, comi na casa de um judeu de Tzvuetshitz, de difícil definição: não era nem devoto, nem moderno, tanto para cá como para lá. Nem para cá, nem para lá, melhor dizendo. Não se vestia à moda moderna, nem à antiga. Como se diz: nem de carne, nem de leite, era um meio assado, enfim um tipo especial de judeu. Encontrei depois, no mundo, vários tipos semelhantes. Eu não conseguia entendê-los, nem conceituá-los... Como fiquei solitário, vagando como um carneirinho sozinho, sem ter com que passar o dia, resolvi dirigir-me ao referido judeu. Contei-Ihe toda minha desgraça, todo infortúnio que me atingira. Ele não era por natureza uma pessoa ruim. Calado: uma palavra - uma moeda de ouro. Ouviu-me calado, alisando os bigodes. Distraidamente acenou com a mão para que eu ficasse, e ordenou em casa que me dessem comida. À noite, por volta de dez ou onze horas, quando não havia viv'alma na rua, nem um cão danado, e fora não dava para ver nada, levou-me aos confins da cidade, numa ruazinha isolada onde só se ouvia o rumor das árvores sacudidas pelo vento, como o maço de espécies vegetais na festa de Sukes $^{35}$, a festa das cabanas. Também se ouvia o sussurro de algumas folhas remanescentes de uma arvorezinha e o som de uma chuvinha de outono que pingava sobre folhas caídas e sobre capim seco de todas as espécies. Quando o vento amainou por um instante, foi possível ouvir de longe o rumor, em algum lugar, de um moinho e o barulho e o clamor de fortes correntezas. Quando o vento voltou a soprar trouxe consigo, no início, ruídos da cidade, sons indefinidos e misturados: um canto de galo, um mugido de vaca, o arrastar de um portão vai e vem, o rumor de um carroceiro em jornada e o latido de um cão doméstico. Provavelmente naquela ruela não havia judeus, pois ela era margeada de hortas e árvores, e o caminho era coberto por folhas secas. O meu judeu precisaria tatear o caminho para que no meio da rua não se chocasse com uma vaca, ou tropeçasse em degraus quebrados diante de cada porta. Meu judeu continuava a andar sem me dirigir uma palavra sequer, até que chegamos a um quintalzinho e entramos numa casa baixa, não

\footnotetext{
${ }^{35}$ Sukes - festa das cabanas, que tem a duração de uma semana iniciando-se no dia 15 de tishrei e durante a qual se come em seu interior. Tem uma conotação de festa agrícola e representa a integração de todos os tipos de judeus.
} 
grande. Numa pequena ante sala brilhava uma luz; lá, o meu judeu tirou sua capa e entrou numa outra sala. A mim mandou aguardar aqui na ante sala. Fiquei parado atrás da porta fechada, de onde ouvi o seguinte dito: "Até aqui reza-se no "Shabes Godl"

Assim terminou a última folha que o rabino me dera para ler. Como era um pouco tarde, rezei o $S_{m} a^{36} \mathrm{e}$ me deitei no banco da casa de estudos para dormir.

*Shabes Godl é o sábado que antecede a Páscoa.

${ }^{36}$ Shmá - ouça em hebraico, oração proferida várias vezes ao dia e considerada a profissão de fé judaica. 


\section{IX}

Mal acabei de rezar pela manhã, comi qualquer coisa rapidamente, deixando o cavalo e a carroça aos cuidados do zelador e apressei-me para a casa do rabino.

Encontrei em sua casa um bom grupo de pessoas, benza Deus juízes e ricaços. O próprio rabino ainda não chegara. Estavam todos calados e pensativos. Ricaços estão sempre pensativos, preocupados e olham para os outros com cara de melancólicos, de modo que se sente um frio na barriga e uma vontade de ir embora e não os ver mais. Eu não sei, de jeito nenhum, por que se se tem dinheiro, o que há para pensar, para preocupar e fazer uma expressão tão séria? Me parece que não é tão difícil contar dinheiro. Não é preciso ter altos pensamentos. Pode-se, me parece, ter baús de dinheiro e encarar os outros de igual para igual, sem fazer cara feia. Porém, nada... Isto, porém, não é a isto que me refiro...

- Por que o senhor suspira tanto, Reb Khone! - Um ricaço perguntou ao outro.

- Estou suspirando, Reb Berish, por nossa perda. Itzkhok Avrom era uma pessoa muito útil. Tínhamos nele um amigo, um ativista, uma pessoa discreta. Morreu muito cedo. Deveria ter vivido mais alguns anos. Que perda! Podemos todos suspirar por tão grande perda. Foi uma perda para a cidade a morte de Itzkhok Avrom, e para todos nós, penso eu.

- É bem verdade, Reb Khone - responderam todos muito pensativos.

- Ainda tenho um casamento, hoje - disse um membro do tribunal. - Devo oficiar a cerimônia.

- Eu estou faminto - interveio outro membro. Gostaria de comer alguma coisa. Hoje só ingeri um copo de chicória na hora do café.

- Minhas hemorróidas estão me matando! - manifestou-se um terceiro membro. - Eu Ihes rogo, o que vocês sugerem para amenizar? Dizem que cozido de cenoura é bom. Eu sei lá. Eu só costumava ser adepto de ameixas cozidas com folhas purgativas. 
- O melhor remédio para hemorróidas - manifestaram-se os dois primeiros interlocutores - é ignorá-las, não fazendo nada. Este é o segredo que recebemos de nossos pais...

Eu estava aflito, sentado sobre brasas, contando os minutos para que o rabino chegasse e eu pudesse saber o fim da história e para quê eu era tão necessário aqui. Cada instante era muito demorado que cansei de esperar. Deus ajudou e o rabino entrou com um cenho franzido denotando que dentro de sua cabeça havia muitos pensamentos. Desculpou-se por ter feito o público esperar. Ele estivera ocupado numa questão difícil e vital.

- Estão todos aqui, meus senhores? Perguntou o rabino, tomando assento em sua poltrona.

- Todos, rabino, todos; apenas um Reb Faivish falta para o quorum.

- Reb Faivish está hoje... como vou dizer? Em clima de festa. Como membro da santa sociedade fúnebre, me refiro a Reb Faivish, receberá um bom pagamento pelo sepultamento de Itzkhok Avrom por parte de seus herdeiros; julgo eu - manifestou-se um dos ricaços com uma cara muito feia, azeda como o vinagre e que tinha fel na boca.

- Peço-lhes novamente perdão, senhores - Disse o rabino, dirigindo-se ao público - por dispender seu tempo com esta história. Sei que são todos pessoas ocupadas, cada um com seus negócios, e com certeza, não têm tempo! Porém, o que devo fazer? É uma obrigação cumprir o testamento de um morto. Ele, de saudosa memória, exigiu isto de mim, e merece, por direito, que se cumpra seu pedido. Vocês entenderão o porquê ao final. Senhores, peço-Ihes perdão cem vezes.

- Tudo bem! Tudo bem! - Disseram todos os ricaços - Ao contrário, rabino, a história nos agrada muito. Não nos cansaríamos de ouvi-la até o final, nem que levasse um dia e uma noite, tanto ela nos agrada. Além de tudo, Itzkhok Avrom merece de nós que lhe dediquemos um tempo para suas descrições. Deve haver um propósito. Não nos arrependeremos por tê-lo ouvido.

O rabino, que tenha longa vida, pegou um maço de papéis e, após pigarrear um pouco, disse: 
- Paramos ontem, parece-me, no trecho em que o autor ouvira uma fala do aposento contíguo.

- Sim, aí, sim aí!

Confirmei o que o rebe dissera e devolvi-lhe os manuscritos que me dera na véspera.

- Bem, bem, Reb Mêndele! O rabino apresentou-me, gentilmente, aos demais presentes:

- Nossa visita, prezados senhores, é Reb Mêndele... O nosso Reb Mêndele. Eu fiz com que ele se desse ao trabalho por mim. Ele concordou em participar, pois será útil no caso. Agora senhores, ouçam, por favor, o que vem a seguir.

Como é de hábito, as pessoas acomodaram-se ruidosamente arrastando cadeiras, pigarreando, assoando o nariz e tossindo. O rabino, que tenha longa vida, aguardou cofiando a barba e olhando seriamente nos papéis, até que o público sossegasse. 
O rabino recomeça a leitura do texto:

- Atrás da porta fechada, ouvi a seguinte conversa:

- Boa noite, Herr Gutman!

- Willkomenn ${ }^{37}$, Herr Jakobsohn. Que visita! Há três semanas não o vejo. Qual a razão de sua visita? Herr Jacobsohn.

- Prezado Herr Gutman, como eu poderia? O senhor sabe perfeitamente que estamos na época das grandes festas e os judeus locais estão cada vez mais fanáticos. O senhor conhece minha situação. Como dependo deles, o que aconteceria se me vissem aqui...

- O senhor tem toda a razão, Herr Jacobsohn. Depende deles e o senhor tem família.

- Já terminou seu trabalho, Herr Gutman!

* A palavra idiche para livro é bukh; quando o livro versa sobre religião usa-se a forma hebraica sêfer, elevando o padrão linguístico.

- Oh, sim! *O livro saiu bom. É um livro muito útil. É uma pena haver poucos leitores de hebraico entre nós. Um livro muito necessário.

- Melhor dizendo, Herr Gutman, o senhor não recebe por seu trabalho e ainda precisa, frequentemente, passar privações, e ser menosprezado e perseguido, e isto tudo sem ganhar.

- Acredite-me, Herr Jacobsohn. O escritor, o poeta não almeja qualquer recompensa, além de ser entendido. Perseguições, desprezos, escassez, estimulam seu espírito e o incentivam a trabalhar. Desprezo e desonra são gratificantes. Sofrer pela verdade, pela honestidade, não significa sofrer. Sofrer é bajular, é ser hipócrita, é humilhar-se, é renegar, é submeter consciência e raciocínio. O senhor pensa que ser adulador e falso é tarefa fácil? Deus o livre! É tão difícil como ser um ladrão. O adulador, o hipócrita, o falso precisam sempre estar atentos, sempre cuidar-se como o ladrão. O senhor acredita que todos os meus oponentes, aqueles que me perseguem, os religiosos, são piedosos e felizes? Oh, não, não! Parte deles hostilizam-me por desespero e inveja. É bem simples; eles se sentem vazios, ignorantes e inúteis. Irritam-se por deparar-se com pessoas que raciocinam, que os conhecem bem,

\footnotetext{
${ }^{37}$ Willkomenn, em alemão, bem vindo.
} 
capazes de perscrutá-los com os olhos abertos. Temem olhos abertos como os morcegos temem os raios do sol radiante.

- De fato, Herr Gutman, por sua habilidade e otimismo, o senhor é uma pessoa afortunada e invejável. Na verdade, sabe qual é a razão real de minha visita? O senhor já me disse várias vezes necessitar de um jovem mensageiro. Agora encontrei um e o trouxe. Ele parece ser honesto, porém, um pouco tolo, não refinado.

Entendi quase toda a conversa, porém não sua essência, seu significado. Isto não era para minha cabeça. Eu só entendia as palavras. Parte das palavras era de nossa língua, o ídiche, e as poucas palavras alemãs eu podia concluir de minha peregrinação com o khazn. Ele próprio gostava de inserir, em suas conversas, quando Ihe convinha, alguma expressão alemã. Onde a gente simples punha $o^{38}$, ele punha $a$. Gabava-se de cantar seguindo a partitura e também formando um coral... O Talme Toire também me ensinou um pouco de alemão ao estudar o Pentateuco com a tradução para o ídiche, antiquado e germanizado, como por exemplo: "veolto" - e uma neblina, "vessadó libkhem" - sustentem seu coração para não desfalecer, "iarkhe" refiro-me a você, "mekhashef" - descubram, "bohu" - sobre a imundície, "bein hamishpotim" - entre os domínios, "utekhalela" - e você a profanou "koimemies" - altaneiramente, e demais traduções como estas. Na loja de armarinhos também captei palavras alemãs com os empregados, no seu empenho de agradar os fregueses, esparramavam-se em alemão, a língua da cultura: "Meu Herr, veja esta mercadoria! Juro que não pedi caro. Pedi mais barato que uma bagatela. Meu Herr não se arrependerá." Além de tudo, todos os judeus entendem alemão. É a origem de sua língua materna...

A porta abriu-se, de repente, e eu fui convidado para o outro aposento. Vi que o meu judeu estava sem chapéu. $\mathrm{O}$ alemão tomou-me pela mão e me disse cordialmente:

- E então, caro jovem! Quer empregar-se em minha casa? Comigo você não terá um trabalho árduo. Desempenhará tarefas comuns e entregará recados.

\footnotetext{
${ }^{38}$ Ó e $A-$ a referência é feita aos diacríticos que representam as vogais hebraicas: patakhpara A e kamatz - para Ó.
} 
Arregalei um par de olhos fitando-o tão estupidamente, a ponto de o alemão não pode conter seu sorriso. Apesar disto, logo gostei dele. Sua expressão denotava tanta bondade e ele conversou comigo tão amigavelmente, não como todos os outros: o alfaiate e o khazn, por exemplo, e até mesmo como minha mãe. Ele me encarava com tanta serenidade, com bom semblante que logo me senti atraído por ele. Levei a mão ao meu boné, que costumava usar tanto no inverno como no verão, nas grandes canículas quando até ficava descalço. Levantei-o um pouco, à frente, depois virei para um lado e para outro, puxei-o para baixo e enquanto enrolava os cachos laterais com a outra mão, cocei a nuca. Não sabia o que fazer nem com a cabeça, nem com o boné. Finalmente criei coragem e tirei-o, com a graça de Deus, da cabeça, rapidamente. Senti então um ventinho fresco na cabeça descoberta como se estivesse tendo o cabelo cortado. A todo instante sentia necessidade de apalpar a cabeça. Parecia-me estranhamente selvagem, como que no banho.

- Bem, minha querida criança - falou o alemão colocando a mão sobre meu ombro - Você é um bom rapaz! Como você se chama?

Eu sentia-me aturdido, exatamente, como na ocasião em que fui arguido no Talme Toire pelo outro alemão. Fiquei de boca aberta, esbugalhei um par de olhos como um tonto, como um perfeito "golem 39 " de barro.

- Como você se chama? - O alemão voltou a perguntar.

- Eu lá sei?!

- Se você não sabe, quem poderá saber?

- Minha mãe - respondi - costumava chamar-me de Itzkhok Avremtshe, o professor do Talme Toire - Itze Avremele, o alfaiate - bastardo Itzik Avreml, o sapateiro, enquanto eu despejava as águas sujas - Itzinhu Avreminhu e o khazn - Avremke. Então como saberei meu nome?

- Você tem razão! - Disse o alemão com um sorriso - Você não chega a ter sete nomes como Jetró, o sogro de Moisés. Você tem apenas um nome duplo Itzkhok Avrom, um nome muito bonito, como os patriarcas. Assim o chamarei: Isak Avraham. Ou você quer só Avraham?

\footnotetext{
${ }^{39}$ Golem - figura lendária feita de barro, que se movimenta pelo poder divino. Pode significar também idiota ou autômato.
} 
- Contanto que o senhor não me mate, não me bata. Eu já não tenho um osso inteiro!

Os olhos do alemão marejaram de lágrimas.

Segurando-me pelo ombro, encarou-me dizendo:

- Coitado! Coitado! Você parece ter sofrido muito; apesar de tão jovem, já não tem um osso inteiro! Sim, sim! Ele é realmente ingênuo, um pouco tonto, mas um bom rapaz! - Disse o alemão para o meu judeu, que calado alisava o bigode.

- Não! Confirmou o alemão - Não tocarei em você, dou-lhe minha palavra! Você é um ser humano como eu, e além de tudo, solitário. Fique tranquilo, jamais baterei em você! E então, fica comigo?

- Ficarei com o senhor! Respondi aliviado, e fiquei com ele. 


\section{$\mathbf{X I}$}

O alemão, coitado, era muito pobre, porém, a pobreza não se manifestava na casa através da imundície, desmazelo, indolência e demais indícios de pobreza, frequentes entre todos, especialmente entre os judeus pobres, sem posses. Sua casa era limpa, tudo em seu lugar, cada cantinho brilhava e resplandecia. A madame, sua mulher, cuidava de cada fresta, não parava um instante desocupada. Cozinhava, assava, untava, limpava, costurava, remendava roupa; todos os afazeres que irritavam como um demônio as mulheres, ela desempenhava com calma e quieta, com um semblante alegre. Tinha tempo para tudo. Por mais ocupada que estivesse, encontrava tempo para ler um livro e inteirar-se sobre o que ocorria no mundo. Tinha o marido em alto conceito e ali ele reinava. Respeitava-o muito, bem como a sua escrita, impedia que qualquer angústia chegasse até ele, atrapalhando seu trabalho; na verdade, constituía com ele um só corpo, uma só alma. Sua filha mais velha, fina e delicada, costumava ajudar a mãe lavando, passando, o que fosse preciso. Costumava tricotar muito bem. Possuía apenas um vestido, que conservava sempre limpo e passado como novo, recém costurado. Todo dia estudava sistematicamente com suas duas irmãs menores, orientando-as e dando boa educação. Mantinha-as limpas com roupas brancas. O filho mais velho cursava a universidade, de onde lhes escrevia com frequência cartas calorosas, tranquilizando-os e pedindo-lhes que não se preocupassem, que não se mortificassem por não ter condições de ajudá-lo financeiramente em suas necessidades. Estava um pouco apertado, passava privações, mas tinha fé que se arrumaria de algum jeito e não morreria de fome. Consolava os pais escrevendo que recebera deles muito mais que filhos de pais abastados, muito mais do que dinheiro; eles o haviam educado desenvolvendo seu raciocínio e entendimento; refinaram seu coração com bons sentimentos como solidariedade e compaixão pelos pobres e humildes. Ensinaram-lhe a contentar-se com pouco e enfrentar problemas e situações adversas com boa vontade. Nenhum dinheiro no mundo garantiria esta formação. A leitura das cartas era feita em voz alta trazendo alegrias e lágrimas. Enfim, era uma família querida e excepcional. Eu não tinha àquela época discernimento para entender a situação como a estou descrevendo 
agora, apenas sentia que o senhor *Gutman e sua esposa eram pessoas diferentes de Leizer, o alfaiate, e de Leizerina, de Reb Azriel, o professor, e sua mulher, e mesmo do rico dono da loja de armarinhos e sua gorda e saudável companheira, a armarinheira, cuja má

*Homem bom em ídiche língua não poupava ninguém, apesar de seu colar de pérolas verdadeiras e de seu vestido de seda pura constantemente imundo e emporcalhado. Eu via apenas uma família diferente, acomodada numa casa organizada, cujos filhos não eram sujos, nem desleixados, como era usual. Porém, para apreciar a dignidade e a honra da família eu não tinha condições na época. Era demais para minha capacidade.

O meu alemão permanecia em seu quarto dia e noite. Livros estavam espalhados sobre a mesa e embaixo dela, escrevia sem parar. Ele concentrava-se em escrever com "corpo e alma". Percebia-se claramente que extraía da escrita sua força vital. Confabulava consigo mesmo, chegando até a rir, ou ranger os dentes, como se houvesse alguém a seu lado. Ao ser interrompido voltava a si e respondia com ** palavras insensatas, como se tivessem caído do céu coisas sem pé nem cabeça. Algumas vezes afastei-me de seu quarto com um dar de ombros por

${ }^{* *}$ Nisht gueshtoign, nisht guefloign - literalmente: não avançar e não voar, significando inverdades, coisas sem fundamento, insensatas não entender o que queria dizer. Eu não precisava engraxar-Ihe os sapatos porque não saía de casa, por isso mesmo seu robe e chinelos estavam muito gastos.

Minha obrigação principal não era ${ }^{* *}$ tarefa fácil. Mandava-me com frequência ao correio para enviar ou receber cartas e pacotes. Às vezes mandava-me com recados ou livros. Parecia tarefa fácil! Mas não era. Não há trabalho mais feio, amargo e difícil. A pessoa, ao receber o recado, torcia o nariz como sentisse um cheiro desagradável de

${ }^{* * *}$ Folgn a gang literalmente obedecer um curso, uma cadência, significando tarefa difícil. raiz forte recém ralada, mandando-me com a cara zangada, retornar no dia seguinte. E então, depois de amanhã. Depois de amanhã não o encontrava em casa, e ao vir novamente, ele costumava dizer: O que deseja este rapaz de mim? Não consigo livrar-me dele. Outros proibiram os empregados de receberme na soleira. Um terceiro costumava ler o bilhete, hesitava e se afastava sem dizer sequer uma palavra. Um quarto mandava um recado: Diga a seu patrão 
que não estou em casa! Entendeu?... Afinal, começaram a enxotar-me evitando-me como a uma epidemia. Ao ver-me ao longe com um recado ou um livro, trancavam as portas simplesmente ou atiçavam sobre mim um cão - um empregado... Muitas pessoas, às quais me dirigia, tinham um ataque fulminante, iam para o diabo que os carregue por um livro, seus ossos os matavam. Por que tinham tanto medo? - Eu não conseguia entender. Se algum, entre dez, se atrevia a comprar um livro, logo o arremessava ao inferno, em algum lugar debaixo da cama ou do banco, pagando-me com uma cédula rasgada. Foi um tempo terrível para mim. Desejo a todos meus inimigos que entreguem livros para judeus com posses, ouçam suas maldições e vejam as indignas alterações de sua aparência, sua fúria malévola e seu semblante carregado!

Meu judeuzinho, ou Herr Jacobsohn, vinha com frequência à casa do alemão, tarde da noite, para conversar. Quando não me sentia muito cansado, eu ficava atrás da porta para ouvir, visando simplesmente passar o tempo. Numa ocasião, ouvi Herr Jacobsohn comentar sobre um tal médico *Stein'hertz, ficando muito indignado.

*Significado do nome corações de pedra.

- Não entendo sua perplexidade?! - Disse Herr Gutman. O doutor Stein'hertz é um pequeno homenzinho e por isso é tão rico. Ele é a menina dos olhos de muitos. Isto não é novidade. Entende-se que quando alguém se torna um pequeno homenzinho torna-se também essencial e se alcança tudo no mundo.

Meu coração disparou ao ouvir estas palavras. Significa que o senhor Gutman, o meu patrão Herr Gutman, concorda que um pequeno homenzinho é a alma e é muito rico!... De tanta admiração dei um pulo, assombrado, pondo a mão na cabeça e fiquei transtornado. Naquele exato momento ele me chamou e não conteve seu riso ao ver meu rosto aparvalhado. Meu judeuzinho anuiu com a cabeça: - Ele continua o mesmo tonto de sempre, o mesmo palerma!...

Pouco tempo depois ouvi atrás da porta como o judeuzinho falava sobre um tal de **Isser Varguer, admirando sua riqueza e

${ }^{* *}$ Varguer em ídiche significa estrangulador ou sufocador. sorte. Ele era o "manda chuva" da cidade. Sua importância e poder eram excepcionais. 
- É bem simples - disse Herr Gutman. Isser Varguer é um pequeno homenzinho. É a menina dos olhos de um grande milionário. Isto tudo é natural. Não há motivo para admiração.

- Sim, é bem verdade. Este nosso mundo é bom para pequenos homenzinhos. Falou Jacobsohn, suspirando, e despediu-se. 
Bem vindo, pequeno homenzinho! Novamente as mesmas idéias anteriores. O pequeno homenzinho era para mim uma grata visita, retornando exatamente em tempo propício, quando eu estava triste, deprimido, abatido com as desgraças pelas quais passava e ávido por um pouco de repouso. A noite toda fiquei transtornado com tudo que ouvira, debatendo-me, sem poder dormir. Pensava comigo: Então Isser Varguer é um pequeno homenzinho, uma alma, é uma pessoa rica e feliz. Parece que se se é um pequeno homenzinho, é-se rico e feliz! Ao que parece, também as pessoas podem optar em tornar-se pequenos homenzinhos. E quando se tornam pequenos homenzinhos, tornam-se também ricos e felizes, alcançando tudo no mundo. Eu tenho também o mesmo direito deles por sempre ter ansiado tornar-me um pequeno homenzinho. Sim, tudo é correto e de fato muito

*Vi kumt di Katz ibern vasser? Como se dá a travessia do gato sobre a água? Denota uma impossibilidade. Foi usada então, em português a expressão: o pulo do gato, com o mesmo significado. bom! Porém resta a pergunta: como se consegue? ${ }^{*}$ Como se dá o pulo do gato? Mesmo que eu me incline, faça caretas, me encolha dez vezes, não me tornarei um pequeno homenzinho. Parece que ser um pequeno homenzinho é uma grande arte, de fato uma arte, na verdadeira acepção da palavra, maior ainda que a dos comediantes de circo. Deve haver aí um grande segredo, porque caso contrário, todos poderiam chegar a ser pequenos homenzinhos, pequenas almas, pessoas ricas e felizes...

Estes pensamentos todos não me deixavam em paz, em minha cama eu continuava pensando até que adormeci e sonhei com coisas maravilhosas.

Sonhei que encontrava na rua um pequeno homenzinho que pregava travessuras; vira-se e joga-se para todos os lados. Eis que entra pulando numa reunião da comunidade e começa a fazer com as pessoas, coitadas, a comédia. Os membros reunidos não se fazem de rogados, põem a mão na carteira e pagam bem pela representação... Daí, o pequeno homenzinho, como uma encarnação, entrou no bolso interno do paletó de um dos coletores de impostos fazendo-Ihe gostosas cócegas, que provocaram em ambos gargalhadas denotando um prazer estranho. Saiu novamente do bolso, 
já então todo dourado. O coletor de impostos cuspiu três vezes, coitado, e logo se arranjou novos bolsos!... Do bolso do coletor ele entrou majestosamente na boca de duas belas almas, quando se sentaram para fazer uma negociata sobre o preço da carne. Assim que estavam prontos para dizer: quarenta e cinco groshn por oke (45 centavos por 03 libras), passou alguma coisa recolhendo suas línguas com sua mãozinha e as belas almas, coitadas,

* Kokhlefl Concha; tem o sentido de pessoa que se imiscui nos assuntos aIheios.

gaguejaram e disseram: sessenta!... Sua boca transformou-se, que isto não aconteça para nenhum judeu, em uma bocarra, da qual, como um demônio, ele se encostou num pequeno ricaço, girando-o, girando-o. Varreu mundos até transformá-lo num arreio de couro... Do arreio de couro foi transformado em uma *concha de cozinha... e então num xale de orações interno e depois num paletó curto. De repente, encontrava-se galopando sobre a cabeça do bode comunitário que pastava, como sempre, entre o gado do local!... Enfim, o pequeno homenzinho não parava de aprontar e em tudo o que fazia era bem sucedido, muito bem, muito bem sucedido!

Invejei-o tanto que comecei a me encolher, dobrando as pernas sob o corpo, a me curvar, a me espremer e a prender a respiração, até parar de pensar, sentir, ver e ouvir - até que, de repente, e de maneira agradável me tornei um pequeno homenzinho, do tamanho de uma pulga!

Estava me deleitando. Os ossos se derretiam; todas minhas duzentas e quarenta e oito ${ }^{40}$ partes do corpo ficaram relaxadas e iluminadas. Transformei-me logo em uma alma, para todas as pessoas transformei-me na própria vida. A sorte começou a fluir de todas as direções. Eu estava viajando numa carruagem, vestido de príncipe, recebendo honrarias e presentes, os melhores e mais bonitos, de todos. Meu **bilhete da sorte funcionava. Eu conduzia toda a cidade pelo nariz, fazendo o que queria. Era apontado por todos: Vejam, vejam! Lá vai a alma, lá está falando a alma. Observem a alma! Quieto! O que diz a alma? O que, vocês têm algum dote em dinheiro, entreguem-no à guarda da alma! Vocês têm um

${ }^{* *} A$ palavra original kvitl significa bilhete, recibo, cartão. Significa também no contexto religioso um bilhete expedido por um rabino khassídico contendo bênçãos de bons augúrios para os destinatários, justificando assim o uso de bilhete da sorte.

\footnotetext{
${ }^{40} 248$ - de acordo com a tradição talmúdica o corpo é constituído por 248 partes.
} 
julgamento, uma arbitragem? Dirijam-se, eu juro, à alma! Precisam de um favor, de uma sugestão, de um presidente, de um inteligente, de um executor, de um coletor? Então somente, a alma!...

De repente, porém, comecei a esticar-me, endireitar-me, ficou-me claro nos olhos - Bom dia, bastardinho, Itzik - Avreml! Eu mesmo estou deitado em minha cama, me espreguiçando, tão à vontade, como se estivesse no *vinhedo de meu pai. Começo a apalpar-me: um toque aqui, um toque ali, sim sou eu, juro, o shlimazl em pessoa, por inteiro. De onde

*Expressão usada para lugar agradável e prazeroso. Usada com frequência pelos falantes de ídiche. vim parar aqui de repente? Fiquei com muita raiva por ter acordado e me encontrar completamente só!

Depois reconsiderei. Nada mal, vou descobrir como me tornar um pequeno homenzinho. Ainda que corra risco de morte, hei de descobrir. Logo comecei novamente a raciocinar: durante o sonho, quando me tornei um pequeno homenzinho - rico, feliz, uma pessoa fina e importante na cidade - na ocasião, parece-me, parei de pensar e de sentir, de ver e de ouvir. A conclusão lógica, então, é que não se pode ser um pequeno homenzinho enquanto não se parar de pensar e de sentir, isto quer dizer, simples é simples, não se deve pensar nem sentir, mesmo que o outro seja o bode expiatório e se suicide. O que fazer para chegar a isto? Como parar de pensar e de sentir? Esta é toda a arte! É onde **o tesouro se encontra enterrado.

Ocorreu-me perguntar a meu patrão; concluí, então, que se ele soubesse tornar-se-ia ele próprio um

${ }^{* *}$ Drinen ligt dokh take der hunt bagrobn - onde se encontra 0 cachorro enterrado; equivale a uma localização de grande dificuldade, justificando a escolha do termo tesouro. pequeno homenzinho! Seria rico sem precisar trabalhar tanto, sem sofrer. Não precisaria despachar livros indesejados e nem seria vítima da opinião dos outros. Analisei o problema sob vários ângulos e permaneci confuso.

Passei depois o dia todo perturbado; minha cabeça parecia rachar. Não sabia o que estava fazendo nem em que mundo eu vivia. Tudo o que fazia dava errado; naquele dia quebrei dois copos de chá, alguns pratos de porcelana caíram de minhas mãos, derramei um tinteiro; inverti as peças do samovar: coloquei água no lugar do carvão e carvão no lugar da água. Todos em casa, perceberam, olhando-me admirados; cochichavam entre si sentindo, pelo visto, que havia comigo algo errado. Gutman, apontando para mim, disse 
à sua mulher, colocando um dedo na testa, que tonto e atrapalhado eu sempre fora, mas hoje alguma coisa não estava em paz na cabeça do menino. Ele coitado, está muito alterado. É apenas uma criança!...

Eu permaneci durante bom tempo irritado como dez demônios, estava contrariado fazendo caretas. Não estava satisfeito comigo, nem com ninguém no mundo. $O$ coração batia terrivelmente forte, tudo estava acelerado, girando como um moinho e uma voz ficava gritando: Itzkhok Avrom! O que vai ser de você? Até quando ficará perseguido e na miséria? Torne-se um pequeno homenzinho, Itzkhok Avrom. Faça tudo o que puder e torne-se um pequeno homenzinho, vivendo feliz, com riqueza e honraria. Poderá então, aprumar-se!... A voz não parava um instante de atormentar minha cabeça. Eu andava como um sonâmbulo. Estava muito transtornado, sem saber o que fazer! Por onde começar! De repente, uma idéia luminosa - empregar-me como um serviçalzinho, na casa do doutor Stein'hertz! Lá poderei observar todos os detalhes, e com o tempo descobrir o segredo de como me tornar um pequeno homenzinho!

Era preciso ser um tonto, um menino oprimido como eu, para entender meu coração e os estranhos sentimentos que a idéia me provocara. Todo mundo, mesmo pessoas experientes e inteligentes, como pude perceber com o tempo, têm suas obsessões e manias, suas loucuras e tolices que se encontram imersas em seu coração, suas superstições e cismas, que aos outros podem parecer estranhamente selvagens, insossas e inodoras. Ninguém consegue entrar na situação do outro, sentir seu coração e suportar suas tolices. Cada um se baseia em si próprio. Um ri do outro e todos estão loucos!...

Encontrei um intermediário e prometi-lhe uma boa comissão. Ele logo me arranjou um lugar de empregadinho na casa do doutor Stein'herz. Não demorou muito e deixei meu bom senhor Gutman, quase fugido, sem uma despedida sequer, e transferi-me para meu novo lugar, para o médico! 


\section{XIII}

Assim que transpus o umbral da casa do doutor pela primeira vez, comparei-me somente a um percevejo que se infiltra numa fresta de nossa cama e aguarda o dia todo, forçando a vista, para ver quando nós, pessoas, nos livraremos de nossos afazeres e nos deitaremos na cama. Assim, ele travará conhecimento com quem lhe dará o sustento... Essa é a única finalidade de sua vinda, ter de nós, belas criaturas, de onde sugar. O doutor Stein'herz, o fino cavalheiro, estava ocupado com assuntos importantes, amontoava ouro de todos os lados; nem tinha consciência de que hoje, pela manhã, se instalara em sua casa um tipo de percevejo - bastardinho Itzik Avreml, que irá observar todos seus movimentos, captar a essência de seu sustento e aprender a arte de transformar-se em um pequeno homenzinho.

O dia inteiro eu trabalhava fazendo as tarefas que a madame determinava e ansiava, em silêncio, poder finalmente conhecer o pequeno doutorzinho! À tardinha abre-se de repente a porta e entra um homem alto, corpulento e barrigudo, grande como um *gigante. Ao vê-lo arregalei um par de olhos como era meu estilo, parecendo um tonto. Meu olhar não agradou ao grandalhão.

${ }^{*}$ Gog - Magog no original, lembrando o texto bíblico.

Perpassou-me com seus olhos e irritado berrou em ** grego:

- O que você está encarando, seu asno! - Falou ele em russo.

Tal linguagem eu nunca ouvira. Fiquei confuso, comecei a tremer e me agitar e antes que me desse conta, gaguejei:

- Eu me chamo Itzik Avreml, meu nome Avremke... Sou órfão... Sou um empregadinho aqui!...

- Você é um grande tolo! - Disse o ${ }^{* *}$ No texto ori-
ginal a citação
se encontra em
russo, porém,
exatamente co-
mo em portu-
guês, a língua
desconhecida é
referida como o
grego. grandalhão. Veja, grosseirão, quando eu entrar, corra para tirar meu casaco de pele e minhas galochas! Ouviu?!

Assustei-me tanto com ele, que me lancei ao chão com todo meu tamanho e abracei com força, com minhas mãozinhas, suas pernas fortes para tirar-Ihe as galochas. Deus me ajudou a superar o susto e o grandalhão entrou 
na sala. Mais tarde levei o samovar e fiquei servindo a bela figura e a madame, a noite toda.

Mais tarde, no meu leito, fiquei tentando adivinhar quem seria o atarracado grandalhão? A noite toda ele ficou com a madame brincando. Ele a chamava de queridinha. Ela o chamava de meu gatinho. Que tipo de gatinho era? Eu me admirava, onde estaria o doutor. Durante alguns dias o grandalhão fez suas demoradas visitas. Assim que chegava ou saia eu me estendia no chão para tirar-Ihe ou colocar-Ihe as galochas. Ele ficava com as mãos na cintura e olhando o teto com empáfia. Ele não se importava nada que seus pés gordos, como cascos, esmagassem meus dedos. Eu ainda não sabia quem era o grandalhão, este saudável Esaú ${ }^{41} \ldots$

Após terminar o serviço à noite, uma ocasião deixei o gatinho na sala brincando com a queridinha e fui à cozinha conhecer melhor a cozinheira. Com uma cara de coitado, perguntei-Ihe: - Diga-me, Dvossie, peço-lhe: quem é o grandalhão que vem com frequência? Ele é muito familiar da madame e fica para dormir em sua alcova?

- O quê? Respondeu a cozinheira, olhando-me admirada - Quer dizer que alguém dorme na alcova? O que quer dizer alguém?

- Como eu sou judeu!

Comecei a jurar - Que eu seja assim consolado! Que ouça o toque de chegada do Messias, como eu mesmo vi, com meus próprios olhos, e ouvidos, vi e ouvi ele lá entrar! Juro! Como se chama mesmo o gatinho ou a gatinha? Com os diabos! E eu sei lá? Com certeza, que eu permaneça com a senhora tão saudável e feliz! - Continuei jurando.

- Então, e o patrão? - Disse a cozinheira alegre, com olhinhos tão travessos e brilhantes como ao assar o pão de sábado.

- O patrão! Retruquei embasbacado - como alguém que sufoca e não quer mostrar - O patrão não dorme em casa, me parece. Ele precisou viajar a trabalho, para resolver um problema...

- Então, se é assim a história - disse a cozinheira com uma alegria selvagem - Estou disposta a ir verificar por mim mesma. Arrumarei um

\footnotetext{
${ }^{41}$ Esaú - lembra o brutamontes da bíblia, significando também gentio.
} 
pretexto. Vale a pena ver que as madames não são melhores que as empregadas... Que não desperdicem o seu charme!

Em alguns minutos ela retornou esbaforida, vermelha como fogo, abriu para mim uma bocarra amaldiçoando-me até a última geração:

- Ah, seu demônio! Seu moleque! Você merece ser partido como um arenque. Que te partam mesmo! Que ousadia de um fedelho, de uma alma fedorenta, de um tal pedaço de carne, um rapazinho cheio de vermes! Abrahão sem vergonha! Maldita seja tua cabeça, teu corpo e tua vida. Que você não levante na ressurreição dos mortos. Tão jovem e já capaz de arquitetar tamanha *confusão. Que você nunca encontre um bom lugar para repousar. O próprio patrão está com a madame lá na alcova!

- Deus esteja com a senhora Dvossie! O que a senhora está dizendo? - Eu queria consertar minha sorte junto à cozinheira - Verifique o que a senhora está dizendo.

${ }^{*} A$ confusão é oriunda da sequência de palavras absolutamente sem sentido, quais sejam: loksh, boidem, póletse - significando: macarrão, sótão, prateleira. Significa que este grandalhão, este gordo atarracado?!...

- Que o diabo o carregue até sua última geração, seu moleque! Gritou a cozinheira pegando o atiçador - Quer dizer que você chama o dono da casa de grandalhão, moleque atrevido! Saia, seu mal educado ou eu racho sua cabeça!

Arranquei-me rápido da cozinha e subi sem fazer barulho. Quando me deitei não consegui dormir. Eu estava atônito com toda situação! O que vejo e o que ouço? Então, o doutor é alto, grande e gordo?! Por que o senhor Gutman teria dito que ele é um pequeno homenzinho?! Teria ele mentido? Não, não pode ser! Gutman jamais enganou alguém. Só dizia a verdade. O que estaria acontecendo? Talvez houvesse algum truque, uma comédia?! Se pessoas podem se transformar em lobo, em lobisomem, e assumir diversas formas - e isto é verdade, claro como a luz do dia, pois ouvi da boca de velhos judeus de barba branca, então é fácil de acreditar que pessoas podem se transformar em pequenos homenzinhos e obter sua felicidade! Mais uma vez, há, há! Se uma pessoa pode se transformar em lobo, um animal selvagem, que corre loucamente e uiva, que devora e agride quem encontra, não deve ser difícil a transformação de um homem num pequeno 
homenzinho. A forma continua a mesma, com a mesma cara como todos, só que de grande fica-se pequeno. Parece que estou no caminho certo, graças a Deus. A história parece que é mesmo assim. Aqui está um artifício, uma mágica! É preciso examinar bem, pesquisar e comprovar e descobrir o segredo. Nem que o mundo se acabe!

Com esta nova idéia, meu raciocínio infantil, como vocês vêem, avançou e se fortaleceu. Minha concepção prévia de que os pequenos homenzinhos chegam ao mundo prontos era muito ingênua. Eu acreditava que pequenos homenzinhos vêm ao mundo prontos. Agora já era mais elaborada, dependia de força e intenção. Era uma coisa espiritual através da natureza. Isto significa que os homens chegam ao mundo todos assim como são; mas parte pode-se transformar em pequenos homenzinhos através de poderes especiais e demônios. Aí, já há o sobrenatural!...

Alguns dias depois, quando estava atrás da porta do consultório do médico, consegui ouvir o seguinte diálogo com seu boticário prático.

- Esta semana, benza Deus, está sendo muito boa para o senhor, doutor! Eu muito contribuí para este resultado. Cumpro minha parte com perfeição. Aonde vou, apregôo sua capacidade, que o senhor é o médico adequado, só o senhor. No entanto, o senhor permanece indiferente com relação a mim.

- O que você está dizendo, Guetzl? E como foi ainda ontem?

- O que aconteceu ontem de excepcional?

- Ele tem a memória curta! O que aconteceu, você esqueceu, Guetzl? A troco do quê indiquei ao doente de ontem a aplicação de trinta sanguessugas? Cá entre nós, ele precisava dos sanguessugas como eu e você! Teria bastado um lenço úmido na cabeça. Que feio, Guetzl, pode se envergonhar! Na verdade eu o fiz só por sua causa; fui, ontem, um pequeno homenzinho!....

- O senhor foi ontem um pequeno homenzinho! Como o senhor diz. Eu tenho sido, por sua causa, sempre um pequeno homenzinho, tanto anteontem, como ontem, como hoje. Cá entre nós, doutor, o paciente de hoje precisava de um médico? Ele tem um simples catarro. Por minha indicação ele o chamou e provavelmente o chamará durante as próximas semanas duas 
vezes ao dia. Tudo bem! Ele é podre de rico, um porco. Que fique doente algumas semanas...

- E então, Guetzl? O que você deseja?

- Sanguessugas, doutor! Tenho muitos sanguessugas!...

- Fique tranquilo, Guetzl, você Ihe aplicará sanguessugas. Pelo menos você tem boa mercadoria, Guetzl? Você sabe como sou meticuloso nestas coisas...

- Fresquíssimos sanguessugas, doutor, que Deus me ajude! Eu mesmo detesto enganar os outros...

* No original, em meu coração, o que seria estranho para o leitor brasileiro.

Ah, Ah! Assim é que é?! Comecei a pensar com meus *botões após ouvir toda a história e pude entender melhor. Deitado na cama cheguei à conclusão que ser um pequeno homenzinho não é simplesmente ser pequenino, como eu, bobinho, pensava antigamente. Pode-se ser grande, bem grande, e no entanto ser um pequeno homenzinho; permanecer sempre

**No original foi usada a mesma expressão já comentada: onde 0 cachorro está enterrado.

${ }^{* * *}$ Raibn zikh in der velt tzvishn lait friccionar-se no mundo entre pessoas honradas, significando sairse bem, ser bem sucedido. boticário prático para aplicar sanguessugas. Preciso procurar outro jeito, outra forma de sugar, porém, não simplesmente sangue. Deve haver outras alternativas. Aqui não tenho mais o que fazer! Então o que é que se faz agora? Ah! De repente dá-me um estalo na cabeça! Talvez, Isser Varguer!? Juro, não é má idéia. Preciso ter acesso a ele. Como eu sou judeu, o coração me confirma Isser Varguer! Ele é um pequeno homenzinho, e muito bem sucedido! Ah?!...

Fiquei com a idéia fixa e não consegui dormir quase a noite toda. Naquela noite amadureci alguns anos e senti a diferença. Na manhã seguinte, sem mais delongas, procurei meu intermediário, que por uma comissão mais alta que a anterior, conseguiu em alguns dias empregar-me junto a Isser Varguer. 


\section{XIV}

- Só uma palavra, rabino!... O que devo fazer?...

Ouve-se, durante a leitura, uma voz grave atrás da porta. Sem aguardar resposta, invade o aposento um judeu ruidoso e corpulento, vestindo uma camiseta remendada, onde através dos buracos, vêem-se pedaços sujos do xale ritual interno, cujas franjas balançam-se até o joelho. Grossas cuecas, com o perdão da palavra, apareciam. Usava botas grosseiras, cheias de lama, talvez do inverno passado ainda, que exalavam um cheiro forte de suor misturado com iodo.

- Ah, Beni! - Diz o rebe encarando a figura O que você tem a dizer, Beni?

- O que eu deveria dizer? - Responde *Beni,

* A linguagem de Beni e sua mãe é entrecortada, popular e contém erros gramaticais. Não foi possível transmiti-la na tradução. coçando indeciso a nuca. - Ah, nada, digo eu. Dinheiro para o mês já recebi com a rebetzn. Água, já lhe entreguei ontem à noite, seis vezes. Tive que trazer água ontem, a noite toda. Reb Itzik Avrom morre e eu carrego água. Entreguei bem aos belos proprietários, seus vizinhos que derramaram toda a água. Hoje não tem água nem para cozinhar. De quem é a culpa? Do entregador! O outro morre, e eu tenho a culpa... Fico carregando água! Para o diabo! Não dormi a noite toda, só de madrugada. Quando eu fechei um olho mamãe vem me acordar, que ela tenha longa vida; me acorda: - Beni, Beni! Acorde e passe 0 ferrolho na porta. Estou indo na sinagoga para a primeira reza e aproveitar a oração da Santificação. Da sinagoga irei direto ao cemitério pois tenho aniversário de morte. Sobre o fogão encontra-se uma panela de mingau, tome conta dela, Beni!. Vi-me livre de mamãe e me deitei. Cochilei e ouvi um pic, pic, pic. O galo e as galinhas, que vão para o inferno, estão ciscando um bico de pão. Saborosamente continuam ciscando sobre a mesa. Grito para elas: Xô, para você hoje, xô, para você amanhã. O que sabem as galinhas? Continuam picando. Justo sobre o chão encontrava-se uma colher de pau, maldita seja ela, usada para a carne. Agarro-a e persigo as galinhas. Ouço então as

**Entre os há-
bitos alimen-
tares judaicos
existe a proi-
bição de mis-
turar leite e
carne, oriunda
das citações
bíblicas: Deu-
teronômio
14:21 / Êxxodo
23:19.
galinhas sobre o lado do fogão. Em vez de meter a colher nas galinhas, meto-a na panela de leite. ${ }^{* *} A$ colher de carne na panela de leite, criando um 
"quiproquó. A colher de carne, rebe. E então? Quando nova não foi marcada com três entalhes, como deve ser uma colher de leite judaica. Então é de carne, como eu sou judeu! Nunca comi porco, que Deus o livre. A panela é de leite, está sempre do lado de leite do fogão. Desde que minha cabra morreu, adeus leite! Uma figa para o leite! Hoje, rebe, dê o veredicto.

- Era grande a panela? - Pergunta o rebe!

- Maior que minha cabeça! - Responde Beni -

* Shaile - do hebraico - questionamento problemático que se leva ao rabino para resolver, gerando equívocos e confusão

Quase do tamanho de um balde. Quando me alimento com todo seu conteúdo pela manhã, trabalho o dia inteiro, sem comer mais nada.

$$
\text { - Kosher }{ }^{42} \text { ! - Declara o rabino. }
$$

Beni sai e uma pequena mulher entra correndo com um lamento, uma queixa: - Rebe não aguento mais! O senhor teve boa intenção tentando nos reconciliar, evitar o divórcio. Porém, essa vida só posso desejar a meus inimigos. Seus preciosos conselhos adiantaram tanto para ele como um grão de ervilha para a parede. Ele não ouve o mundo. Faz o que bem entende e está me matando. Estou me esfalfando: empresto e tomo emprestado. Compro ovos e galinhas para poder ganhar alguma coisa e assim sustentar a alma das crianças famintas, esfarrapadas e largadas. E ele... só sabe da casa de orações khassídicas ${ }^{43}$, onde passa seus dias bebendo, conversando e discutindo, ao pé da lareira. Quando chega em casa quer ser servido. Não olha e nem pergunta pelas crianças, não se importa com elas, como se fossem estranhas. Nunca me dirige uma boa palavra, trata-me como sua propriedade, sua empregada, que não merece lavar-lhe os pés e beber a água. As únicas palavras que ouço dele são: Bobona! Bruxa! Ordinária! Por ocasião de algum feriado, viaja para seu rebe tomando de mim meu último centavo e fica lá durante um bom tempo com sua turma, iguais a ele. Nem começa a se importar com a casa, mulher e filhos que

*Do hebraico aguná - significando amarrada. Mulher cujo marido se encontra desaparecido, do qual ela só ficará livre se sua morte for comprovada. anseiam por um pedaço de pão e estão se consumindo, coitados. Se eu reclamar com alguma palavra ele ameaça transformar-me em uma *agune",

\footnotetext{
${ }^{42}$ Kosher (do hebraico) - adequado.

${ }^{43}$ Khassídicas - refere-se aos devotos de um rabino que é seguido como um mentor, sem questionamentos.
} 
esposa abandonada, e mostrar-me que uma judia velha não vale nada! Uma judia velha, diz ele, é um nada de nada. Hoje pela manhã, ao voltar da reza, encontra a casa tão fria, que espanta até os lobos. Há mais de dois dias não passa fumaça pela minha chaminé. As crianças tremem de frio, ficam ofegantes e pedem comida. $O$ bebê no berço está rouco de tanto berrar, quer mamar, coitado, e eu não tenho uma gota de leite. Não ponho nenhuma colher de comida na boca há dois dias.

- Bobona! Dirige-se ele a mim, bem humorado - Prepare-me uma camisa e meu capote sabático numa sacola. Entendi que ele pretendia viajar para lá com seu bando. Aproxima-se a festa de khanuke. Eu estava com o coração amargurado e reagi: Seu bandido! Quem você pensa que é? Olhe pelo menos seus filhos, como eles sofrem e se acabam! A você só interessam coisas fúteis! A mulher, tudo bem, você diz, não é ninguém, uma bobona, uma judia velha, uma cadela! Porém seus filhos, pelo amor de Deus! Assim que acabei de falar ele caiu em cima de mim com raiva e aos gritos: Bobona! Você vai ficar me xingando e citando bobagens que sua mentalidade feminina não alcança! Sua ordinária! Hoje vou dar um basta definitivo, vou abandoná-la para sempre! Para que você se torne uma desolada esposa abandonada. Tudo bem, eu sou o homem e a você, ordinária preciso-lhe ensinar para que você fique sabendo o que é uma judia!... Não se acalmando com os xingamentos começou a me beliscar. Eis minhas mãos, todo meu corpo está com hematomas! Pelo amor de Deus, rebe, salve-me! Que ele me dê o divórcio! Não aguento mais...!...

- Vá, vá para casa! Diz o rebe com a voz embargada e os olhos marejados de misericórdia. Mandarei meu auxiliar ainda hoje para trazê-lo até mim.

Mal saiu a pequena mulher, entra a zeladora arrastando as pantufas, vestindo a jaqueta só sobre uma manga e com um lençol debaixo do braço.

- Deus ajude! Diz ela para o rebe com uma carinha piedosa, depois de ter passado a mão na *"mezuze" e beijado a ponta dos dedos - Eu queria importuná-lo por um instante, rebe, que o senhor tenha

${ }^{*}$ Caixinha colocada no umbral das portas das casas de judeus como um lembrete. Contém em seu interior uma tira de pergaminho com inscrições de versículos da Torá, de um lado, e do outro Shadai, um dos nomes de Deus. Presta-se para manifestações artísticas nos mais variados materiais 
longa vida, com uma pergunta de mulheres. Desculpe, rebe, eis o lençol.

Depois que o rebe resolveu o problema do lençol, aproximou-se da mesa e prosseguiu a leitura. 


\section{XV}

Isser Varguer era dos mais destacados cidadãos de Tsvuetshitz.

Todos se debatiam como se tivessem febre, quando ele proferia uma palavra. O que significa, ele não era pouca coisa, esse Isser! Ele mesmo não fazia negócios, não punha a mão em *água fria, embora sua casa fervilhasse como uma caldeira, um entrando, outro saindo. Todo o mundo, todos com Reb Isser. Poder-se-ia imaginá-lo um grande erudito e privilegiado. Ao contrário, nem um *Arainton di hant in kalt vasser - por a mão em água fria. Significa: trabalhar. pequeno erudito. Mal e mal sabia rezar. Era um **"nada", isto significa obtuso em hebraico. No entanto tinha uma grande bolsa, muito grossa, para carregar o xale de orações e os filactérios, feita de vários tipos de peles finas, adornadas com bordados vermelhos. Dentro dela eram encontrados o livro de

${ }^{* \star} A$ expressão usada no original está em hebraico com o significado de "nada" - ninharia.

rezas, "Derekh Khaim"- Caminho da Vida, com todas as leis necessárias, o livro dos Salmos para todas as circunstâncias, também uma pequena Lei de Israel além de "Shaarei Tzion"- Portões de Sião.

Tinha a mão pesada para escrever. A caneta, como por desaforo, de jeito nenhum queria ir a seu mando: ele a empurrava para lá e ela ia parar em Boiberik, ela espirrava, fazia borrões, raspava, contorcia-se e se punha de pé. Cada palavra, coitado, Ihe custava muito trabalho para escrever e antes de conseguir sua assinatura, Isser, preto no branco, seus olhos quase saíam das órbitas. Esvaía-se em suor. Limpava a testa com a manga da camisa ou do capote e arfava como se tivesse rachado lenha. Pode-se dizer que uma qualidade ele tinha, não era meticuloso, como outros, em soletrar. Uma letra não desempenhava, para ele, um papel importante; aparecer antes ou depois, ou mesmo não aparecer, não Ihe importava; pode-se muito bem deduzir o que está escrito. Quando ele tinha alguma dúvida com relação ao assunto, aí a pena vinha em seu auxílio. Ela se apressava em fazer uma crispação com um borrão e assim ele já podia sair-se com autoridade. De todas suas coisas apresento-Ihes a sua versão de Noé, Noiekh ${ }^{44}$ em hebraico, com todos seus sete erros ou sua tradução de hebraico da Hagode: Teirakh avi, Avrohom

\footnotetext{
${ }^{44}$ Há uma maneira de grafar a palavra em hebraico com sete erros, reforçando um exagero de desconhecimentos.
} 
veavi, Nokher veiavdó. Não sei qual vocês vão preferir. A mim agradam as duas.

Bem, eis aí o estudo de Isser. E no que se refere a sua linhagem não havia do que ter orgulho. Ele não provinha da bandeira dourada; não comeu, na juventude, brioches com manteiga. A verdade, como pude constatar mais tarde - ele era um pequeno homenzinho e foi mais bem sucedido que outros com muitos conhecimentos ou que tinham bens materiais. Isser tinha 0 judeu mais rico da cidade na palma de sua mão - só Isser, em geral Isser, sempre Isser! Isser era sua alma, seus pés, suas mãos, seu tudo. Por isso ele era importante, o mandachuva na cidade.

Com este Reb Isser aprendi muitas coisas. Ele, só ele, foi meu mestre verdadeiro. Ele me abriu os olhos, *tomou-me pela mão e fez-me entender muitas coisas que acontecem pelo mundo. Respondeu-me as questões árduas, esclareceu exageros, enigmas de nosso comportamento; ele deu-me status, polindo-me, refinando-

${ }^{*}$ Er hot mir in moil a finguer araingueleigt, cuja tradução é colocoume um dedo na boca, pressupondo confiança e carinho. A opção de tradução foi a expressão tomoume pela mão. me até transformar-me num receptáculo. Em resumo, ele me mostrou um caminho e revelou o segredo de como tornar-se um pequeno homenzinho.

Aqui a leitura foi novamente interrompida. A rebetzn entrou falando sem parar, vindo postar-se diante do rabino, meio zangada, com a seguinte queixa:

- Não dá para aguentar. A casa está cheia, benza Deus, e todos perguntam onde está o rabino. E eu respondo que está ocupado agora, mas, não adianta. Todos querem o rabino. Quem não está lá? Os dois judeus do julgamento de ontem - estão; o homem da casa de banhos - está. Se a cidade não consertar a casa, ele grita, ele não esquentará mais os banhos. Isto já está fora dos honorários do rabino. Os açougueiros com um novo ** problema - também estão; o enviado do Rabino Meir Baal Hanes - está; o da yeshive, o dos queimados e a esposa abandonada, com os três filhos, estão todos aqui. Não adianta explicação. O próprio rabino precisa ir até eles. Eu nem quero mais aparecer.

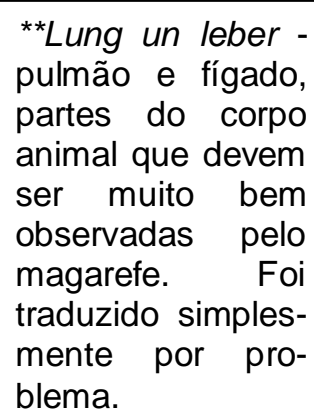
pulmão e fígado, partes do corpo animal que devem ser muito bem observadas pelo magarefe. Foi traduzido simplesmente por problema. 
O rabino levanta-se pedindo desculpas aos presentes e solicita que esperassem por ele.

- Oh, reb Mêndele! Como está? - A rebetzn dirige-se a mim após a saída do rabino. - Já faz tempo que o senhor não tem vindo. O senhor, Reb Mêndele, trouxe para nós, mulheres, livros novos?

- Livros religiosos para mulheres! - Sorri um dos ricaços com uma cara azeda.

- Os homens pensam que só para eles devem ser editados livros - diz a rebetzn ofendida: Tudo para eles. As mulheres não têm alma, não são gente e não precisam, neste mundo, de coisa alguma. Para elas é suficiente o que vivem, o que carregam, que geram filhos e os criam, cozinham as refeições, cuidam de seus maridos e têm, elas próprias, uma vida miserável.

- Bendito o Senhor que nos encontramos com saúde - respondo eu. - Tudo bem! Não me esqueci da senhora, rebetzn. Trouxe-lhe um livro de súplicas - uma tekhine - da terra de Israel - recém saída. A senhora vê, rebetzn querida, está culpando os homens sem razão. As senhoras são levadas em consideração. Venha, por favor, e examine o livro feito especialmente para as senhoras. Parece que já lhe causamos muitos transtornos... Porém não é a isto que me refiro...

- Ai, ai, rebetzn, a senhora quer fazer uma revolta entre as mulheres! Diz um ricaço com um sorriso doce - Ouvindo-a, nossas mulheres empinarão os narizes, começarão com novas exigências e vão querer, Deus o livre, o divórcio! E já que chegamos ao assunto, eu lhe pergunto, rebetzn, que Deus the preserve a saúde, por que teria o rei Salomão escrito que mesmo entre mil mulheres ele não encontrou nenhuma certa.

- Exatamente por isso, não encontrou - alegou a rebetzn - pois tinha mil mulheres, desculpem. Os homens que procuram ter muitas mulheres não podem mesmo ter uma certa. Digam-me senhores, se estivessem em seu lugar seriam melhores?...

- Por que, então - manifestou-se outro senhor - está em nossos livros que toda a sabedoria de uma mulher consiste apenas no uso do tear?

Responde a rebetzn: 
- É porque os homens os escreveram. Claro que vocês são os sábios. Vocês dominam e têm as mulheres, coitadas, em suas mãos! O mais forte é sempre o mais inteligente, o que tem razão.

Como diz o ditado: ${ }^{*} \mathrm{O}$ anjo da morte abate e permanece com a razão. Deixando os ditados de lado, eu thes pergunto, nada mais do que, como podem os senhores dar uma decisão, que sabemos e vemos com nossos próprios olhos não ser justa? Por acaso, não tivemos mulheres profetizas e sábias na história dos judeus?! Por acaso, não ${ }^{*}$ ditado em
ídiche tem um
certo encanto por
ser rimado: Der
malakh hamoves
shekht un blaibt
guerekht. existem mulheres sábias e eficientes, nos dias de hoje, que chegam a suplantar os homens? Me parece que mesmo aqui, em nossa cidade, podem ser enumeradas muitas mulheres que, por sua eficiência e sabedoria, os homens Ihes são gratos, devendo-lhes sua honra e sua riqueza. Não seriam ninguém sem suas esposas. No entanto, jamais acontece de em eventos comunitários ou assuntos importantes serem citados estes cidadãos que não servem nem para amarrar o rabo de um gato, com o perdão da palavra. Mulheres são consideradas como nada. A decisão é sempre tomada pelos homens. Homens, nas reuniões - homens, na sinagoga - homens, até na casa de banhos. Desculpem-me: homens, vão tomar banho!...

- Rebetzn, a senhora está hoje muito exaltada - continuou falando o ricaço - A senhora parece ofendida, talvez não esteja bem e descarrega sua raiva sobre os homens, coitados!

- O que devo fazer?! - Responde a rebetzn com um suspiro profundo saído do coração - Quando falam sobre as mulheres e eu examino nossa amarga e miserável situação, meu sangue ferve.

- Veja, rebetzn! - Eu me antecipo e entrego-Ihe o livro de súplicas, - o único remédio para seu coração cheio de mágoas e ferimentos. $O$ livro de súplicas é bom para as mulheres, especialmente para a senhora, eu juro!

- É a pura verdade, Reb Mêndele! - Respondeu a rebetzn anuindo com a cabeça. - Para nós, mulheres infelizes, é o único paliativo para corações amargurados e feridos. É a única maneira de desafogar em pranto e desamor o pesado e amargo estado de ânimo, em lágrimas ardentes... É só 
uma dor, um desabafo. Os homens não entendem e nem querem entender o que nos vai no coração; como eles riem e caçoam das súplicas femininas e não nos concedem este único alívio sequer. Eles devem sentar alguma vez no espaço feminino da sinagoga durante um feriado ou um sábado e ver lá muitas mulheres infelizes, que mal conseguiram sair de casa: uma com um destino miserável de seu marido, outra esposa abandonada; uma com gravidez difícil, outra cujo bebê doente não a deixa dormir noites inteiras, coitada; uma com as mãos inchadas e queimadas do fogão, outra preocupada e pálida pela constante opressão, como são todas as mulheres tristes e oprimidas, repetindo o que a condutora da reza diz; com lamentos e queixas, os olhos voltados para o Pai fiel e misericordioso, o Criador, no céu; debulhadas em lágrimas e choram do âmago de sua alma. Se os homens as observassem com seus próprios olhos, pela minha vida, não abririam a boca para ridicularizá-las em suas súplicas femininas... Agradeço ao senhor, Reb Mêndele, que não se esqueceu de mim. Logo Ihe pagarei pelo livro. - Disse a rebetzn para mim e saiu silenciosamente.

Todas as pessoas na sala ficaram em silêncio como se tivessem perdido a fala. A rebetzn deixou-me melancólico. Permaneci triste num canto, analisando cada palavra sua. Suas palavras estavam embebidas, como uma esponja, por sentimentos amargos e agudos que furavam e picavam o coração, quanto mais as analisava. Para mim, parecia, na ocasião, que haviam feito uma autópsia, diante dos meus olhos, de uma pessoa viva, tirando-lhe 0 coração ainda quente e pulsante, abrindo-o para ver seu interior. Confesso que foi a primeira vez em minha vida que tive a oportunidade de examinar de forma séria a ignóbil situação das mulheres, compreender seu coração e ter por elas misericórdia. Assim, acho eu, deve se sentir um não judeu, um bom gentio culto quando começa a analisar a condição dos judeus enfraquecidos, avaliar sua importância e lamentar os infortúnios a que são submetidos pelos países do mundo - seus poderosos amos, patrões, mandatários...

As pessoas na sala começam a se agitar e eu interrompo minhas introspecções.

- Por que o senhor suspira tanto, Reb Khone? Indagou um ricaço emitindo ele próprio um gemido 
- Veja, Reb Berish! - Disse Reb Khone franzindo a testa - Eu mesmo não sei qual a intenção de Itzkhok Avrom em toda esta história. Aparecem palavras que não combinam com ele. Qual sua opinião, Reb Berish, sobre suas frases mordazes? O senhor conhece seus alcances. Quem sabe o quanto ainda demorará a leitura. Não tenho tempo hoje e estou *impaciente.

- Eu também não aguento mais - disse Reb Berish. O senhor, Reb Khone, diz que eu sou um conhecedor. ${ }^{* *}$ Fé... fé... fé... Confesso que por esta de Itzkhok Avrom eu não esperava. Parece que ele entendia do assunto, não era tolo. Talvez fosse uma idéia irmos todos embora, já que somos pessoas ocupadas. Sugiro que nos retiremos.

- Deus o livre! - Manifestaram-se alguns ricaços - Pareceria que nos sentimos culpados. Ao contrário, permaneçamos sentados ouvindo até o fim. O melhor é ficarmos impassíveis.

Reb Khone tornou a suspirar, e Reb Berish

*Ikh zitz oif shpilkes estou sentado sobre alfinetes. Expressão que denota impaciência.

**Fé, Fé, Fé interjeição ídiche que denota desprezo e desconsideração. envolveu com a mão o nariz e grunhiu como alguém que está com muita raiva.

- Um bom dia, bom dia! - diz Reb Faivish, entrando na sala radiante e alegre, com o rosto vermelho, como se estivesse um pouco "alto". Estive ocupado até agora sem ter podido chegar antes! - Olhou de relance os presentes perguntando: qual é a história, por que todos vocês estão tão tristes.

- Nós é que perguntamos: qual é a história, para o senhor estar tão alegre, Reb Faivish? - Retrucam os cidadãos como se não tivessem percebido que ele já tomara um trago na Santa Sociedade de Sepultamento.

- Parece que vocês já terminaram a leitura, sem mim. - Disse Reb Faivish - É uma pena, eu juro, que eu não tenha ouvido. Deve ter sido muito bonita.

- Que o senhor tenha a mesma sorte! - Rugiu baixo Reb Berish, num resmungo.

- Não se preocupe, Reb Faivish, ainda sobrou bastante para o senhor ouvir, penso eu! - Consolou-o um dos presentes com um sorriso amargo e a cara azeda e distorcida. 
- Bom dia, rabino! Disse Reb Faivish festivamente para o rabino que chegara até a mesa - Desculpe, rabino, por ter atrasado. Até agora estive ocupado com Itzkhok Avrom. Só agora os membros da Santa Sociedade acertaram as despesas do funeral. Ambas as partes estavam um pouco intransigentes. A Santa Sociedade estava com a razão e se impôs. De quem a Sociedade *tirará vantagem se não de um defunto tão bem nutrido? É pena, enquanto o rabino leu, eu não ter ouvido. Ô-ua, ô-ua! Uma tal história, pela minha vida - mais doce do que o mel! Ontem eu simplesmente me deliciei ao ouvi-la de sua santa boca. Afinal, deve ser uma preciosidade. Que pena eu ter atrasado. Ô-ua!

- Com certeza, Reb Faivish! - Falou o rabino sentando-se em sua cadeira. - Lemos uma boa parte, mas tudo bem, ainda restou bastante. Retomemos a leitura e *Oplekn a beindl - lamber um osso. que foi traduzido por levar vantagem. vamos até o fim. 


\section{XVI}

Sem delongas, o rabino retomou a leitura:

Isser era por natureza uma pessoa irascível e reservada. Nunca se conseguia saber nada do que ele estava pensando, nem do que estava pretendendo. O que ele achava ele não falava, e o que ele falava não era o que ele achava. Mesmo sua própria esposa não sabia nada a seu respeito. Mantinha-se distante dela e dos filhos. Todos, em casa, tinham por ele grande respeito - não costumava falar muito, nem argumentar, mas se chegasse a proferir uma palavra devia ser atendido, imediatamente. Sua expressão estava sempre, em todos os tempos e oportunidades, impassível: sempre sério e pensativo. Nunca se ouviu um riso franco, esporadicamente apenas, sorria e mesmo assim, era um sorriso azedo, apenas com o distender de um lado dos lábios finos. O resto do rosto não denotava nenhum *vestígio; permanecia extremamente frio e os olhos vidrados, como antes.

Isser tinha, porém, um grande amigo ao qual se ligava de corpo e alma. Com ele era tagarela, dele nada escondia. Gostava de passar tempo em sua companhia com

${ }^{*}$ Remez deremizá no original - Tratase de uma palavra hebraica reforçada por seu sinônimo em aramaico, significando vestígio e indício.

um bom papo e um copo de vinho. Em sua presença, Isser sofria uma metamorfose deixando de ser Isser. Seu coração escancarava-se para o amigo que podia nele penetrar livre, ler e conhecer todos seus segredos. Falava sem rodeios. Tirava a mão do coração e soltava a língua, especialmente quando um pouco "alto". O que ia na alma, vinha na boca. Com frequência se juntava a ele em seu aposento e assim, isolados, abriam-se em longas conversas francas, vindas do coração. Isto para mim não era novidade. Há muito eu adquirira o hábito de ouvir atrás da porta o que se falava.

Quero, aqui, transmitir-lhes um resumo das conversas de Isser com seu bom amigo, o que lhes dará a noção apenas parca, da conduta de Isser, seu estilo de vida e sua ótica em relação ao mundo, no qual me mantive firmemente.

- Ouça, meu bom amigo! - Disse Isser Varguer uma vez quando acabaram de chegar alegres e um pouco embriagados, ao entrarem no aposento separado - Ouça, meu tolo! Digo-Ihe que um povo tão querido e bom 
como os judeus, não existe no mundo todo. De fato um bom povo, um povo de ouro. Na verdade pode-se ter deles - um centavo...

- Diga melhor, Isser, um povo tolo; não existem tolos como os judeus no mundo inteiro.

- Com razão, meu bom irmão! Seja dita a verdade. Mas tão querido, tão bom, tão útil, tão precioso, tão ingênuo como nosso povo escolhido, não existe, não existe!

- Por que está se alongando em elogios ao povo de Israel, Isser? Chega de papo! Conte-me, melhor, o desfecho da reunião de hoje?!

- Qual reunião? O que você está tagarelando tanto, meu bom amigo?

$$
\text { - Fale *coisa com coisa, Isser! O que }
$$
significa esquecer a reunião de hoje sobre a carne?

- Nem sei do que você está falando, tolinho! Coisa importante, a reunião! Teve tanta utilidade,

${ }^{*}$ Redn Diburim - que significa: falar (em ídiche) dizeres (em hebraico). Foi traduzido enfaticamente por: falar coisa com coisa. infelizmente, como todas suas reuniões anteriores. Khá, khá, khá, reuniões judaicas... Você deveria ter ido e visto algo bonito. Ao chegar encontrei uma barulheira. O povo estava zumbindo como moscas! Deliberei então: para que ficar aqui, perdendo tempo ao falar com este bando de tolos?! E sem pensar muito fui direto ao assunto: Qual é o problema se o preço for de alguns centavos a mais? Ainda não é uma desgraça. Creiam-me judeus: desgraça maior seria se o coletor de impostos ficasse bravo e, Deus o livre, se demitisse! Creiam-me judeus, é assim! - Se você pensa que eu sabia o que estava dizendo, está enganado. Você precisava ter visto como alguns bonitos cidadãos, que se consideram inteligentes e experientes, fizeram cara séria e, cofiando as barbichas, concordaram comigo, franzindo tolamente a testa: - É bem verdade, é assim! Não tinham nada a dizer. Assim é assim... O resto do povo não tinha o que responder. Como se fosse coisa sabida, todos ficaram como que sufocados. Que alguém se desse conta e se questionasse: Por que é assim? Só um rapaz petulante, um bastardo sem vergonha, sobre o qual eu já lançara um olhar, não quis concordar e continuava argumentando: Não é nenhuma tragédia, ao contrário, ao contrário... Por acaso um coletor de impostos é obrigatório por lei? Tudo bem, sem um coletor de impostos também se vive neste mundo. Só os inteligentes e experientes cidadãos, que entendem 
do assunto, olhavam para ele como sendo um rapaz inexperiente, com quem não valia a pena falar e nem merecia a palavra. No entanto, ouça-me: quero resolver o caso do rapaz arrogante. Você, bom irmão, escreverá sobre ele uma carta de recomendação que só piorará sua situação, que o enxovalhará, jogando-o na sarjeta... Você sabe que tenho a mão pesada para escrever.

- O que não está entendendo, seu tolo! Está de acordo com um direito.

- Já quero ouvir, finalmente, como a reunião de hoje terminou.

- O que você não entende aqui, bobinho? Por acaso existe em algum lugar um povo tão bom e precioso como os judeus? Concordaram com tudo. Concordaram em elevar o preço mais alguns centavos além do que pedimos e se dispersaram muito satisfeitos. Eu, bobinho, certamente estou satisfeito...

- Claro Isser, que você pode estar satisfeito, porém...

- Porém, o quê? Seu bobo. Porém, o quê? Porém, é pena, você quer dizer, é uma pena para os pobres da cidade! Ora bobinho, vá, vá! Esta palavra vazia e sem sentido: pena! Pena, misericórdia, digo-lhe, são palavras inventadas por fracos, azarados, humildes que sentem sua fraqueza, que são inúteis. Não têm força e nem determinação para alcançarem seus objetivos, obterem tudo o que desejam; sentem que Ihes falta garra para lutar, não têm nem unhas nem dentes - por isso criaram a palavra: misericórdia. Tomaram-na como arma para gritar, pregar moral e pedir clemência, fazendo cara de coitadinhos. Pensam assim conseguir... Porém, camarada, é uma fraude, uma clara fraude! Entendemos essas apelações e a moral pregada por eles... Eu já aprendi, sou um cachimbo muito usado, um especialista, graças a Deus, na ordem do mundo, embora não seja um grande erudito. Não há necessidade de muito estudo. É suficiente um raciocínio razoável, um pouco de percepção para compreender o mundo. Ele é constituído por dois lados: de fortes e de fracos, de lobos, feras malvadas, e de carneiros, animais puros. Os primeiros tomam e os outros dão a pele. Não pode ser diferente. Troque a ordem dos fatores e 0 produto será o mesmo. Basta o fraco adquirir forças! Khe, khe, khe, para posicionar-se alto, virar o senhor feudal e se comunicar com as mãos. Basta 0 carneirinho ser dotado de garras e dentes afiados para esfolar a pele dos outros animais: experimente, por exemplo, dar aos azarados, aos que pedem 
clemência moral, um cargo na comunidade, na função de outro; basta que se sintam fortes, segurando a chibata, começarão a açoitar e estuprar com a *mão forte. Pegue um coitadinho, transforme-o em coletor de impostos: ele logo aprenderá a sugar, esfolar e extrair o tutano dos ossos. "Que Deus não permita que o mujique se torne proprietário de terra", diz

${ }^{\star}$ Beyad rome expressão hebraica que significa com a mão levantada e que denota desafio e despotismo. um provérbio sábio e verdadeiro. Qualquer mujique com um açoite sente-se poderoso. Continue com sua cara de coitado, com sua alma pura, carneirinho beato, pregue moral, xingue e clame o quanto quiser! Quando adquirir garras e dentes, juro, será mil vezes pior!...

- Deus o livre, Isser, que idéia a sua?! Não me refiro a misericórdia. Então agrada-lhe a palavra misericórdia? Eu penso, porém, em coisa totalmente diferente. Eu digo que você, Isser, pode ficar satisfeito. Tudo bem! Porém eu, eu!...

- Então fale, desembuche, bobinho! Então é assim! Você também quer ficar satisfeito? Desculpe, mas vá para o inferno... Estenda suas garras e você também poderá lamber o mel. Por Deus, você não está doente para concordar com a sua cidade. O diabo não o carregou. Amanhã, irmão, a comunidade tratará de uma nova série de medidas com que precisaremos arcar. Você entende? Nesta semana a porção semanal da Bíblia é "Trume", que trata dos impostos sobre produtos agrícolas. Quando teremos o capítulo "Shkolim" sobre os impostos devidos ao Templo?

Em outra ocasião em que conversavam, diante de um copo de vinho, num quarto muito asseado, Isser abriu a boca e começou a falar assim:

- Estou muito contente que tenha vindo, seu tolo. Fez bem! Tenho andado com o coração pesado e a cabeça cheia de pensamentos, como uma vaca com pústulas que latejam a ponto de estourar. Não aguento mais. Preciso, às vezes, abrir meu coração. Ver e ouvir tanto, e sempre calar-me, carregando tudo sozinho, chega a ser sobre-humano. Se eu não tivesse essa maldita mão pesada, juro que poderia aliviar-me no papel, escrevendo um belo "treatro"..., pela minha vida. Experimente este vinho, irmão! Ah, o que diz sobre ele? Recebi-o em troca de um favor.

- Muito bom o vinho, Isser... Por um favor, você diz; qual favor? 
- Ah, um negocinho! Uma decisão sobre Leml.

Leml, o tonto, solicitou-me um pequeno favor há muito tempo - como se eu fosse importante e conhecesse o segredo. Os tolos da cidade pensam que tudo depende de mim, que se eu quiser posso ajudar! Como alguns sub oficiais comem, às vezes, em minha casa o peixe sabático

${ }^{\star}$ Es vet helfn vi a toitn bankes, no original em idiche: ajudará como ventosas a um morto, significando ineficaz e inútil. porque sua alma anseia por um peixe judaico, os nossos bobos acham que eu sou íntimo deles, desde o pequeno ao grande, tanto do delegado como do chefe de polícia, todos irmãos! Pensam que tudo depende de mim. Que pensem! Que pensem e venham solicitar favores. Tenho sempre a mesma resposta: Veremos! Veremos! Falo com determinação. Você entende? Eles pensam que eu, Isser, estou me empenhando, que vi, embora tenha visto tanto como vejo minhas orelhas. Com isto levo minha parte. Se o solicitante não é atendido, eu não perco meu valor, nem minha energia. $O$ outro pensa assim: deixei de ganhar porque Reb Isser não quis olhar. Na verdade, se Reb Isser tivesse olhado, eu teria, com toda certeza ganho. Então, ele ficaria um pouco ofendido comigo e poderia vir me asfixiar ou me chamar do que quisesse, não importa. Minha reputação de homem influente eu não perderia. Ele fará as pazes comigo e quando precisar de um novo favor, responderei: Veremos! Veremos! Você entende, irmão? Para Leml dei a mesma resposta: Veremos! E à guisa de conselho sugeri saudar uns e outros, você entende? Onde se faz necessário... Eu vi muito bem que só meu olhar podia ajudar tanto quanto *ventosas a um morto. Leml, o tolo, porém, estava convencido que eu vejo e peço ao meu milionário para que também veja. Hoje, à tarde, na rua, você precisava ter visto como Leml e sua esposa fizeram uma festa para mim diante de toda a comunidade. De alegria até verteram lágrimas: "Reb Isser, paizinho querido! Alma querida! Antes Deus, depois o senhor, alma querida. Queremos agradecer-Ihe por termos conseguido resolver nosso assunto hoje. Se não fosse o senhor ter-se empenhado, nós, coitados, não teríamos conseguido. Vamos repetir para que todo o mundo saiba: só há um Reb Isser! Eu deduzi que só minha insinuação ajudou - Leml seguiu-a à risca. Você precisava ter visto, irmão, como me agradeceram. Eu só fiz um sinal como se dissesse: Ai! Quanto esforço e vida me custou seu negócio. Como me cansei até conseguir! 
- Leml mandou-me em seguida, em casa, um bom pagamento e algumas garrafas de bom vinho. E então bobinho, o que me diz sobre o vinho?

- Oxalá, Isser, só se tenha coisas assim a dizer sobre você, sobre os seus tolos e sobre toda a trapaça... Brindemos, saúde!

- Quero que você sufoque, seu tolo! Trapaça! Por que você chama isso de trapaça? O que são todos os assuntos, todos os negócios, todos os bens de cima a baixo, senão trapaças? Eu lhe garanto: todos os negócios! Até as coisas do mundo vindouro. Você entende? Qual a base para todos os negócios desde o começo até o fim? Talvez você pense que é a verdade. Não, irmão, verdade é só um dito, cada um tem a sua, a que lhe convém.

E para dar maior credibilidade a sua argumentação, Isser acrescenta:

- A verdade verdadeira não existe, nem poderia existir. Só prejudicaria nossas condutas, nossos negócios. Não seria um bom artigo. Milhares de escritórios, milhares de lojas, milhares de outras coisas, que você vê

*Torbes - no original, com 0 sentido de: cada um carrega seu fardo, liga-se à imagem do judeu errante. hoje em dia entre nós se desintegrariam como teias de aranha, sem deixar vestígios, nenhuma lembrança. Muitos ricaços estariam vagando com seus *sacos. Só Deus sabe como seria... Talvez tudo se fundamente em trabalho? Se é assim, você é um tolo! Trabalhar, trabalhar; um artesão trabalha, um lenhador, um aguadeiro e um carregador. Com trabalho ninguém ganha muito, mesmo que você se mate de trabalhar, você morrerá dez vezes ao dia de fome. Por exemplo, dedique-se aos negócios de um tolo, empenhe-se, transpire, corra, desgaste-se! Faça um acordo. Mesmo que tudo dê certo, qual será sua paga? Um pão do qual não sobra sequer um pedaço para ser abençoado! E se

${ }^{* *}$ Metáfora para incapacidade: nit kenen tzubindn a katz dem ek. não der certo, Deus o livre, você perde tudo. Torna-se um imprestável, um inútil, que não entende nada do que nossos sábios dizem, nem sabe **amarrar o rabo de um gato. Você tem peixe podre e arenque fedido... Não franza tanto a testa, irmão! Não estou filosofando, minhas palavras são simples. Filosofia não presta para nada. $O$ mundo detesta as pessoas muito inteligentes e com razão. Cuide-se como do fogo! Grandes figuras, pessoas cultas andam com calçados esburacados sem sola. Um pequeno homenzinho é bem melhor 
sucedido. Não é preciso ser muito inteligente nem eficiente. O principal é ter uma boca ágil, que saiba se virar para todos os lados quando é preciso, e uma língua sem ossos que vá para cá e para lá, uma lambida neste, uma lambida naquele. O importante é ter costas flexíveis para poder se vergar completamente... Quer dizer adular, ser hipócrita, mentir, mostrando sempre uma cara piedosa. O que fazer então? Dinheiro é necessário. Sem dinheiro você não é ninguém, menor que o mais ínfimo pequeno homenzinho. Você é pequeno e ordinário. O que é ser um miserável no mundo, irmão? Imagine como os ricos odeiam os pobres! Parece que às vezes até falam com eles e simulam misericórdia, mas na verdade não os suportam. Consideram-nos um estorvo. Para que perambula tal alma no mundo? Parecem-lhes uma calamidade, uma excrescência, uma carne esponjosa que lhes dá uma pontada no coração ao vê-los. Parecem-lhes que querem sua vida, seu dinheiro; que estão ávidos por sua alma - por seu dinheiro. Não tenho palavras para explicar-Ihe. Se você, irmão, é um pobretão, então morreu para o mundo. Seus antigos parentes, ao enriquecer, se afastam de você. Se alguma vez o visitam, parecem uma nova rica ao visitar o túmulo de um parente pobre, numa pequena cidade. Exibe-se com luxo, pérolas e diamantes para que os pobres a vejam e se orgulhem dela. Está no Pentateuco ou no Cântico dos Cânticos, parece: "o pobre equivale a um morto". Isto significa que o pobre cheira a defunto... Toda a sabedoria está no dinheiro. Se você tem dinheiro, tem o mundo: este e o vindouro. Atualmente, e como sempre foi, ter dinheiro consiste em ser um pequeno homenzinho, como você mesmo diz - adular, fingir, bancar o jogo... Saúde, bom irmão!

- Tenhamos saúde, Isser, e tenhamos também gente tão tola! E então, Isser, o seu ricaço, para quem você é a alma, o que ele vem a ser?

- Não quero falar sobre ele, entende, irmão? Desde que sou seu concessionário, não quero falar.

- O que significa, Isser, ser concessionário? Eis a novidade. Por acaso você tem um moinho, ou uma taberna da qual é o concessionário?

- O que Ihe importa, tolinho? Qual é a diferença? Um rico, um moinho, uma taberna, o diabo, o demônio? É tudo igual! O que importa é a concessão!... Hé, hé, hé, irmão! Você ainda é ingênuo, um aprendiz, um novato, penso eu. É preciso explicar-lhe tudo! E então, irmão, brindemos com 
mais um copo!... Agora procurarei fazê-lo entender, não será fácil. Você não *adoecerá por fazer conjecturas. Acompanhe-me, começaremos pelo moinho:

Água e vento são, no mundo, poderosas forças. Vem o homenzinho que quer fazer uso de tudo;

*Vest nit krank zain. Trata-se da amenização das consequências negativas por um empenho. constrói uma estrutura com rodas e pedras e consegue fazer o vento ou a água movimentar as rodas; as rodas movimentam as pedras, que por sua vez moem. Entendeu? Então, meu tolinho, sigamos em frente. O primeiro ${ }^{*}$ princípio da sabedoria é a força. Sobre ela se sustenta o mundo, com todas suas coisas. Um ricaço, como você sabe, é uma grande força. Todos se anulam diante do ricaço, tornando-se seu bode expiatório; todos se arrastam e se

${ }^{* *}$ Reishis khokhme: expressão hebraica no original, princípio da sabedoria. É também o nome de um livro de moral. humilham, mesmo sem receber absolutamente nada dele. Aqueles que não chegaram a receber nada, nunca receberão, nem um gole de água. Continuam se comportando da mesma maneira porque um rico é digno de honrarias e merece tudo. $\mathrm{E}$ eu, Isser, digo não! O que num rico se deve reverenciar é só o dinheiro, a utilidade que se pode ter dele. Você entende? Seu dinheiro é número um e ele próprio é número zero, um nada. Tal ricaço, digo eu, que não Ihe é útil, em absoluto, deve ocupar o lugar de um nada. Já que não é o principal, que vá para o inferno. Qual é sua importância? Não Ihe dê atenção e ***ouça-o como alguém do outro lado do mundo. Hoje você precisa saber mais. O esperto precisa fazer uso de tudo no mundo. Você entende? Agora repetirei tudo novamente.

- Pegue o copo na mão e repita com devoção, seu tolo: a força é a base de tudo. Um ricaço com muito dinheiro é uma força no mundo e o inteligente precisa saber usar todos os recursos. É preciso saber fazer uso do rico. Você acha que se deve simplesmente, de forma grosseira,

${ }^{* * *} \mathrm{Vi}$ in Tshernovitz di meguile - como na cidade de Tshernovitz se ouve a ladainha. Meguile é um longo rolo de pergaminho. Há cinco deles na bíblia que devem ser lidos e ouvidos por ocasião de festividades especiais. pegar o dinheiro, só o dinheiro? Não! É preciso saber erigir um moinho de vento para que ele, com sua força selvagem, gire as rodas para haver moedura! Ou é preciso diante dele ser como um comediante diante da comédia, ou como um cigano diante do urso. Você mediu a quantidade do seu centeio, então, moa com saúde no meu moinho! 
Se você, comediante, pagou pelo bilhete, participe de minha comédia e veja as belas apresentações! Ou se você, cigano, me deu alguns centavos, mandarei meu urso dançar para você. Você entende? Controlo o meu ricaço! Você quer ter acesso ao meu moinho de vento - dê-me uma medida, então. Eu sou o arrendatário. Você quer que se faça a comédia para seu divertimento, uma apresentação - pague-me antes pelo bilhete, eu sou 0 comediante. Talvez você queira que o meu ricaço se ponha sobre as patas, se estenda em todas as direções e ruja - dê-me antes alguns centavos, por favor, e de boa vontade serei eu o cigano!... Agora você entende, bobinho? Chega de estudar por enquanto!... Brindemos, bom irmão!

- Saúde, Isser, ao seu moinho! Saúde, saúde por sua comédia e por seu urso! Que suas rodas continuem girando, que sua comédia continue se apresentando e que o seu urso dance, dance, dance... 


\section{XVII}

Subentende-se que o método de Isser, sua visão de mundo, no início, eram inacessíveis para mim e muitas palavras eram apenas traduções. Eu nem sabia como se comia tudo aquilo. Porém, aquelas suas palavras de que ter dinheiro significa ser pequeno homenzinho, e pequeno homenzinho significa adular, ser hipócrita e enganar - isto captei de imediato. Aí já alcancei o âmago do segredo. Porém, entender exatamente o significado de adular, ser hipócrita, ainda não conseguia dominar bem.

Devo salientar que à época ainda não discernia bem entre o proibido e o permitido. Transgressão para mim consistia em olhar os sacerdotes enquanto abençoavam o povo, não realizar o ritual na véspera do dia do perdão, não atirar os pecados na água, cortar as unhas sem alternar os dedos, jogá-las fora sem acrescentar três pequenas lasquinhas de madeira do púlpito ou de uma mesa, para que intercedam no outro mundo no juízo final, como testemunhas adequadas, não acreditar em santos milagrosos, não acreditar em diabretes, não acreditar que mortos rezam à noite na grande sinagoga; não acreditar no purgatório, ou seja, que almas sob forma humana cumprem missões; que circulam entre nós fazendo negócios nas feiras, comprando e vendendo, hu-ha-hu!, e que são na verdade mortos, falecidos, coitados no purgatório. Não acreditar que nos julgamentos do rebe de Bezliudef eram trazidas almas, como recrutas, pelo anjo da guarda com um grupo de anjos punidores; não acreditar que o "próprio" rebe, que descanse em paz, era visita importante no céu. Para ele, daqui ao céu era um pulo. Tinha a chave das crianças, da neve e da chuva; não acreditar na reencarnação das almas em gado, animais e aves; não acreditar que um importante magnata reencarnou num porco, um outro, uma bela criatura, em asno, que Deus nos livre; um terceiro, um grande empreiteiro, num pássaro arrulhador, que Deus proteja as criancinhas judias, ou um dos proeminentes num peixe de voz estridente como uma enguia...

Resumindo, estes tipos de coisas constituíam, para mim, transgressões. Porém, adular, ser hipócrita, ser um pequeno homenzinho, não faziam parte da minha relação. E por que não ser, com boa vontade, um pequeno homenzinho? É-se rico e feliz, o que é bom. Ninguém ousa matar ou 
agredir um pequeno homenzinho. A agressão é muito dolorosa! Um alfaiate ou sua mulher quando dão um safanão, vêem-se estrelas diante dos olhos. Nem falar quando um khazn torce-lhe as orelhas; *perde-se a noção de tudo. Não é agradável estender-se no chão para colocar ou tirar as galochas de quem **faz pose. Juro que nada disto é agradável. Claro que eu tinha vontade de ser um pequeno homenzinho como os outros, livrar-me de vez das agruras e viver como todos aqueles, felizes, ricos e honrados. Por isso eu me empenhava com boa *Ken men yortzait
farguesn - esquecer o
dia do falecimento de
parente próximo. Este
dia é reverenciado
com rezas especiais,
às quais é dada muita
atenção, perdendo-se,
assim, a noção de
tudo. vontade em ouvir atrás da porta quando Isser Varguer falava com seu amigo. Ouvi muitas coisas que só vim a entender bem mais tarde. Com o tempo entendi mais e melhor que as aulas do Talme-Toire.

$\mathrm{Na}$ verdade, eu era um tonto desde jovem, muito bobinho. Porém, como concluí depois, eu não era

${ }^{* *}$ Zikh halth bai di zaitn un kukn tzu der stelie - Por as mãos na cintura e olhar para o teto. Denota descaso e arrogância, justificando a tradução por fazer pose. tolo por natureza, eu fui fabricado. A razão é desde a infância ter sido maltratado, perseguido e agredido. Fui alimentado com maldições, palavras grosseiras e feias, com palmadas, surras e golpes mortais. Quem quisesse podia investir contra mim e quebrar-me os ossos finos. Como diz o provérbio: de rezas não se engorda! De muito apanhar fica-se abatido, derrotado. Não é brincadeira, o quanto meu corpo franzino foi agredido. Eu, coitado, passo fome, frio, sinto-me desfalecer, pontadas me atormentam em toda parte, não estou bem - Ao invés de lamentarem por uma criança que se esvai, um ser criado por Deus bruxuleante como uma vela, só pele e ossos - ainda arrancam pedaços de carne e esfoliam minha pele. Picam-me e sugam-me... Eu estava simplesmente surdo e aturdido. Devo acrescentar que nasci na cidadezinha de Bezliudef. Um provinciano permanece sempre um provinciano. São pessoas diferentes, com outras sensibilidades, com outro gosto, outro aroma e outra cabeça. Não cheiram nem a peixe, nem a carne, são espécies únicas, sem mais comprovações. Não se surpreendam então, que um ingênuo, um tolo, como eu, pudesse cair alguma vez direito e raciocinar com método. Na verdade eu era um bobo e minha bobeira chamava a atenção, no entanto, ela não era natural; fui atordoado, agredido. Não me faltava um parafuso na cabeça, mas 
ela não havia sido trabalhada nem aplainada ainda. Isto era eu. Eu ainda poderia vir a aprender, a conjeturar e captar toda a sagacidade de Reb Isser.

Com Isser Varguer trabalhei durante muitos anos. Com o tempo fui me lapidando, compreendendo e sabendo tudo o que um pequeno homenzinho precisa saber. Eu prestava muita atenção e era perseverante. Eu já sabia enganar, ludibriar e, com artimanhas, fazer meus joguinhos. Meu maior prazer era jogar sujo, como se eu me vingasse dos outros mesmo sem motivo. *Jogava sujo por jogar. Escapar depois como um peixe dava-me a mesma satisfação de um estudante pobre de yeshive que descobre novas proezas na Guemore $^{45}$. Se há alguma boa consequência ou não, denota

*Opton oif terkish - realizar à moda turca, significando enganar com artimanhas, jogar sujo. uma boa idéia, um certo raciocínio. O sentimento de justiça e misericórdia nem chegou a ser despertado em mim.

"Justiça é como borracha que se deixa puxar e obedece quem a manipula. Pode ser dobrada de modo a se obter o que se deseja. Misericórdia é uma palavra inventada, uma fraude. Se você é mais fraco do que eu, você é um azarado, um inútil que quer me convencer alegando misericórdia!". Assim falava Isser Varguer.

Eu era um verdadeiro discípulo de Isser; me empenhava e me esforçava para agradar o mestre. Fazia tudo a seu gosto. Por isto o cativei e encontrei boa vontade em seus olhos. Como se diz, ele não me ${ }^{* *}$ criaria problemas.

Quando fiquei mais velho comecei a me

**Nemen a zak borsht - cobrar um saco de sopa de beterraba, significando cobrar uma ninharia. A expressão bilik vi borsht significa barato como sopa de beterraba, que havia com fartura na Europa do leste. Foi dado o mesmo sentido traduzindo por não criar problemas. analisar intensamente, perguntando-me: Quando começarei a fazer alguma coisa para me restaurar? O tempo vai passando - eu já sou um rapaz, louvado seja Deus, com a barba a despontar! Na verdade eu conhecia bem toda a ciência de Isser. Conheço-a com todos os detalhes. Porém, como dizia o professor do Talme-Toire - a arte não está no estudo, o principal é a ação - "o açoite".

Continuava pensando, pensando tanto até chegar à conclusão comigo mesmo: Ah, ah...! Seu bobo, digo para mim. O próprio Isser diz: "A

\footnotetext{
${ }^{45}$ Guemore - parte do talmude escrita em aramaico e concluída por volta dos anos 500.
} 
pessoa inteligente precisa fazer uso de tudo que existe no mundo. Precisa ganhar a confiança do ricaço a ponto de chegar a ser seu concessionário, representar com ele a comédia, fazer dinheiro com ele". Significa que o próprio Isser é uma força, então, erija um moinho para que ele, Isser, o gire! Pombas assadas voam em direção a sua boca e você, otário, clama por comida!..."

Para encurtar a história, comecei a adulá-lo. Procurei mil maneiras de sorrir-lhe, de entrar em seu coração e transformei-me em boa hora, em sua alma... Isser é também um ser humano que gostava de ser adulado e acarinhado, de ser admirado e invejado. Conhecia a essência e a utilidade da adulação. Ele mesmo, quando chamava alguém de sábio, bom, religioso, caridoso, puro e honesto, tinha a intenção contrária e queria dizer bobo, cruel, hipócrita, cão avarento, um ladrão entre ladrões, pupila dos olhos! Assim, parece, é no mundo; todos se deixam enganar, as pessoas gostam de se iludir. Mas não pensem que me foi fácil conseguir. "É fácil falar, difícil fazer". Demorou muito para que me tornasse importante para Isser. Talvez seja difícil para vocês entenderem, como um serviçal se torna importante? Não se ofendam, se é assim, vocês não conhecem o mundo! Quase todos os serviçais são importantes e quase todos os importantes são serviçais.

Quando as pessoas se inteiraram de minha importância, que eu era a alma de Isser, seu ilustre empregado, começaram a me agradar, a me cumprimentar cordialmente, como é a ordem no mundo. Este é o costume desde os seis dias da criação, no alto como no baixo. Na terra, quando se precisa do senhor feudal para alguma coisa, procura-se uma aproximação a seus ilustres empregados para agradá-los. Entabular uma doce e fluente conversa, para transformar-se em amigos íntimos e colocar-lhes algo na mão, pensando assim tapar-Ihes a boca, para não fazerem caretas, não acusar, nem ladrar. Ou então que eles soltem nos ouvidos de seus amos uma boa palavra constituindo assim advogados de defesa que podem vir a ajudar. O que um serviçal próximo consegue, pessoas importantes não conseguem. Ele conhece o coração de seus amos e omite deles coisas que não devem ser ditas... Se alguém precisasse de Isser - e quem não precisava? - recorriam à minha boa vontade para que eu intercedesse falando boas palavras sobre ele. Não confiavam só no que Deus quiser; davam-me dinheiro e presentes pensando já ter conseguido, pois eu falaria com Isser. Eu sabia que de nada adiantaria, 
como o próprio Isser dizia: "ajudará como ventosas a um morto". O que me importava? Que pensem e dêem dinheiro. Mesmo que eu me empenhasse, Isser tomará a sua própria decisão. O que será, será; assim ou assim. Isser pegará o dinheiro e falará, como seu costume: "Veremos, veremos, veremos!" Então do que adianta eu interceder? Por outro lado, o que me importa? Que pensem e dêem dinheiro.

Assim, desta forma, comecei aos poucos a crescer e acumular boa soma de dinheiro. 


\section{XVIII}

Como todos os serviçais emergentes, comecei a ter prazer em vestir-me e enfeitar-me. Eles gostavam de se empetecar o quanto podiam e andar com correntes brilhantes, botões e anéis. Gostavam também que seus calçados brilhassem como espelho para arrancar os olhos do mundo e que o mundo se admirasse e se maravilhasse. Aos sábados enfeitava-me como um *lorde e passeava com meus amigos para exibir-me e assombrar o mundo. Queria observar as moças e jovens senhoras que passeavam aos grupos. Eu conhecia todas as empregadas

*Tok, no original, significa boneca e na cultura brasileira mudaria o sentido intencional do autor, justificando-se a tradução por lorde. da cidade e sabia várias histórias sobre as jovens senhoras, entre as quais eu tinha muitas conhecidas.

Num sábado, "shabes nákhmu", enquanto passeava com meu grupo pela cidade, onde abundavam moças judias com vestidos de seda e de veludo, enfeitadas com pérolas e todo tipo de jóias, veio em minha direção uma moça trajando um vestido muito simples de algodão, limpo e bem passado. Seu rosto resplandecia como a estrela matutina e ofuscava as demais em suas pérolas e diamantes. Elas se assemelhavam a velas diante do sol. Acompanhava-a um jovem elegante, alto e de bom porte. Sua beleza ocupoume os olhos e eu fiquei parado, confuso, durante algum tempo, sem ver nem ouvir nada a meu redor. Um pouco mais tarde, quando me recompus, não mais a vi. Misturou-se às demais pessoas e desapareceu como uma estrela cadente numa noite de verão. Sua imagem ficou incrustada em meu coração. Desde aquela hora não mais a tirei da cabeça. Seu rosto sempre se desenhava diante de mim, bem como sua figura. À noite, no escuro, brilhavam seus olhos ardentes como duas estrelas no topo do céu. Eu tinha a sensação de que a conhecia há longo tempo, que já a vira em minha vida, não me lembrava de

**Guepikt in kop - picava na cabeça, que foi traduzido por afligir. quando e nem de onde. O esforço em lembrar e não conseguir é muito triste, que para ser sentido é preciso ter passado por semelhante situação. Isto me atormentava, ${ }^{* *}$ afligia-me um pavor de enlouquecer. Prometi a mim mesmo descobrir quem era a moça e onde morava. 
Uma ocasião, ao anoitecer, eu perambulava através de uma ruela lateral, quando o céu azul ficou carregado de negras nuvens que começaram a relampejar em flamejantes listras. A ruela estava quieta, não havia viv'alma e eu caminhava pensativo e melancólico. De repente, ouvi um grito de cortar o coração - à minha frente corria alguém, como um ladrão, com um pacote na mão, querendo escapar. Parado! Dei um grito impedindo sua passagem e batiIhe com meu grosso bastão. Ele se assustou muito, deixou cair o pacote, fugiu correndo e sumiu. Perto de mim havia uma pessoa estendida ao lado de uma cerca. Corri até ela com o pacote e ela permaneceu imóvel. Escureceu devido a nuvens pesadas que apareceram no céu. Levantei às pressas a cabeça da pessoa tentando reanimá-la. Começou a relampejar seguidamente e vi à minha frente um par de olhos ardentes. Senti uma pancada no coração. A cabeça começou-me a rodar e fiquei parado, muito confuso. Eu a reconheci - Era ela!...

Ela me contou, então, que vinha caminhando sozinha pela rua, quando alguém, num salto, arrancou de suas mãos um pacote com camisas que ela acabara de pegar para costurar, derrubando-a com um soco. Com lágrimas nos olhos, ela me disse que se eu não a tivesse socorrido teria ficado sem seu ganha pão e com o nome sujo. Ninguém mais the daria trabalho de costura. Agradeceu-me de todo coração, suas faces estavam rubras e a cada olhar brilhante seu sentia-me estar pegando fogo, meu coração estava na iminência de derreter como cera.

- Deus the pague! Disse-me ela com a voz trêmula e queria seguir seu caminho.

- Não, não! - Respondi-lhe agitado - Não a deixarei sozinha, de jeito nenhum. Acompanhá-la-ei até a sua casa.

Ela hesitou em concordar. Era-lhe embaraçoso deixar-se acompanhar por um estranho. Sem deixá-la falar, peguei o pacote de camisas e andamos rapidamente pelas ruelas através das quais ela me conduzia. Não trocamos uma palavra sequer, todo o caminho. Olhava-a de soslaio e

${ }^{*}$ Kadokhes no original, com o significado de febre e atualmente, com o significado de malária, ou a febre intermitente da doença. Foi traduzido por : tremia como vara verde. eu tremia como *vara verde. Toda vez que ela tocava em minhas mãos querendo tomar-me seu pacote para que eu não tivesse o trabalho de carregá- 
lo, sentia meu corpo ser atravessado por uma onda gelada, o sangue coagulado nas veias e quase perdi o fôlego. Só paramos ao atravessar um portãozinho de quintal onde com letras escuras, numa placa clara, lia-se: Golde Jacobsohn - costureira.

- Jacobsohn! - Exclamei admirado, lembrando-me de Jacobsohn que me tirara de uma encrenca no caso do khazn, quando *fiquei desnorteado e onde eu comera nos dois dias de ano novo.

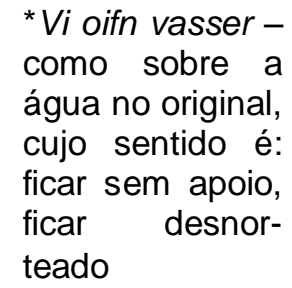
como sobre a água no original, cujo sentido é: ficar sem apoio, ficar desnorteado

- Sim! - Responde ela - Eu sou Golde Jacobsohn. Do que se admira?

- Conheci seu pai há muito tempo! - Respondi-Ihe - Ele me ajudou numa época difícil.

- Meu pai faleceu há alguns anos - Disse ela com um suspiro profundo.

- Lembro-me da senhora, quando ainda era uma menina pequena! - Disse com um sorriso, encarando-a como se já a conhecesse um pouco.

- Assim! Muito prazer! Pela minha vida!

Antes que nos despedíssemos, ouviu-se uma trovoada e um temporal desabou. Convidou-me para entrar e aguardar a chuva passar. Aceitei com prazer. A chuva foi bem vinda! Por mim poderia cair um dilúvio que nunca cessasse, assim eu ficaria em sua casa, junto com ela, como na arca de Noé.

A casa era constituída de um só cômodo dividido por um biombo. Uma metade era o dormitório e a outra, a sala de estar. Notava-se de relance que moravam pessoas pobres, não preguiçosas, nem relaxadas. Havia algumas cadeiras velhas e um sofazinho, revestidos de algodão amarelado. Encostada à parede havia uma cômoda coberta por uma toalha branca como neve sobre a qual alguns objetos estavam expostos: alguns vasinhos de porcelana com flores vermelhas, dois cálices azuis lapidados, uma caixinha pintada, um espelho, algumas garrafinhas de perfume; estes eram os únicos enfeites da casa. Acrescentem-se vasos de plantas nas janelas, e um quadro bordado em seda com Moisés e as tábuas da lei. Perto da janela havia uma mesa de trabalho com tecidos e linhas e todas as outras coisas relacionadas ao trabalho. 
Golde apresentou-me à sua mãe, uma judia magra e fraca, que aparentava cerca de cinquenta anos, contando-Ihe todos os detalhes de nosso encontro. A mãe agradeceu efusivamente, convidando-me para sentar. À mesa estava sentada uma pequena menina de oito anos de idade que se ocupava com costura e não parava de me encarar com olhos furtivos. Golde também sentou-se à mesa e abriu o pacote que trouxera. Eu também estava sentado, quieto, sem articular uma palavra sequer, como um noivo, olhando com satisfação para as claras mãozinhas ativas de Golde. Meu coração exultava.

Ficamos alguns minutos em silêncio, para depois começarmos a falar sobre o tempo, como a chuva é necessária. A mãe de Golde repetiu várias vezes que não era chuva que caía, mas sim pão, e que o preço da farinha após a chuva, provavelmente baixaria alguns centavos. Golde, a um sinal da mãe se retirou. A velha ficou conversando comigo sem parar até mencionar a doença do marido, que descanse no paraíso, doença que se estendeu por algum tempo durante o qual gastaram todas suas reservas. Ao morrer deixou uma pobre viúva sem apoio com duas meninas para criar. Porém, Deus, bendito seja ele, abençoou-a com uma filha como poucas há no mundo. Sua Goldiniu é boa e devota, tem todas as qualidades. Trabalha dia e noite, costurando e tricotando, esforçando a vista sobre a agulha, para conseguir o sustento. Vivem com amargas dificuldades. Seu penoso trabalho mal dá para as necessidades básicas, porém vive-se, que Deus me perdoe. O que seria sem sua Golde?! Só Deus sabe...

- Com certeza devo me alegrar e valorizar este presente dado por Deus, no entanto, meu coração chora por vê-la trabalhar tanto, diz a mãe com um forte suspiro e lágrimas nos olhos. - Como me dói o coração vendo-a trabalhar por nós todos, coitada, dá a sua saúde, a vida, e não se permite gastar um centavo consigo própria. Às vezes lhe imploro - Goldiniu, minha alma! Tenha misericórdia de sua vida, compre algo para seu deleite e descanse um pouco, alma minha.

Ela responde jocosamente:

- Não preciso de deleite, mamãe! Não tenho tédio no coração. Que se divirtam aqueles que ficam de mãos cruzadas e não sabem o que lhes falta. Para descansar temos o glorioso dia de sábado! Assim ela responde 
sempre e continua quieta em seu trabalho, como uma *pomba. ${ }^{\star *}$ Que suas preocupações recaiam sobre mim...

Durante a conversa entrou Golde trazendo quatro copos de chá numa bandeja, colocando-a sobre a mesa.

Quando terminamos o chá, a chuva tinha cessado e Golde mandou a irmãzinha ir para a cama dormir.

- Vá, Sheindele! - Disse ela acariciando sua cabeça. - Já é hora para você. Assim acordará amanhã mais bem disposta. Seu professor não virá mais hoje.

Sheindele beijou a mãe e a irmã, deu boa noite a todos e foi dormir. Para mim também chegara hora de ir. Levantei-me, despedi-me e saí.

A meia lua brilhava como um barco dourado navegando num mar azul, plácido, calmo e quieto. O céu olhava para baixo, com milhares de estrelas brilhantes, como um noivo apaixonado, para sua terra querida, vestida de relva verde, engalanada com bonitas flores de doces aromas dos mais caros perfumes. Os sapos coaxavam alegres nos

${ }^{*} \mathrm{~A}$ pomba é citada como referência na cultura judaica por sua fidelidade familiar. riachos e, de algum jardim, um rouxinol respondia, causando inveja aos melhores cantores... Meu coração também cantava alegre e eu nem mesmo conseguia identificar o que. Já próximo de casa tomei consciência que era a melodia que Leizer, o alfaiate, costumava usar durante os rituais nupciais de cobrir a noiva. Com um "vá para o inferno", xinguei, de brincadeira, o alfaiate e com um sorriso alegre reforcei meus votos de "vá para o inferno".

Atentem para a história! Apesar do feliz encontro, sonhei a noite toda coisas tristes: lamentavam-me com lágrimas e vozes emergiam das profundezas da terra gritando - Socorro, o que tinham contra nós?!... 


\section{XIX}

Comecei a me tornar um frequentador assíduo na casa de Golde. Eu me sentia atraído como um ímã. Não era uma atração devido às suas boas qualidades, como era pura e dedicada no sustento da mãe e da irmãzinha! Não! Essas coisas um aprendiz de Isser não sabia avaliar. Só o dinheiro era a medida para a avaliação das qualidades de um ser humano - o prato da balança. Inteligência, eficácia, qualidades morais eram para mim os atributos de uma pessoa rica que gozava a vida em luxúria. Como ele o conseguiu e às expensas de quem ele vive - absolutamente não importa. Nestes detalhes entram com cálculos somente pobres e azarados, motivados por invejas e ofensas, bem como para caluniar os outros, disfarçando os próprios defeitos. Justificam, assim, sua ineficiência, inabilidade e azar e consolam-se perante 0 mundo por sua pobreza devido a seu bom caráter, que Ihes impede de serem pessoas falsas e vis. Não! Não eram as boas e lindas qualidades de Golde que me agradavam, porém o seu lindo rosto despertava em mim uma paixão selvagem e grosseira. O que significava esta paixão eu sozinho não conseguia atinar - eu procurava somente uma aproximação. No início trazia-Ihe trabalho, encomendei camisas e punhos e depois continuei indo como um bom conhecido.

Eu costumava encontrar lá aquele jovem rapaz que acompanhava Golde naquele passeio sabático. Ele se sentia muito à vontade na casa, como um parente íntimo. Ele dava aulas para Sheindele, ajudava nos afazeres e costumava trazer do mercado coisas úteis, sempre que necessárias; às vezes, chegava também a emprestar, até mesmo dar dinheiro em tempos ruins. Tratavam-no por você, chamando-o simplesmente pelo nome - Mikhl.

Mikhl era um escritor que costumava ensinar meninas e meninos a escrever, conseguindo assim um parco sustento. De uma conversa com a mãe, deduzi que Mikhl era um esteio para a família em diversas ocasiões difíceis. Ele era um parente distante e quase noivo de Golde. Por enquanto não era de conhecimento público, porém, ela esperava, com a ajuda de Deus, em breve, fazer um noivado, quebrando um prato. Estas palavras apunhalaram-me até a última costela, no entanto consegui disfarçar, como se não me importasse. 
Comecei a ver em Mikhl um inimigo, que se antepunha em meu caminho e a quem eu precisava derrotar. Comecei como um gatinho a me insinuar com doces palavras tanto à Golde como a sua mãe, brincava com a menina e trazia, com frequência, caramelos e jogos, na esperança de me tornar importante desbancando Mikhl. Uma ocasião, tentei oferecer dinheiro, quando percebi certo aperto na casa, porém, com um sorriso, Golde recusou. Isto foi pior que um tapa ensinando-me polidez e aumentou meu ódio a Mikhl. Meu interior ardia de raiva em um fogo infernal que eu dissimulava muito bem, fazendo uma cara alegre e falando com doçura. Naquele tempo eu já sabia fingir muito bem, pois era o primeiro aprendizado de um pequeno homenzinho. Quando Isser resolvia acabar com alguém, costumava tratá-lo muito cordialmente, corria para recebê-lo com alegria e beijo na boca. O beijo da morte deve ser dado gentilmente, sem ruído... Segundo nossos sábios escolhese para o amigo uma linda morte, uma morte quieta, onde não se ouvisse nem um canto de galo... Assim falava Isser Varguer!

Eu costumava me apresentar bem vestido e bem penteado com brilhantina, para cair nas graças de Golde, em detrimento de Mikhl que se trajava simplesmente. Porém, Golde não se impressionava com roupas bonitas e insinuou delicadamente que a brilhantina podia fazer mal e provocar resfriado. Mikhl sorriu e meu sangue ferveu... Uma vez Sheindele chegou a dizer:

- Que horror, Mikhl! Como você está mal vestido! Reb Itzik Avreml está esplêndido: arrumado, de cabeça lavada, com faces e lábios radiantes!

- Bobinha! - Mikhl respondeu calmamente - O que posso fazer se sou pobre, não estou bem empregado e não tenho o suficiente para tudo?!

A mim parecia que Mikhl me agredia com suas palavras chamando-me de empregado e queria me humilhar. Engoli meu orgulho, mordi os lábios e não retruquei uma palavra.

Desta forma passou todo o verão e parte do outono. Quase não conseguia controlar-me de tanto amor. Porém, não havia o que fazer. Mikhl estava entalado em minha garganta como um osso. Percebi que se não me apressasse em extrair o osso, sufocaria. Aproximava-se o tempo em que Mikhl deveria ficar noivo de Golde. A velha gostava dele como de um próprio filho e 
ansiava pelo dia em que ele se ligaria a sua filha definitivamente. Falava com frequência sobre os preparativos necessários e todos na casa estavam satisfeitos. Sheindele pulava de alegria, brincava e provocava Mikhl, para finalmente abraçá-lo com ambas as mãos. Golde os observava com olhos úmidos e brilhantes, que demonstravam muita satisfação e corava como fogo. Não dava para encarar seu rosto tão radiante como o sol, de tão bonita que ela estava. Aparentei uma expressão cordial como de uma pessoa da família que se apraz quando há festa em casa. Em meu coração, porém, ardia o inferno. Saindo de lá eu rangia os dentes e jurei a mim mesmo descobrir um meio, o mais rápido possível de livrar, para mim, o caminho até Golde.

Não demorou muito e o meio veio de encontro às minhas mãos. Quando vieram à nossa cidade em busca de recrutas, consegui, em silêncio, através de Isser, que Mikhl fosse convocado para o exército!...

Quando cheguei à casa de Golde, encontrei um clima de luto. A velha estava doente acamada, derrotada, com a cabeça envolvida por um lenço molhado. Golde estava pálida como a parede com os olhos inchados e vermelhos, cuidando da mãe. Tinha os cabelos desalinhados. Estava preocupada, triste e abatida. Sheindele estava irreconhecível, sentada encolhida num canto, cabisbaixa. À minha entrada todos romperam em prantos, derramando lágrimas quentes sem palavras, como desconsolados que acabaram de encontrar o melhor amigo.

- O que aconteceu? - Perguntei eu como um tonto, ficando paralisado.

Por alguns minutos não houve resposta, depois a velha falou com uma voz chorosa, embargando-se com as próprias lágrimas: Ai de mim! Mikhl... Não há mais Mikh!!... Os aliciadores o levaram!... Ai de mim!...

Ela rompe novamente num choro copioso. Golde está sentada na cama, a seu lado, inclinada com as duas mãos sobre o rosto. A mãe doente põe a mão sobre sua cabeça e todas choram, lamentam e pranteiam como a um morto. Faço uma cara triste, suspiro e gemo, pró forma; meu coração está eufórico ao encarar Golde, para a qual tenho agora o caminho livre. Devoro-a com os olhos, encarando-a de alto a baixo, como um lobo encara um cordeirinho para o qual afia os dentes. E penso comigo mesmo: Tudo bem! Você será minha, não escapará às minhas garras... 


\section{$\mathbf{X X}$}

Passaram-se alguns meses, Mikhl foi entregue ao serviço militar, levado para bem distante de onde não se retorna assim depressa. A casa de Golde estava em ruínas; tudo transpirava luto e desolação. Os vasos de plantas estavam murchos porque ninguém se importava em regá-los. Os enfeites sobre a cômoda não estavam dispostos artisticamente como outrora, mas cobertos de poeira acumulada, especialmente o quadro de Moisés. Ele parecia melancólico e olhava, de sob o vidro, com muito ódio e raiva. A mim, pelo menos, parecia; eu evitava encará-lo... Sheindele parou de estudar, não tinha mais com quem brincar. Ela estava definhando, emagrecera, apagava-se como uma vela, deixou de ser criança. Golde tornara-se cinzenta. Nunca mais esboçara um sorriso. Estava amargurada e desinteressava-se de tudo. A velha encarava as filhas, deplorava acenando com a cabeça e banhava-se em lágrimas. Estava cada vez mais abatida precisando ficar acamada de tempos em tempos.

Comecei a frequentar a casa mais seguidamente. Ficava lá enquanto Golde trabalhava. Eu procurava encorajá-la com doces palavras ternas e penetrar em seu coração cada vez mais, consolando-a. Comecei a observar na casa um amargo desamparo. Por mais que Golde se empenhasse em seu trabalho com dedicação e esforço, o que ganhava não era suficiente para as necessidades diárias porque seu pagamento era muito baixo. $A$ ausência de Mikhl comprovava obviamente como ele era útil à pobre família. Faltava agora sua ajuda. À época Golde não conseguia muito trabalho e para a constante necessidade de manipulação de remédios para a velha não havia dinheiro. Intercedi sugerindo a Golde que aceitasse minha colaboração financeira. Golde enrubesceu, baixou os olhos e não respondeu nada. Percebia-se que ela estava muito inquieta e que pairava um vento assustador de sentimentos amargos. Expliquei a ela que seria a título de empréstimo durante determinado tempo, somente, e ela devia aceitar por sua mãe doente, que necessitava de remédios para poder sobreviver. Neste exato instante, a mãe deu um gemido profundo, deitada em sua cama e Golde, ofegante e com as mãos trêmulas e geladas, aceitou o dinheiro que eu the oferecera. Colocou um xale às costas e rapidamente saiu de casa... 
Uma noite, em meu quarto, deitado na cama não conseguia dormir, o sono me abandonara. Meu amor por Golde me maltratava, não me deixava descansar, então, comecei a pensar sobre qual poderia ser 0 desfecho. Até quando sofrerei assim, sem dar um ponto final! Como resolver? Casar então? Para mim não convinha por vários motivos: o principal é que eu precisaria deixar de trabalhar para Isser e isto implicaria abdicar de ganhar dinheiro fácil; deixar uma vida feliz, sem tristeza, sem cansaço e dor de cabeça, postergando todas minhas esperanças; o que eu receberia dela? Nada! Ela se encontrava nua no mundo, assim como nasceu. Ela teria muitos filhos, fedelhos que me aborreceriam, eu acabaria comendo o pouco dinheiro amealhado e me tornaria pobre, um inútil, um imprestável para qualquer coisa no mundo; sofreria e acabaria me tornando o mesmo miserável que fora durante a juventude. E para quê? Apenas por amor!... Isser, assim pensei, caçoaria muito de mim.

"Amor não é nada além de um rostinho bonito, de uma bolha de sabão, que apresenta diante dos olhos todas as deslumbrantes cores do arco íris e, de repente, se desfaz sem deixar vestígios. É uma brincadeira, uma ninharia, que deve ser conseguida também por uma ninharia, bastando não ser bobo. Amor - é apenas uma fachada, sob a qual as pessoas se deixam enganar umas às outras, durante certo tempo. É uma teia elaborada artisticamente para capturar homenzinhos fracos e que se desfaz como a neve, tão logo seja aquecida..."

\section{Assim falava Isser Varguer.}

Convém não ser tolo e alcançar meu objetivo de forma rude? Isto, porém, estava fora de questão. Conhecendo Golde, eu sabia da impossibilidade até de pensar sobre isto. Suas atitudes eram tão dignas, que ela devia ser respeitada. A língua não ousava articular em sua presença uma palavra má. Uma vez escapou-me uma observação pouco adequada que teria passado despercebida para outros, que não Golde. Ela fez tal careta que me anulou completamente e um calafrio percorreu todo o meu corpo. Não! Mulheres como Golde não se deixam convencer, enganar... Mesmo que se tenha a astúcia de dez demônios. Devo então cuspir todo o romance e esquecê-la? Isto, porém, estava acima de minhas forças. Eu renunciaria antes à minha vida do que a ela. $\mathrm{O}$ amor pode ser um jogo, como diz Isser, do qual 
eu não podia me desfazer. Refleti, voltei a refletir e cheguei à conclusão: não havia alternativa a não ser casar! Isto poderia prejudicar meus interesses?! Precisava chegar a uma solução que conciliasse aqui e ali. Casar o quanto antes era imperativo. Eu não aguentava mais sofrer! Basta! Golde precisava ser minha!... Com este pensamento adormeci logo e tive bons e doces sonhos.

Acordei um pouco tarde e tomei a decisão de declarar-me a Golde ainda hoje, mesmo que *chovessem canivetes. Era véspera da Páscoa e Golde precisava fazer dispendiosos preparativos para a festa. Isto me favoreceria. Encontrei-a sozinha debruçada sobre o trabalho. A velha estava deitada na cama, atrás do biombo, e Sheindele perto dela. Só se ouvia ruído de

${ }^{*}$ Es zol afile dunern un blitzn - no original, significando: mesmo que trovejasse e relampejasse, que denotariam empecilhos. A opção de tradução foi o uso da expressão brasileira: chover canivetes. tosse, ora da mãe, ora da pequena. Ambas ofegavam, alternadamente, como se estivessem competindo numa prova de ofegantes. Um grilo emitia um som estridente que se compunha com o ofegar das doentes, num macabro concerto. Golde estava preocupada, costurava freneticamente sem se permitir levantar a cabeça por um instante.

Eu iniciei uma conversa pregando lições de moral, censurando-a por trabalhar acima de suas forças, perdendo a saúde, sem misericórdia sobre si mesma nem sobre sua família, que dependia inteiramente dela e não de seus bons amigos. À família sua saúde era muito preciosa a ponto de darem a vida por ela... Diante destas palavras, Golde lançou-me um olhar impossível de ser descrito. Continuei falando de forma emocionada, com grande ardor, até formular minha proposta, que ela me era mais cara que a vida e que eu me sentiria extremamente feliz em me casar com ela. Golde deixou cair a agulha de entre os dedos, ficou confusa apoiando a cabeça sobre ambas as mãos. Calei-me por alguns minutos, fiquei encharcado de suor e meu coração disparou como se eu tivesse atravessado uma montanha muito alta.

A tosse ofegante atrás do biombo ficou cada vez mais intensa. $O$ vidro quebrado da janela sacudido ritmicamente pelo vento entrava em ressonância com a melancolia de todas. ${ }^{* *}$ Abriuse-me a boca. Voltei a falar calorosamente, falei, falei tentando convencer Golde. Descrevi sua situação atual, como

** Uso do reflexivo enfático é característico da língua ídiche. estava oprimida de todos os lados. Apontei para a mãe fraca e doente, bem 
como para Sheindele, que sofriam, coitadas, e extenuavam-se. Nem que fosse só por elas, Golde devia concordar. Comigo seria bom para todas e, se Deus quiser, todos viveremos felizes e satisfeitos, que tanto Deus com os homens ficarão contentes. Golde encarou-me atentamente e cálidas lágrimas caíram de seus olhos em grandes gotas como pérolas.

- Por favor, dê-me um tempo! - suplicou Golde, como alguém que se encontra numa aflição. - Preciso pensar, trocar idéias com minha mãe e, então, dar-lhe-ei uma resposta clara.

No dia seguinte, ao vir a sua casa, encontrei-a junto à mãe doente, atrás do biombo. A velha tomou-me as mãos e mostrando-me Golde com a cabeça, disse-me que terá muito gosto em entregar-me seu precioso brilhante, seu tesouro, seu presente de Deus; porém, que eu saiba como apreciá-la e valorizá-la. Ela acrescentou um item: eu deveria demitir-me do emprego, porque apesar de ser uma pessoa importante, eu não passava de um empregado; para ela, bem como a seu marido, o pai de Golde, de abençoada memória, e a toda a família, não seria uma honra entregar sua filha a um empregado. Opus-me à solicitação argumentando que não seria sensato demitir-me de um emprego de ouro, que me rendia muito e onde eu poderia me tornar gente, na verdadeira acepção da palavra.

- Pessoas bem relacionadas - respondo eu com empáfia - vêm a meus pés, invejam-me atualmente e, se Deus quiser, me invejarão ainda mais no futuro. Tudo bem! Já sou bem relacionado com todos eles. Porém, a esta altura é errado demitir-me, é um pecado. Por enquanto, sob todos os aspectos, é melhor eu permanecer com Isser, mesmo após o casamento. O que importa? Suponham que eu sou um lojista e permaneço o dia todo na loja ou um comerciante e viajo durante a semana. Aos sábados, feriados e dias de folga virei para casa. Por enquanto será assim, e amanhã, Deus dirá. Com

${ }^{*}$ Mishteins guezogt ou nishteins guezogt, no original significando: infelizmente. Inclui uma depreciação sobre o assunto abordado. Provávelmente originário do idioma polonês, onde tem o mesmo significado. certeza será correto... Se não fica bem, se the é embaraçoso perante o mundo um empregado, faremos o casamento discretamente, sem pompa, sem barulho, sem algazarra. Precisaremos nos conformar de não ter todos os bens relacionados no evento, sobre os quais *não vale à pena falar! Pobres coitados! 
O desfecho foi minha argumentação ter sido aceita e o acordo ter sido firmado.

- Mas lembre-se! Cuide bem de meu tesouro, respeite minha filha, minha alma querida! - A velha tornou a pedir chorando. Golde e Sheindele também choravam e soluçavam. Eu estava no auge da alegria por ter sido capaz de realizar meus desejos, à minha moda.

Num bonito dia de "Lag Boimer" viajamos todos para uma pequena aldeia e na presença de um quorum de dez homens foi celebrado um discreto casamento.

${ }^{46}$ Lag Boimer - 33ํ dia após o início da Páscoa, quando se interrompe a tristeza e compenetração das sete semanas que antecedem a entrega das "Tábuas da Lei". 


\section{$\mathbf{X X I}$}

No início, logo após o casamento, tivemos eu e Golde um tempo feliz. Todos, em casa, estavam contentes. Mantinha-me, como antes, na casa de Isser de forma muito estável, desempenhando minhas funções agradavelmente, mais ainda do que antes. Em nenhum instante deixava de pensar que por ser casado eu precisava de dinheiro. Eu ficava repetindo mentalmente todos os princípios para ser um "pequeno homenzinho", com todas as explicações de Reb Isser e também com minhas próprias observações, que como um estudioso excepcional eu acrescentara com inteligência e perspicácia. Que o mundo perceba, a partir de agora, que grande estudioso, que jóia, que peça completa eu sou, que perceba bem que tenho mulher e despesas, precisando então de muito dinheiro. Que o mundo me dê dinheiro e pague minhas contas. Tudo bem, o mundo não está doente e o diabo não o carregará! Assim deliberei comigo mesmo e elevei os preços de todas minhas tarefas, as quais passei a desempenhar com muita dedicação.

O magnata de Isser, o grande urso, dançava no papel principal da super comédia de Isser, e o próprio Isser dançava como um ursinho em minha infracomédia. Ambos tínhamos muita fartura. O tolo público vinha pedir-nos, em todas as oportunidades, para fazermos, para ajudarmos, usando nossa influência e pagavam bastante. Fazíamos o seu jogo e ambos estávamos satisfeitos. Fiquei ávido por dinheiro. Por mais que ganhasse achava insuficiente. Ansiava pela moeda.

$\mathrm{Na}$ minha casa vivia-se com muita avareza. Eu costumava economizar, poupar o máximo possível e ficava muito bravo se se gastasse um tostão supérfluo. A velha ficava amuada e às vezes retrucava que eu costumava contar os grãos de cereal na panela e que concedo com má vontade a porção de cada um. Eu também reagia carrancudo respondendo que é fácil fazer caridade com o chapéu dos outros; se eu recebesse comida de graça, eu também não seria avarento. Estas argumentações faziam mal a Golde, ela chegava a ficar lívida e frequentemente acabávamos discutindo. Numa ocasião fomos tão longe que eu cheguei a brigar feio com ela, ofendi-a de modo grosseiro, xinguei-a como um lacaio sabe xingar e saí de casa furioso, batendo a porta. Fiquei uma semana ausente. 
Meu antigo amor ardente foi se esfriando com o tempo. O lindo rosto de Golde tornou-se um rosto comum, onde eu não via mais que dois olhos e um nariz. Golde perdeu, para mim, o viço, aparentando uma mulher vulgar, como as outras. Do fundo do meu coração, arrependi-me por ter casado. Para que isto me servia, pensava com meus botões, arcar com tamanho fardo, sustentar toda a família que me devora a cabeça e me consome? Foi uma hora diabólica em que me deixei levar por um rostinho bonito, tendo despendido tanto dinheiro com isto. Onde estavam meu raciocínio e minha compreensão? Eu mesmo fiquei perplexo com a tolice que cometera. Calculava quanto esta tolice me custara e como seria mais rico se não a tivesse cometido. Estas considerações foram piorando minha atitude. Eu recriminava tudo e todos. Encarava todos de forma enfezada e não falava direito com ninguém. No decorrer de alguns anos Golde padeceu bastante, comeu o pão que o diabo amassou, engoliu tudo sem dar um pio. Chorava sem fazer barulho.

Justo naquela época precisou ocorrer a morte repentina do grande milionário, o todo-poderoso, para quem Isser era a alma, acarretando a paralisação do moinho de vento - as rodas não podiam mais rodar!... Com a morte do milionário, meu reb Isser se torna ex-alma e eu, por consequência exex-alma, rompem-se os laços. As pessoas se deram conta, arrefeceram e com o tempo deixaram de procurá-lo com solicitações. Além do mais, a velhice já havia se aproximado e ele foi se exaurindo, ficando senil. Não tinha mais a aparência, a inteligência e o raciocínio de outrora. Como Isser deixou de ser importante, também eu perdi minha importância; era considerado uma moeda que perdeu seu valor, uma carta fora do baralho.

*Ikh hob im azoi guehert vi in Tshernovitz di meguile - Eu o escutava como a ladaínha de Tshernovitz, que já foi comentada em páginas anteriores. Significa que não lhe dava atenção, não o ouvia mais.

Para Isser eu continuava importante, ele não perdera a consideração por mim. Como, porém, ele deixou de ter utilidade para mim, perdi todo o interesse por ele. Ele me servia como noventa mil coisas inúteis.

*Eu não o escutava mais. Segui os próprios conselhos de Isser Varguer que eu recebera outrora e sem muito pensar, abandonei-o como se abandona uma carcaça. 
Um ser *morto não causa uma impressão tão triste como um quase morto, que ainda manifesta sinais vitais. Me refiro a mim, bem como, a muitas pessoas, como por exemplo, um ex-arrecadador de impostos, um intermediário ofendido, um ativista desativado, um religioso pouco importante e todo o tipo de ativista comunitário enfraquecido e destituído. Tudo bem, uma carcaça é uma carcaça morta que não precisa de nada. Refiro-me àqueles que não estão mais em função e perderam seu ganha pão, que durara por longo tempo; eles são mortos vivos que ainda querem comer e beber um trago e que ainda precisam de tudo, mas não conseguem se mexer; são grandes inválidos amargos, Deus o livre para vocês, têm boca, mãos e pés que não os servem daqui para ali!...

Esses mortos vivos partem nosso coração, só de olhar para eles, tão azarados e tão fedidos, com o perdão da palavra!

Depois que saí do emprego passei a fazer

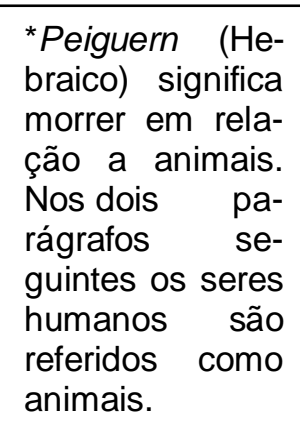
parte deste tipo de seres. Não sabia o que fazer, a que me dedicar, porque além da função que desempenhei como pequeno homenzinho, não conhecia nenhuma outra e eu nem servia para nada. Minha situação estava muito ruim. Eu vivia de minhas reservas. Trocava dinheiro por comida. A cada moeda trocada, caía-me um pedaço de carne, eu perdia partes de mim. Estava sempre furioso. Não era indulgente com ninguém em casa, provocando cada um. Para cada centavo dado a Golde, para as despesas, eu sugava seu sangue dizendo: O que querem de mim? Não posso sustentar uma tal família!

Fiz a velha comer terra; ela ficou tão mortificada, que adoeceu gravemente, não deixando mais a cama. Percebia-se que seu fim estava próximo, que não duraria muito. Confesso, agora, que lhe desejei a morte e fiquei satisfeito pela iminência de uma boca a menos e uma despesa menor. Fingi estar preocupado com sua doença e ter ficado transtornado. Não fiz economias nem com médico, nem com farmácia - contanto que fosse apressada a sua partida... Atendi-a como um filho dedicado, passei noites à sua cabeceira dando-Ihe os remédios e pensando: Quando virá o anjo da morte para levá-la? Fui enaltecido por todos devido à minha dedicação. Esqueceram até os sofrimentos que eu Ihes impingira. Golde insistia para que eu deixasse de velar sua mãe e fosse descansar, o que eu me negava a fazer. 
- Vá você - Eu lhe respondia - Você, coitada, precisa descansar um pouco. Eu ficarei bem, velando sozinho.

Lembro-me agora, assustado, daquela noite de inverno, quando a velha estava confusa com os olhos esbugalhados proferindo palavras ininteligíveis e seu coração roncava terrivelmente, emitindo o som de madeira sendo serrada. Golde estava sentada perto da cama, mais morta do que viva, com os olhos vermelhos e torcendo as mãos. Sheindele, a pálida, a magra, a ressequida Sheindele, observava a mãe agonizante, observava e soluçava, observava e tossia horrivelmente. De repente a mãe se sentou, olhou suas filhas e suspirou profundamente.

- Eu lhe peço... - Disse ela com voz fraca, encarando-me durante um minuto, com um olhar penetrante que atravessou todos meus órgãos Peço-lhe, tenha compaixão de minhas filhas! Elas ficam, coitadas, solitárias como uma pedra - órfãs de pai e mãe, sem parentes, sem um salvador... Vou deste mundo tranquila, ficarei em minha tumba tranquila, se você prometer solenemente e cumprir...

Novamente deu um suspiro, pôs uma mão sobre a cabeça de Golde e a outra sobre a cabeça de Sheindele e abençoou-as com uma voz quase inaudível. Ambas as filhas choravam copiosamente e debruçaram-se sobre a mãe que as abraçava e beijava, apertando-as junto ao coração. Caiu sem forças sobre a cama, voltando o rosto para a parede; deu um ronco profundo e adormeceu para sempre...

Golde e Sheindele emitiram tais lamentos e gemidos de comover uma pedra. Eu cobri meu rosto com ambas as mãos e - com dor, vergonha e horror, digo-o agora - sorri contente, como se tivesse tirado uma carga pesada de cima de mim.

A velha foi, por enquanto, minha segunda vítima. Mais tarde deveria cair minha terceira vítima - a magra e ressequida Sheindele!... 


\section{XXII}

Com o tempo comecei a me aborrecer de ficar em casa de braços cruzados, deixando mofar a dádiva, a grande aptidão de um pequeno homenzinho que havia dentro de mim. Era um pecado, eu juro, desperdiçar tal aptidão, deixar apodrecer esta dádiva, tornar-me um lixo durante o esplendor de minha juventude, ainda com todas as forças?! Eu ainda poderia fazer os melhores negócios, nadar em ouro!

Por acaso existe só Tsvietshitz, a minha cidade, no mundo? Eu pensei comigo mesmo. Não há mais cidades com judeus, onde minha mercadoria teria saída? O mundo, bendito seja Deus, é grande. Há outras cidades judaicas. Judeus são judeus em todos os lugares, com uma mania, com um caráter, e manda-chuvas, milionários judeus existem também, benza Deus, como lixo. Com certeza eles se deixam levar, são os arrendatários e pode-se fazer com eles o jogo! Para que vou desperdiçar minha vida, apodrecer nesta casa, consumir meu pouco dinheiro e sofrer depois dificuldades, transtornos e aflições como outrora? Quando me lembro, tremo e meus cabelos se põem em pé! Não, decido eu, não posso mais ficar aqui! Enquanto sou jovem e ainda tenho um pouco de dinheiro, preciso tentar a sorte e me deixar ir.

- Adeus! - Numa bela manhã disse eu a Golde, que estava grávida, e saí mundo afora.

*Glupsk é o melhor lugar, é a cidade que mais me atraiu. É uma grande cidade judia, com muitos bobos, que se deixam conduzir pelo nariz por qualquer um, e qualquer um empina seu nariz e vai na frente, julgando ser um costume judaico imutável. Glupsk é uma cidade com muitas associações e muitos presidentes, com todo o tipo de judeus religiosos e todo o tipo de belos judeus.

*Um dos modelos estereotipados de shtetlekh criados pelo autor. É a cidade dos tolos, embora seja um centro dinâmico, com atividade comercial. Tem a tolice como mentalidade.

E Deus alimenta desde os búfalos com chifres até as lêndeas dos piolhos e supre o sustento de todos os tipos e criaturas com dignidade. Em síntese, Glupsk logo me encantou, era tudo o que eu pedira a Deus. Glupsk foi para mim o que a lama do pântano é para o sapo, onde ele pode coaxar e gozar seu domínio. 
Àquela época eu devia ter vinte e três ou quatro, ou quem sabe, talvez vinte e cinco ou seis, ou mesmo vinte e sete anos. Eu não contava minha idade e como muitos judeus entre nós naquele tempo, eu não sabia quando tinha nascido; isto também não estava escrito. Assim é melhor porque o dia do nascimento, entre os judeus não é comemorado. Para que serve? O dia do falecimento, sim, o judeu sabe. Comemoração de aniversário parece estranhamente selvagem. Eu tinha dinheiro e isto facilitou ficar conhecido entre as pessoas importantes de Glupsk. Eu costumava dizer que pretendia constituir um negócio, embora na verdade eu só esperasse por uma concessão. Eu não servia para mais nada. Toda minha intenção era conseguir fazer uma aliança com o maior milionário da cidade e fazer com ele a comédia, como Reb Isser o fizera, uma vez, com seu ricaço.

Como vocês sabem, o milionário de Glupsk ocupava lugar de destaque na província. Seu poder não era brincadeira. Tanto quanto era grande, era grosseiro. Gostava de se dedicar a bobagens, de ficar sabendo todas as bisbilhotices, tudo o que se passava dentro da casa de cada um. Tudo isto servia para mim como sob medida. Eu necessitava de uma pessoa assim. Percebi que com uma força como ele, podiam-se girar as rodas e virar o mundo. Porém, como chegar até ele? Como ganhar sua confiança? O único jeito é me tornar um deles, um autêntico morador de Glupsk. Me integrar, me amarrar entre os seus seguidores. Comecei a pensar muito a respeito.

O tempo foi passando e eu fui ficando mais conhecido. Casamenteiros ficavam a meu redor como um enxame de abelhas. Determinaram que eu era viúvo. De onde tiraram a conclusão, eu não sei. Por eu ser homem e estar sozinho, sem mulher, achavam que eu precisava e queria casar. Não supunham outra alternativa. Caíam sobre mim como gafanhotos com propostas de casamento. Eu costumava ouvir atento, com um sorriso e pensando comigo mesmo que não me faziam mal as conversas sobre noivas; era um prazer ouvir falar sobre moças bonitas. Quem falava? Judeus religiosos. Eles elogiavam sua beleza, sua finura, exaltavam suas qualidades e lambiam os dedos com muito desejo e entusiasmo... Tudo bem, pensei, esses judeus podem falar até estourarem, a quem importa?... Os casamenteiros distribuíram-me em pratinhos e fizeram minha fama em toda a cidade: que eu era muito rico, entupido de dinheiro, bem relacionado, inteligente, eficiente - 
enfim - gente. Tenho boa lábia, além de ser uma preciosidade, sou calmo, tenho um coração judaico e qualidades de ouro. Tudo bem, eu pensava. Podem falar, podem falar, crianças judias; tomem um gole e falem o máximo que puderem!... Um dos casamenteiros sugeriu-me uma proposta na qual não havia muito dinheiro, porém muita estirpe, com famoso relacionamento, único no mundo.

Tratava-se de pessoa importante com um nome quádruplo: Reb lossef Markl, filho de Reb Monish Leibl. Estava embebido em aristocracia, provinha da família do legendário Rebe de Glupsk. Jamais colocara a mão em água fria, nunca trabalhara, vivia bem devido a sua importância e casara bem sua prole. Deus o abençoara com muitas filhas, magras, morenas, feias e além de tudo desmazeladas, porém as casara adequadamente. Ricos como, por exemplo, lacaios emergentes, novos ricos pequenos homenzinhos ansiavam para conseguir parentesco com Reb lossef Markl, filho de Reb Monish Leibl, a fim de granjear relacionamentos. Assim que uma de suas filhas completasse catorze ou quinze anos já havia um pretendente, que se antecipava a outros, com o intuito de fazer um grande negócio, pagando-lhe muito bem. A moça que me caberia era mais escura e mais feia que suas demais irmãs, com uma carinha chupada, miúda, magra como um figo seco!... Em comparação a Golde era uma perfeita macaca. O casamenteiro não encontrava nela nenhum defeito, a seus olhos ela tinha a graça judaica. Assim falou ele:

- Não importa que ela seja um pouco escura, ou o que mais? Quem valoriza estas ninharias? Que diferença faz para um judeu: um pouco mais escura, um pouco mais clara? Dá na mesma, acredite-me! O principal é o investimento... Isto deve ser levado em conta. E que este investimento é bom até um cego pode perceber.

É óbvio que sorri para o casamenteiro! Contudo gostei de ouvi-lo e a idéia não me saía da cabeça. Meus olhos se abriram e percebi que o único caminho através do qual poderia obter concessões para alcançar a felicidade, seria através deste casamento. Reb lossef Markl, filho de Reb Monish Leibl, era um proeminente ativista religioso intrometido, presidente de várias instituições, muito considerado pelo milionário que teria por ele muito respeito, aconselhando-se com ele em relação a assuntos judaicos. Então, se eu me tornasse seu genro, logo poderia conquistar a confiança do milionário e fazê-lo 
dançar com admiração. Eu teria fartura, entraria nos milhões e viveria feliz, melhor do que jamais imaginara! Mas, ai, e o preço a pagar? Ela é feia! De fato, que diferença faz! O que eu tinha da cara bonita de Golde? Tudo é bom com pão...

Lembrei-me de Golde. Tive grandes aborrecimentos. Ela estava pendurada sobre meu pescoço como uma corrente, dominando minha alma. Insultei-a mentalmente imaginando como me livrar dela.

$\mathrm{O}$ casamenteiro fazia seu trabalho entrementes. Atormentava-me dizendo que se eu não me apressasse outro pretendente tomaria de minhas mãos esta oportunidade única; eu me arrependeria depois. Deixei-me convencer e o casamenteiro, com muita eficiência, providenciou um encontro entre mim e o pai da moça, não sem antes exaltar minhas *qualidades e elogiando-me mais que numa cerimônia fúnebre. Tudo

*Harim ugvaot - em hebraico, significando montanhas e vales. O autor usa uma metáfora para altura e grandiosidade. bem, tudo bom, mas a única exigência do pai da noiva é que eu não tivesse tido filhos do primeiro casamento. Não queria que crianças estranhas sobrecarregassem sua filha. Eu lhe garanti que não tinha filhos e 0 casamenteiro, de sua parte, confirmou,jurando por tudo que the era mais sagrado inclusive por sua parte no mundo vindouro e outros juramentos assemelhados... Firmamos um acordo com um aperto de mão, postergando o noivado para outra data. Comecei a pensar, carinhosamente, em como me livrar de Golde, de maneira discreta, sem alarido. Que não se ouvisse nem o canto do galo. 


\section{XXIII}

Decorridas três semanas após o acordo, de tardezinha, uma carruagem pára defronte à casa de Golde. Um vento frio soprou fazendo cair de algumas árvores folhas amarelas, que sobre a terra cochichavam tristemente provocando uma profunda melancolia. Da carruagem desceu uma pessoa que se aproximou lentamente da porta, ficou parado durante um tempo como se the fosse desagradável encostar na maçaneta. Essa pessoa era eu, com minha própria honra.

Ao entrar na casa, meu coração disparou, e eu fiquei junto à porta, sem fala. Golde encontrava-se sozinha, sentada no chão, num canto, com o rosto apoiado sobre uma cadeira, como se estivesse cochilando, sem ter percebido minha entrada. Sobre a janela queimava uma vela de sebo com uma chama vermelha, ao lado havia um copo com água e um pedaço de tecido. Entendi logo o significado de tudo e fui assolado por vários sentimentos. Lembrei-me da primeira vez que aqui entrara; que alegre, que bonito parecia tudo; uma pobre família vivia aqui muito satisfeita! Todos se amavam e acalentavam esperanças para um porvir pleno de felicidade. De repente me introduzi, como um gato num ninho de pombas alegres e felizes e acabei com tudo. Mikhl desaparecera sem que se soubesse onde se encontravam seus restos mortais, a velha mãe e Sheindele empurrei para a terra, e agora queria dar um fim a Golde, devastar sua vida para sempre...

Avancei um passo. Golde como que acordou e encarou-me, por um instante, confusa. Seu rosto pálido, que deixava transparecer o grande sofrimento por que passava, bem como seus olhos inchados que revelavam seu amargo estado de ânimo, despertaram em mim, por um instante, um sentimento humano de misericórdia e involuntariamente perguntei:

- Como está, Golde?

- Uma estimada visita, eu juro! - Disse Golde com um profundo e amargo suspiro, olhando em minha direção. - Após tanto tempo sem se pronunciar, ele se lembrou e veio fazer uma visita de pêsames a sua esposa. Veja você mesmo como estou, sentada de luto... Ah, Sheindele! Ah, Sheindele... 
- Golde! Retruquei, sem saber o que falava. Fiquei muito confuso e emocionado com suas últimas palavras proferidas, com tanta tristeza, que até uma pedra se tocaria.

- Desolada e funesta é minha vida. Eu preferiria a morte, se não fosse ele... Venha! - Disse Golde, mais docemente levantando-se do chão e conduzindo-me, atrás do biombo, até um bercinho, onde dormia um bebê; as duas mãozinhas fechadas sobre o rosto, que pareciam esboçar, de tempos em tempos, um leve sorriso. - Eis por quem eu quero viver! - Seu rosto adquiriu, então, mais vida.

A criança abriu de repente os olhos e começou a sugar um dedinho, emitindo sons infantis e fazendo movimentos característicos. A mãe olhou-o com carinho, esquecendo seu sofrimento por instantes. Remedando a fala infantil disse:

- Veja, filhinho, quem se encontra aqui! Apresento-Ihe, com amor, a sua visita! É seu papai!...

De repente, meu sangue começou a ferver. Eu dera a minha palavra de que não tinha filhos e agora via meu *herdeiro, que não me serviria para o negócio. O sentimento de misericórdia logo se foi e eu permaneci retesado com um rosto zangado, encarando a infeliz criança, coitada, que começou a fazer caretas e gritar fortemente.

*Kadish no original.
Trata-se de uma ora-
ção antiga da liturgia
judaica de louvor e
exaltação a Deus, es-
crita em aramaico. É
proferida por ocasião
de morte de parentes
próximos. Filhos têm
obrigação de rezá-la
por seus pais
falecidos. Assim a
opção de tradução foi
de meu kadish por
meu herdeiro.

*Kadish no original. ção antiga da liturgia judaica de louvor e exaltação a Deus, escrita em aramaico. É proferida por ocasião de morte de parentes próximos. Filhos têm obrigação de rezá-la por seus pais falecidos. Assim a de meu kadish por meu herdeiro.

- Quieto! Quieto! - Falou, carinhosamente, Golde. - Quieto, bobinho! Está com medo de seu papai? - Enquanto ela se inclinava para atender o bebê tirei do bolso a papelada jogando-a rapidamente em suas mãos e disse:

- Eis aqui, para você, o meu divórcio!...

Golde ficou terrivelmente confusa, como se tivesse levado uma pancada na cabeça, arregalou os olhos sem proferir palavra.

- Ouça Golde! - Disse-lhe - Como a história está, você não é mais minha mulher, não há mais nada entre nós. Porém, se você não for tola, não fizer nenhum escarcéu e conservar consigo a criança, não a abandonarei, mandando, de tempos em tempos, algum dinheiro. 
Diante destas palavras Golde desatou numa risada estranhamente selvagem. Pensei que ela tivesse saído de seu juízo. A risada selvagem transformou-se num amargo clamor:

- Fora! - Berrou ela para mim assumindo uma expressão de orgulho. - Você, malvado, não merece ficar um instante nesta casa, onde viveram pessoas direitas outrora e que se foram desta vida, por sua causa. Fique tranquilo, não perseguirei uma pessoa como você. Tenho vergonha de dizer quem eu tive como marido. Você pode casar-se sem medo! Eu e meu filho não precisamos de sua ajuda! Enquanto eu viver ganharei honestamente com meu trabalho para as nossas necessidades! Fora daqui! Esqueça que teve um filho. Rua!! Fora daqui!...

Me esgueirei rapidamente da casa, deixando a cidade naquela mesma noite. 


\section{XXIV}

Meu sogro, Reb lossef Markl, filho de Reb Monish Leibl, foi uma preciosa chave que me abriu todas as portas das grandes personalidades de Glupsk e revelou os segredos de toda camarilha da cidade. Seus relacionamentos e sua estirpe serviram de alavanca para que eu me tornasse um belo judeu, um presidente de instituições e metesse o nariz em assuntos comunitários até obter a concessão do magnata de Glupsk. Naquela época, comecei a ficar um manda chuva da cidade. Fiz o jogo com o meu urso, conforme a teoria de Reb Isser Varguer, e os judeus pagavam em dia por todas as farsas. Eu via claramente as palavras de Isser: "Um povo tão precioso, tão bom, tão dourado e tão ingênuo, como são os judeus, não há no mundo inteiro"...

Minha confissão Ihes possibilitará entender um décimo de um décimo de minha filosofia de vida e que norteou meu comportamento:

1 - *Pelo pecado que pequei sendo um pequeno homenzinho - Uma expiação, eu disse, a todas as profissões do mundo. Delas não se pode engrandecer-se, fica-se rebaixado, reprimido, sempre por baixo, o bode expiatório. Que os outros trabalhem, eu quero respirar, ser um desocupado, viver bem.

${ }^{*}$ Al khet shekhatati, em hebraico, que significa pelo pecado que cometi. São as primeiras palavras e 0 nome de uma reza que é dita no Dia do Perdão, pedindo desculpas e perdão pelos pecados cometidos, batendo-se no peito com a mão como sinal de lamento, deploração e arrependimento.

$$
2 \text { - E pelo pecado que pequei pela concessão - minha }
$$
concessão, uma ocupação fácil e muito lucrativa, bloqueou meu coração. Eu não acreditava em verdade, em honestidade, em misericórdia, em amizade e em nenhum outro bom sentimento humano. Eu só reconhecia aquilo que me servia, que me era útil e espoliava tanto pobres, como viúvas e órfãos, o quanto pudesse. Se um pobre chorasse, jorrando rios de lágrimas, não me importava. De que me servem as lágrimas, pensava eu nesse ínterim, é melhor dar-me dinheiro! **"Dê-me a fortuna e pegue as lágrimas", em hebraico. "Cachorro, dê dinheiro e afogue-se nas

${ }^{*}$ Está em hebraico no original, em confrontação com a expressão seguinte, que está em russo. Evidencia-se o desnível linguístico!

próprias lágrimas", em russo. 
3 - Pelo pecado que pequei em massacrar à toa - Não se deve corromper, e eu corrompi. Tomei um ricaço, uma criatura de Deus, com dois pés e um rosto, uma figura humana, e transformei-a num urso domesticado.

4 - E pelo pecado que pequei contra o animal dócil - Todos os judeus, em geral, olham na boca dos ricos querendo que eles concordem com tudo que eles, judeus, fazem. Em todo seu comportamento: em sua religiosidade e coisas de crença, na forma como educam os filhos, em sua vida pública e privada. Em todas as manifestações se percebe, obviamente, 0 gosto, o paladar e o caráter do referido ricaço. Ou seja, todos os comportamentos locais da cidade, bons ou ruins, inteligentes ou tolos dependem do tipo de pessoa que é o ricaço local. Por isso quando eu esbocei a meu ricaço, o animal domado, tolas caretas adequadas à questão, eles se assumiram, de fato, como animais e, coitados, comportavam-se como tal. Quanto mais tolas, melhor, mais judaicas. Um bobo começou a ter valor, mais ainda um ignorante. Este subiu de posição... Eu, ai de mim, olhava com satisfação para os mais bobos. Eu na qualidade de comerciante de gado, os encarava como mercadoria e com o coração alegre avaliava o lucro que poderia usufruir deles.

5 - Pelo pecado que pequei pelo descobrimento de instruções e leis - Juizes, analistas das leis e professores mantive em minhas mãos, eles eram obrigados a fazer tudo que eu mandasse, aprovar coisas estranhas sobre as quais nunca se ouvira ou se soubera. Eles proibiram o permitido e o que era puro tornaram impuro, tudo como me convinha. Eles não podiam criar problemas para mim por medo de perderem seu sustento. Grandes galinhas galgas, por exemplo, os coitados dos juízes precisaram proibir alegando serem um tipo de águia. Qual a razão? Eu mandara porque tinha um acordo com os coletores de taxas, aos quais não servia as pessoas comerem galinhas com tanta carne sem taxa extra, pois seu abate era equivalente ao de galinhas pequenas.

6 - E pelo pecado que pequei por meio de palavras - por denúncias. Se por acaso não gostassem de minhas determinações na cidade, não poderiam perceber a terrível fraude, com que se ilude o público; como ele é enganado e conduzido pelo nariz em grandes atoleiros, até o pescoço. Pessoas que contestassem, eu e minha turma, providenciávamos um feitiço 
dizendo um *Shir Hamales", uma denúncia, calandoIhes, assim, muitas bocas.

$$
7 \text { - Pelo pecado que pequei fazendo }
$$

**"abra-cadabra" - truques de mágica com o aro ou tirava dinheiro da parede, fazia bolotas de neve atirando-as na goela das pessoas; ficava de longe e

*Leitura dos salmos de 120 a 134 visando neutralizar os contestadores através de elogios ao Criador. Inclui palavras cabalísticas com poder de proteção.

pegava um bocado, fazia de preto, branco e do branco, preto. Fazia de tolos, sábios e de sábios, tolos. Pegava os peixes antes de caírem na rede. Fazia caretas e demais truques. Os mais famosos mágicos não conseguiam fazer o que eu fazia.

8 - E pelo pecado que pequei nas eleições.

${ }^{* *}$ Hocus-pocus, no original, terminologia usada na época naquela região.

Aqueles predicados necessários para desempenhar um cargo, como por exemplo: honestidade, compreensão, raciocínio, falar e escrever - que teriam aparentes utilidades para a cidade eram para mim e minha camarilha, defeitos. Eu necessitava de pessoas sem aparência para o mundo, inúteis para a cidade. O que servia para a cidade não servia para mim. Eu precisava de desajeitados, inúteis nos quais eu pudesse por arreios e conduzi-los ao meu bel prazer, que vendessem suas almas por centavos e fossem submissos e aduladores, adulando-me a mim e a toda minha turma. Como o público de Glupsk era muito tolo, como uma criança pequena, e deixava-se conduzir pelo nariz, por isso durante a escolha de delegados ou para o cargo de um rabino e demais situações, eu decidia por pessoas grosseiras, subordináveis, inúteis, que causariam danos à cidade depois. O que sabe uma criança? Uma criança tola não sabe calcular e prevenir o amanhã. Ela está ansiosa em obedecer em troca de pequenos subornos, basta adoçar-Ihe a boca com um pouco de vinho, com um docinho ou com um brioche... Se depois tiver cólicas, com certeza the doerá. Meu público, minha criança, não chegava a receber o suborno. Padecia e enfraquecia.

9 - Pelo pecado que pequei contra as instituições - De instituições de caridade eu sempre gostei pela vantagem que oferecem. Seus voluntários adquirem fama e prestígio como caridosos, protetores da religião, humanitários, além de um bom dinheiro. Meu sogro alcançou o título de "administrador dos fundos secretos", isto significa que o dinheiro comunitário estava em suas mãos, com extremo sigilo, e ninguém, além dele, sabia onde 0 
dinheiro ia parar... Eu também fiz parte de muitas instituições com o título de fiel, um daqueles voluntários em que se confia plenamente: não precisava prestar contas a ninguém. Todos nós, cada um em seu estilo, pegamos fortuitamente e tudo ficava encoberto...

10 - Pelo pecado que pequei pelo imposto. - A taxa sobre a carne ou a "caixinha" é um lugar sujo e hediondo, onde há percevejos, vermes e demais tipos de rastejantes; dela saem aqueles tipos de homenzinhos, aqueles tipos de demônios que corroem a cabeça e provocam desgraças. A taxa é uma calamidade, um flagelo, que se faz sentir em todos os interesses judaicos e tem uma parcela de culpa em todas as misérias. Devido à taxa, judeus estão doentes, magros e sofrem de amarga fraqueza que passa por herança, de geração em geração. Através da taxa acha-se um pretexto de como sempre espoliar o público. Cada centavo da taxa atrai, como um ímã, mais centavos judaicos, que são acrescentados, subindo cada vez mais seu valor até transformar-se em um monte de dinheiro. Toda a cobrança possibilita a emersão de grupos que ludibriam as pessoas e as enganam com tolices. Todos os jurados de Deus, intrusos, metidos, coniventes e prestadores de favor obtêm seu sustento, sugando a vida dos pobres com bondade e religiosidade aparentes. Muitos pequenos homenzinhos obtêm força e poder para fazer tudo o que querem, e o que Ihes convém. Eu próprio, ai de mim, fui um destes homenzinhos, que sugavam o leite das taxas, defendendo-as sempre com unhas e dentes porque eu conhecia o segredo, enquanto houver cobrança de taxas, os judeus permanecerão na diáspora, nas mãos destes homenzinhos, como eu e toda minha camarilha incutindo-lhes medo, como em crianças pequenas, conduzindo-os com bobagens e fazendo com eles tudo o que queríamos. Eu era a favor da taxa e ela me favoreceu, sustentando-me. Comia de graça a melhor e mais bonita carne, enquanto os pobres pagavam caro e roíam os ossos. Eles eram os cordeiros e eu o lobo. Eu mordi, estrangulei e suguei muito sangue judeu em minha vida...

11 - Pelo pecado que pequei pelo temor de Deus. Todas as falsidades creditei ao temor a Deus. Eu fazia todos os meus atos em nome de Deus, eu reivindicava a defesa de Deus defendendo também seus judeus, para que permanecessem sempre iguais. Para mim e minha camarilha era melhor os judeus permanecerem bobos e deprimidos, por isso, dá para entender que 
eu não favorecia situações inteligentes em que eles pudessem abrir os olhos. Aparentemente, pelo temor a Deus, eu me fazia de ingênuo e empenhava todas minhas forças para manter as mínimas bobagens; eu era falso e meu temor a Deus tinha aquele sabor... Se adviesse uma coisa boa aos judeus, eu a nomeava de decreto e envidava, eu e minha turma, todos os esforços para anular o referido decreto. Que crianças judias, por exemplo, aprendessem a escrever e calcular para no futuro poder ganhar seu sustento com dignidade, isto para nós constituía um decreto. Que os judeus se vestissem bem deixando de ser repugnantes com aquelas feias roupas que outrora seus inimigos lhes impuseram também era um decreto... Se por acaso existe uma hipótese de anulação da taxa também era considerada um decreto. Entrementes, não perdíamos dinheiro com os decretos, ao contrário, fazíamos bom negócio e vivíamos, em algum lugar, muito bem, até hoje em dia. Nós, pecadores de Israel, ganhávamos bastante dinheiro dos desajeitados usuários de solidéus.

12 - E sobre o pecado que pequei com a camarilha e os outros em geral, caluniando, mentindo, delatando, ambicionando, ocultando, intermediando; usando comédia, hipocrisia, maldade, difamação, fraude e obtenção de favores, nas pequenas casas de oração e oficinas. O significado de todas estas coisas é óbvio e eu os poupo de mais explicações. 


\section{XXV}

Como já disse anteriormente, eu não era por natureza tolo ou bobo; eu fui rebaixado e negligenciado, então devo ressaltar que no fundo não era tão vil e infame, porém, eu fui levado. As grandes desgraças pelas quais passei no mundo e também a filosofia de Isser me empederniram o coração tornando-me um perverso. Depois de cometer maldades tinha sensações desagradáveis, às vezes, que me agulhavam por um instante, um instante somente, passando logo depois. Peguem Gutman, por exemplo! Um homem tão corajoso, honesto e bondoso, que me acolheu tão gentilmente - ouçam só - dele e de todos como ele, eu fugi como se foge da peste.

Se chegasse até mim alguém, como ele, com livros, eu o teria trapaceado como ao pior inimigo. Da minha parte era de fato uma maldade, pela qual eu mesmo passara, e por isto mesmo eu tinha que perpetrá-la. Eu não conseguia de outro modo.

"Aquelas pessoas que escrevem livros jamais deveriam ter nascido! Coitadas delas. Elas devem ser odiadas e evitadas como o fogo! Elas pretendem penetrar nos outros provocando desgraças com suas descrições e palavras mordazes. Com tudo elas se contentam, para elas tudo é *esférico e contundente. É um milagre que o asno não tenha chifres e tais chatos não tenham dinheiro, um centavo sequer e são, bendito seja Deus, miseráveis e desvalidos. Ainda bem que necessitam de nossos centavos, caso contrário seria ruim. A única solução para que estes percevejos não mordam tanto, é tampar-lhes a boca com vinténs e, simultaneamente, eliminálos". Assim dizia Isser Varguer!

*Kailekhdik un shpitzekhdik - no original, cuja tradução é: esférico e pontudo. Haveria aí uma incongruência, porém, o segundo termo pode significar também agressivo, afiado, incisivo e sagaz. A escolha de tradução recaiu sobre contundente:

A palavra de Isser, para mim, era a lei!

Tudo isso, porém, aconteceu quando meu mau instinto por dinheiro era ainda muito forte. Eu absorvia tudo como uma esponja. O espectro da pobreza com todos seus sofrimentos e agruras estava sempre diante de mim. Não havia lugar em meu coração para bons sentimentos. Eles passavam como um raio, desaparecendo em seguida. Mais tarde, porém, quando eu já possuía bastante e estava saciado, o pavor pela pobreza foi colocado de lado e 
o instinto do mal enfraqueceu. Aí, então, meu adormecido instinto do bem começou, discretamente, a aparecer do fundo do meu coração com um pouco de moral, primeiro contido, quieto, palavras contadas, que com o tempo foram aumentando em número e volume, cada vez maior e mais iradas, censurandome. Certas más circunstâncias com que fui provado em tempos recentes funcionaram como óleo no fogo do inferno que ardia em mim.

A esposa, dizem, é a casa. A dona imprime à casa sua aparência e personalidade. Comprovei, de fato, esta verdade. De minha mulher não quero falar. Eu a perdôo... As considerações são apenas sobre a casa. Minha casa não tinha aparência, era desleixada; parece-me que o mobiliário era opulento, enfeites, bibelôs; tudo, porém, estava sujo, imundo; era repulsivo de ver, aparentava o demônio. Lá reinava a melancolia, o odor era de velhas ruínas. Em nada lembrava um lar. Nos anos de juventude, com vida e poder, estava mergulhado no dinheiro, sempre no alvoroço, não me importava - paciência, não era nada! Quando eu queria um pouco de vida, obter prazer, procurava fora. Na velhice, no entanto, quando se deseja sossego, estar com familiares em casa, senti demais minha solidão, a tragédia de minha vida: eu não tinha um lar; isto tornou minha vida horrorosa. Examinando todos os meus atos no decorrer de minha vida, lamentei profundamente. Dizia para mim mesmo: Meu Deus, como eu pequei! E me indagava: Para que, pelo amor de Deus, me serviram todo meu empenho, todos os meus atos? Para que toda a riqueza, para quem?... Dois filhos meus, fracos e adoentados morreram há pouco tempo, partindo meu coração. Abatido como após uma hecatombe eu continuava me questionando num estado de ânimo amargo: De que me serve toda a riqueza se me sinto tão solitário, se não tenho casa, não tenho um lar? Ai, Senhor do Universo, eu pequei terrivelmente - socorro, e em favor de quem?

Nessas ocasiões eu sempre me lembrava do bom e pacato Gutman. Ele era cordial e prestativo com todos. Ele era, coitado, pobre, porém sua casa era iluminada e cada cantinho brilhava! Quanta satisfação ele tinha de sua bela e prendada esposa, bem como de suas filhas boas e estudiosas, que o amavam e respeitavam! Ele passava privações, no entanto, estava sempre alegre e contente... 
Uma vez lembro de sua esposa ter chorado muito. Era véspera da Páscoa, faltavam apenas alguns dias e não havia ainda nenhum sinal de preparativo para a festa. O dia inteiro, ele mandou-me sair com seus livros, porém, ninguém se interessou. Todos a quem eu entregava uma propaganda torciam o nariz, sem responder nenhuma boa palavra. Sua boa e fiel esposa, que o amava muito, chorava desesperada.

- Por favor! - disse Gutman, querendo consolá-la. - Por Deus, não peque, derramando lágrimas. Para nós ainda é melhor que para pessoas que enriqueceram fraudulentamente, que preparam a festa à custa de dinheiro desonesto. Nós não tiramos nada de ninguém, não fizemos nenhum mal, Deus o livre. Estamos sofrendo?... É melhor e mais bonito sofrer pela verdade do que gozar pela mentira. Não se preocupe, minha vida! Deus sempre nos ajudou e continuará ajudando. Ele não terá alternativa, encontrará alguma forma. De que me servem dois paletós e um sobretudo? Não consigo usar os dois simultaneamente, além do que, o verão está próximo e o sobretudo guardado ainda pode ser comido por traças. Então, por favor, Avreml, vá prontamente levar meu paletó e meu sobretudo para empenhar ou vender; assim teremos dinheiro para comprar o pão ázimo e demais coisas necessárias para a festa.

Esta cena era recorrente em minha memória. Constatei que Gutman era feliz mesmo sem dinheiro. Fica então inferido que a felicidade não consiste em dinheiro, porém em algo diferente - só pessoas direitas são felizes e alegres. Veio à minha memória o que dissera uma vez Jacobsohn: "Sofrer significa adular e ser hipócrita. $O$ adulador e o dissimulado precisam sempre se comportar assim, necessitam acautelar-se como um ladrão". Só agora comecei a perceber com evidência quão verdadeiras e certas eram suas palavras. Gutman aquilatava com seu raciocínio que para o adulador e o hipócrita era tão ruim quanto para o ladrão, porque todos eles devem sempre ter medo, estar sempre atentos para não serem desmascarados, nem as suas feias atitudes. Não é muito agradável sempre sentir medo e precisar esconder-se.

Eu senti o mesmo, emocionalmente no meu coração - que uma pessoa dissimulada não pode nunca sentir-se feliz. Sente-se sempre cobrado, como uma pedra no coração, o sangue a ferver e a cabeça a estourar - os fogos do inferno queimam dentro dele. $O$ mundo the é apertado e não sabe 
onde se meter. Ele gostaria de escapar de sua pele e fugir de si mesmo, a algum lugar no fim do mundo, longe, longe, no *quinto dos infernos.

Eu costumava ter sonhos terríveis. Parecia-me estar segurando uma faca e degolando. Ouvia, constantemente, gemidos, suspiros, roncos e estertores. Minhas roupas estavam empapadas de sangue. Mikhl, o bom e reservado Mikhl, sempre aparecia diante de meus

*Vu der shvartzer fefer vakst onde cresce a pimenta preta. Metaforicamente significa no fim do mundo. Justifica-se assim a expressão no quinto dos infernos. olhos, mortalmente pálido. Encarava-me, tristemente, mostrando-me os grilhões aos quais estava preso e indagava com sofrimento:

- Por Deus, Itzhok Avrom, o que foi que eu lhe fiz?...

A velha e Sheindele costumavam surgir de dentro da terra, tossindo e sufocando. Corroíam-me com seus flamejantes olhos vermelhos gritando: - Eis nosso anjo da morte! Assassino! Degolador! - Em seguida transformavam-se em montes de ossos dos quais emergiam vermes e cobras possantes, que vinham em minha direção com as bocas abertas; mordiam e furavam como agulhas...

Mais que todos mortificava-me Golde. Eu a via sempre abatida, devastada, amargurada, sempre com um trabalho nas mãos. Ela furava os dedos com a agulha, não aparentando sentir, sem fazer um gesto, continuava costurando como uma máquina e sacudia, embalando com o pé, um pesado berço rangente. Cantava uma canção de ninar com uma voz triste e estranha. O berço, porém, está vazio: não há ninguém. Golde! Grito eu - Onde ele está? Onde está a criança? Golde continua a cantar, embalando com o pé, sem me dirigir a palavra:

$\mathrm{Ai}$, lu lu lu, criança infeliz

Pobre mãe, coitada e sofrida

Dentro do bercinho

Há um claro e branco cabritinho

Cabritinho mé, cabritinho mé!

Não grite, não chore

Você foi abandonado

Cabritinho mé, cabritinho mé!

Desolado e escuro é seu mundo, 
Sofra calado a fome e o frio -

Cabritinho mé, cabritinho mé!

Lá fora, escute só,

Uiva um lobo, rosna um urso -

Cabritinho mé, cabritinho mé!

Vazio está o bercinho

Oi, não está mais o branco e claro cabritinho!

Ai, lu lu lu, criança infeliz

Pobre mãe, coitada e sofrida

Após o canto, Golde se levantou, lágrimas de sangue jorravam de seus olhos, estendeu os braços para todos os lados e gritou numa voz selvagem: Sumiu o branco e claro cabritinho! Saí correndo de casa, muito impressionado, parecia ver lobos e ursos esmigalhando com os dentes tenros ossinhos - ouviam-se ao longe lamentos amargos de um pobre e infeliz cabritinho... 


\section{XXVI}

Preocupação no coração do homem, o coração está cheio de aflições - diz o versículo - tudo deve ser posto para fora. Carregar as desgraças, não revelá-las, é uma dor insuportável. É uma caldeira de aço em ebulição, que pode explodir quando o vapor não encontra uma saída. Em meu coração cozinhava mais que numa caldeira - queimava nele um inferno!... Contas antigas de meus atos pecaminosos, sentimentos amargos e horríveis, sonhos tenebrosos, tudo junto, como colunas compactas flamejantes estraçalhavam-se dentro de mim para me aniquilar. Melhor, para o pecador, estar no inferno do que ter o inferno dentro de si.

Só então concluí que o homem carrega o inferno e o paraíso dentro de si. Seu juiz está ali sentado na cadeira da justiça, dentro dele. Ah, se eu pudesse verter meu coração, amainar um pouco meus sofrimentos! Eu, infelizmente, não contava com ninguém. Ouro e prata acumulei bastante, porém, bons amigos - nenhum.

Considero uma grande clemência, por parte do Criador ter-me possibilitado uma maneira de expressar meus sentimentos, se não por meio da boca, pelo menos pela escrita.

O mesmo Deus que indicou a Moisés uma árvore para adoçar a água amarga no deserto, indicou-me, também, a maneira de minorar meus sofrimentos - a caneta.

Nos momentos mais difíceis e mais amargos, quando meu coração estava dolorido, aprendi a extravasar no papel meu desconsolo, do jeito que podia. No começo senti dificuldade porque não estava acostumado, com o tempo jorrava espontaneamente, como se estivesse contando a um bom amigo a quem abria meu coração. Consegui escrever toda minha biografia e ao relê-la, do início ao fim, senti meu coração um pouco aliviado! Os pecados já não me pareceram tão graves. Meus pecados já não eram exclusivamente meus, porém, boa parte deles, talvez a maior parte, fosse decorrente da sociedade e de seus maus costumes.

Tomemos como exemplo as escolas judaicas - os Talme-Toires!

Pegam-se crianças pobres, órfãs coitadas, que são encurraladas numa ruína, lamentavelmente, num estábulo, onde ficam abandonadas, 
famintas, desmazeladas, no lixo e na imundície, apanham surras e safanões o quanto nelas cabe. Aprender - não aprendem nada. Fazem delas desocupados, pessoas infelizes, inúteis para Deus e para os homens. Não melhores que os professores selvagens, infelizmente, são os presidentes das instituições que sacodem caixas de esmolas, extorquem o quanto podem, aparentemente em prol das crianças judias.

Sua meta é transformar as crianças pobres em judeus, e os judeus em animais domésticos, não mais seres humanos...

Não foi pouco o que suportei quando criança, um pobre e solitário órfão, na escola Talme-Toire?! Não me refiro aos maus tratos físicos que infligiram em meu corpo magro, pois era natural, eu, como criança pobre, passar fome, frio e surras, mas, refiro-me à minha alma. Meu Deus, o que tinham contra ela? Minha alma humana foi rebaixada, meus sentimentos foram corrompidos. Além de não me ensinarem a viver como gente no mundo, mataram o sentimento de honra, de dignidade humana, através de seu tratamento repulsivo, com seus xingamentos e palavras de baixo calão.

Este é todo o ensinamento, todo o judaísmo, que os caridosos judeus dispensavam às crianças pobres!

Outro exemplo a ser analisado é o ofício, a profissão.

Exercer um ofício, como se sabe, não é bem conceituado entre os judeus. Da mesma forma que um desocupado, um eterno frequentador de casa de estudos, não passa de uma tapeação, assim um artesão é um demérito para a família. Aquele que quer manter uma vida respeitosa, mesmo que inche de fome, por não ganhar o suficiente, não quer que seus filhos aprendam qualquer ofício que seja. Essa é a razão da existência de órfãos descuidados provenientes das camadas mais humildes e rudes. Estes serão colocados como aprendizes de artesãos e ninguém se preocupará

*Todos os verbos empregados neste parágrafo são formados pelo verbo trogn - carregar, precedidos de prefixos que lhe alteram ou reforçam o significado. Exemplos: trogn, ontrogn, arumtrogn, tzutrogn, optrogn, fartrogn. com sua aprendizagem, nem com a forma como serão tratados.

*O ofício começa, geralmente, com todos os trabalhos pesados e sujos: carregar e despejar as águas servidas, buscar água do poço, ocupar-se com crianças da casa, servir como carregador durante as compras da patroa, entregar trabalhos aqui e ali, ocupar-se sempre com o serviço da casa, atendê- 
la em todos seus caprichos, funcionar como menino de recados e além de tudo, suportar surras e ultrajes.

Como complemento o aprendiz fica imerso numa linguagem de baixo calão dos trabalhadores e histórias de amores de todo o tipo. Caso tenha restado uma centelha de humanismo, ela é logo apagada. Assim começa a aprendizagem de um ofício. E como termina? Em nada! Aprende-se a fazer um mau trabalho.

Culpar os artesãos por esta situação também não é correto, porque eles também começaram assim, como eu e milhares de crianças pobres, carregando águas servidas e lixo, além de sofrerem as maiores humilhações. Ainda soa em meus ouvidos a canção que o pequeno sapateiro cantava quando me via descarregando as águas servidas. "Honra seja dada a Itzinhu! Carregue, carregue, Itzik Avreiminhu! Eu também carreguei bastante na sua idade".

Meu Deus do céu, eu sou um pecador! Mas o pecado não é só meu. Eu agradeço ao Senhor por ter me aberto os olhos!

O Senhor do Universo abriu-me os olhos com uma finalidade! Vou fazer o possível para evitar esta situação, mostrando aos judeus o caminho adequado para minorar os erros cometidos contra as pobres criancinhas, coitadas.

De acordo com meu testamento, do qual Ihe envio uma cópia, rabino, deixo minha grande casa, onde deverá ser feito um Talme-Toire para crianças pobres, bem como uma escola para ensinar-lhes ofícios. Os rendimentos dos meus vários negócios e parte dos juros do meu capital que eu lego a um fundo permanente de beneficência devem ser destinados à manutenção de ambas as escolas. No Talme-Toire, além de Judaísmo e da língua santa, o hebraico, quero que seja ensinada também a língua do país além de conhecimentos gerais para fazer das crianças judeus e seres humanos igualmente, que sirvam para Deus e para o mundo. Na outra escola desejo que se ensinem matérias religiosas e profissionais simultaneamente, para que os alunos sejam educados de forma a não sentirem vergonha, ofensas nem humilhações e saiam de lá bons profissionais, conscientes de seu próprio valor e obrigando os outros a reconhecer também este valor. 
Para alcançar estes objetivos se faz necessária a contratação de bons professores, pessoas com sensibilidade e compreensão, com coração e cérebro, que entendam e gostem de sua profissão. O principal é o amor, pois eles deverão lidar com crianças pobres, abandonadas e solitárias, que carecem de carinho e atenção, assim como qualquer ser vivo. Uma palavra de incentivo produz melhor resultado que castigos e lições de moral, e predispõe a uma obediência sadia. Foi o que senti durante minha infância.

Todos estes planos demandam boa administração para que os objetivos sejam alcançados eficientemente. É meu desejo que esta administração seja exercida pelo senhor, rabino, e pelo senhor Gutman. Com a liderança dos dois, as novas escolas integrarão conhecimento e sabedoria. $\mathrm{O}$ senhor, rebe, supervisionará os estudos judaicos, para que sejam ensinados bem e adequadamente, e Gutman, de sua parte, supervisionará os demais assuntos de cultura. Como os conheço a ambos em profundidade, sei que ficarão satisfeitos um com o trabalho do outro. Vocês dois almejam o bem para o povo de Israel e se empenharão com todas as forças para consegui-lo. A remuneração, por todo este trabalho e dedicação, está estipulada no testamento.

As entradas de capital para o Fundo Permanente de Beneficência o senhor, junto com Gutman, usarão para outras necessidades da cidade, a seu critério. Talvez seja uma boa idéia introduzir na cidade uma escola elementar, um kheider, para muitos alunos, com excelentes professores, tanto para a área judaica como para a de conhecimentos gerais, onde os alunos aprenderiam a ser autênticos judeus e pessoas úteis e compreensivas. Eu teria muito prazer que isto acontecesse desde que sempre sob a liderança dos dois e sob os auspícios do referido Fundo Permanente de Beneficência.

Tenho certeza que este tipo de escola, dirigida por pessoas como o senhor e como Gutman, será para as crianças judias uma bênção. Sei, porém, que aquilo que é bom para as crianças poderá desagradar muitos tipos de pessoinhas que se oporão. Eles colocarão suas artimanhas como sendo religiosas alegando ser o empreendimento antijudaico. Acharão todos os recursos para impedir. No entanto, os senhores se empenhem com todo o seu vigor. Talvez Deus tenha piedade. 
O que vai ser feito na minha cidade para crianças pobres através de mim, ainda não é suficiente. "Uma andorinha não faz verão". Outras pessoas devem ser mobilizadas a fim de fazer o mesmo em todas as localidades onde haja judeus. Por isso solicito que minha confissão e meu testamento sejam impressos, para ressoar nos ouvidos das pessoas abastadas e boas, em todos os lugares do mundo judeu. Mesmo que minhas palavras não influenciem as pessoas a se tornarem melhores em vida, a entenderem como ajudar os pobres, a fazerem o bem e como viver, pelo menos poderão ensinar como morrer... Todos os ricaços que cheguei a conhecer no meu mundinho permaneceram até o fim exatamente aquilo que sempre tinham sido morreram como tolos. Que eles conheçam minha confissão e meu testamento e tomando-me como exemplo, aprendam, pelo menos, a morrer, deixando este mundo como pessoas dignas.

Morram ricaços, morram - morram como pessoas dignas!...

Porém como os *"ricaços de sua cidade têm

${ }^{*}$ Neguidei irekha kodmim - em hebraico no original, conferindo veracidade à afirmação.

prioridade", e como a impressão da confissão e do testamento demorará para ficar pronta, peço-lhe, rabino, que antes de meu enterro, o senhor os leia para as pessoas de destaque do local. Para mim - será a expiação de pecados e para eles - uma lição de moral. Tudo bem, que eles fiquem sabendo!...

Para organizar esses meus papéis adequadamente e corrigir meus erros crassos, acrescentar um pouco de tempero e aprimorar o estilo para sua publicação em brochuras a serem distribuídas - só existe uma pessoa eficiente, Reb Mêndele Moikher Sforim, o vendedor de livros. Lembro dele quando ainda era um homem jovem, em Tsevuetshitz. Por favor, rabino, entregue-lhe os papéis e espero que ele cumpra a minha vontade da melhor forma possível. É óbvio que ele deve ser bem pago por seu empenho. 


\section{XXVII}

Quando o rabino acabou a leitura colocando os manuscritos sobre a mesa, fez-se um alvoroço. Os ricaços ficaram muito irados. Alguns apenas morderam os lábios, outros suspiraram; alguns gemeram, outros resmungaram.

- Por que está suspirando tanto, Reb Khone! - Falou um ricaço e também suspirou.

- Tá, tá, tál - Reb Khone sacudiu a cabeça - Vejam, onde ele foi parar! Não dá mais para confiar nas pessoas... O mundo não é mais o mesmo... Que vergonha! Que vergonha! Que horror! Juro, um susto! Até parece que hoje, Reb Berish....Que coisa, que coisa!

- Eu já havia entendido antes, porém - Respondeu Berish - para onde era disparada a bala. Ai, ai, Reb Khone, eu tenho um faro para estas coisas... A troco do que ficamos sentados feito bobos, esperando até que a bala nos atingisse? Eu não disse: Vamos!? E por que os senhores permaneceram para ouvir as admoestações amargas até o fim?... Porém, reconsiderando! Bem, paciência... Foi de fato ofensivo, porém, já ouvimos coisas semelhantes, Reb Khone?!... Talvez no começo o senhor tivesse tido razão... Enfim, fazendo um retrospecto: um tolo permanece um tolo, e o mundo permanece o mesmo, como antes...

- Não, não rabino! - Alguns ricaços protestaram muito ofendidos. - Isto é inusitado... Atirar tais coisas na cara das pessoas!? Fazê-las e fazernos de... Com o perdão da palavra. Quem Ihe pediu? Fale de si próprio, escreva... Que direito se tem para imiscuir-se na vida dos outros? Não rabino, é uma grande injustiça.

- E então, Reb Mêndele?! - Dirigiu-se o rabino a mim, após a saída das pessoas - Diga-me o senhor, quem é este tal de Gutman em Tsevuetshitz?

- Saí de lá há muito tempo, logo que me tornei um vendedor de livros mudei-me com a família para Kabtzansk, e hoje sou um judeu de lá!

- Porém o senhor conhece o senhor Gutman, Reb Mêndele? 
- Sim, rebe. Eu o recordo muito bem - era um alemão com a barba bem aparada. Uma pessoa muito boa, muito correta. É como se diz: "Melhor um judeu sem barba, que uma barba sem judeu".

- Peço-lhe, então, que faça o favor de viajar, prontamente, para Tsevuetshitz, como portador de uma carta minha, solicitando sua presença, para que possamos cumprir a vontade do morto o mais cedo possível. Prezado Reb Mêndele, rogo-Ihe também, que providencie a publicação destes escritos em muitas brochuras e as espalhe por todos os cantos, a um preço módico, para que as pessoas possam comprar mais. A sua remuneração será justa, se Deus quiser.

Voltando à sinagoga encontrei meu cavalo em péssimas condições, coitado. Arruaceiros haviam aprontado. Arrancaram-lhe quase todo o rabo, deixando-lhe apenas alguns fios. Para comer só lhe deram açoites. Estava parado sério, com a mandíbula inferior caída, olhando pensativo para os livros da carroça. O que um cavalo pensa olhando para livros, não é para nosso raciocínio aquilatar. Só sei que o meu azarado cavalo olhava e pensava, olhava e pensava - à moda cavalar... Porém, isto é irrelevante... Não é a isto que me refiro...

- E então, inteligência rara! Falo-lhe, segurando-o pela crina Meu pobre coitado, hoje você merece ração dupla de aveia. Você fez uma coisa boa, trazendo-me para Glupsk. Com sua inteligência você foi de utilidade, tanto para mim, como para a literatura! Você entende, cavalo, o que você fez? Que bela composição coube-me agora lançar ao mundo, tudo graças a você, graças à sua perspicácia tomando a direção de Glupsk! De hoje em diante, cavalinho, minha inteligência rara, solto as rédeas, aposento o chicote e você me conduz!...

No dia seguinte aprontei todas as coisas necessárias e me pus a caminho!

Chegando em Tsevuetshitz inteirei-me da saída de Gutman da cidade, sem que ninguém soubesse de seu paradeiro. Dediquei-me então à minha tarefa: publicar o referido livro. Não poupei esforços para que ele saísse 
"a contento e alegremente" como se diz - esférico e contundente... Ainda quero acrescentar:

\section{COMUNICADO}

Prezados senhores! Quem dos senhores sabe onde se encontra o Senhor Gutman, ou eventualmente se encontrará com ele, favor comunicarIhe que, em nome de Deus, ele deve dirigir-se a Glupsk, onde é aguardado pelo rabino local, a fim de juntos instituírem a afamada Talme-Toire com uma escola profissional para formação de artesãos, bem como aprimorar outras boas coisas.

Judeus misericordiosos, tenham compaixão e façam-no em prol das crianças judias pobres!... 


\section{BIBLIOGRAFIA}

ABERBACH, David. Realism, Caricature and Bias. The fiction of Mendele Moikher Sforim. The Littman Library of Jewish Civilization, London, 1993.

ABRAMOVITSH, S. Y. A Segule Tzu lidishe Tzores (Um remédio para os males judaicos

Contos

Di Alte Maisse (A Velha História)

Di Nisrafim (Os Queimados)

Eltern un Kinder (Pais e Filhos)

In Shturem Tzait (No Tempo da Tempestade)

Shabes un lom-Tef (Sábado e Feriado)

Shem un Yefet in a Vogn (Sem e Jafé no Vagão do Trem)

Tzurik Aheim (De Volta para Casa) In Ale Verk - Varsóvia, 1927.

Di Takse (O Imposto)

Dos Kleine Mentshele (O Pequeno Homenzinho) In Ale Verk - Ycuf - NY, 1946.

AGNON, Shai. Khob Gueshribn in Loshn Yiddish. In Yidish un Yidishkeit (Ídiche e Judaísmo). World Council for Yiddish. TA, 1986.

AUBERT, Francis Henrik. As (In) Fidelidades da Tradução. Editora UNICAMP, 1994.

AUBERT, Francis Henrik. Modalidades de Tradução: Teoria e Resultados. In Trad Term, número 51, Humanitas, São Paulo, 1998.

AUSUBEL, Nathan. Conhecimento Judaico. Vol. IV, Ilustração Judaica. Editora Tradição, Rio de Janeiro, 1967.

BARIAKH, Barukh. Elementare Gueshikhte fun der lidisher Literatur. Curitiba, 1942.

BEREZIN, Rifka. As Origens do Léxico do Hebraico Moderno. USP, Depto. De Linguistica, Línguas Orientais, 1980.

BENBEJI, Amir. Mendele vehaSipur haLeumi (Mendele e o Conto Nacional), Editora Dvir, Instituto Heksherim, 2009.

BERKOVITSH, I. D. Sholem Aleikhem un Mendele. Vol. XI, Varsóvia, 1928.

BIALIK, Khaim Nakhman. Vol. I, Varsóvia, 1928.

BLOOM, Zeev. Dem Zeidns Kroin (A Coroa do Avô).

DUBNOV, S. Mendeles Zikhroines (Lembranças de Mendele), Vol. XI, Varsóvia, 1928. 
FLECK, Jeffrey. In Search of a Hero. Tese de Doutorado, Universidade da California, Berkeley, 1981.

GRAYZEL, Solomon. A História Geral dos Judeus. Editora Tradição, Rio de Janeiro, 1967.

GURI, Yossef. Voss Darft ir Mer? (Do que mais Vocês Precisam). Dois mil ditados em ídiche, Universidade Hebraica, Jerusalém, 2002.

GURI, Yossef. Oifn Shpitz Tzung (Na Ponta da Língua). Quinhentos Ditados em Ídiche, Universidade Hebraica, Jerusalém, 2006.

HALKIN, Simon. Modern Hebrew Literature. Pag. 67 a 73, O Declínio da Haskalá.

HARSHAV, Benjamim. O Significado do Ídiche. Tradução de Jacó Guinsburg. Editora Persperctiva, São Paulo, 1994.

HESHEL, Avraham Yehoshua. A Mekhaie tzu redn Yiddish, in Ídiche e Judaísmo, World Council for Yiddish, TA, 1986.

KAGANOWSKI, Efraim. lidishe Shraiber in der Heim. (Autores Judeus na Intimidade). Editora Ofsnai, Paris, 1956.

KLAUZNER, Yossef. As Conversas Profanas de Mendele. Vol. XXI, todas as obras de Mendele, Varsóvia, 1927.

KOOK, Avraham Y. Tzu Voss Tzilt der Deguel Yerushalaim, in Ídiche e Judaísmo, World Council for Yiddish, TA, 1986.

KRESSEL, G. Léxico da Literatura Hebraica nas Últimas Gerações, Vol. II, Merhavia, Sifriat Poalim, 1967.

KUCINSKY, Meir. O Conto Ídiche - Introdução. Editora Perspectiva, São Paulo, 1966.

KURI, Leo. O Mundo Literário de Jorge Luiz Borges, tradução hebraica por Yoram Bronovski, Sifria Khadashá, Hotzaat Kibutz Hameuhad.

LEBEL, Mireille Hadas. O Hebraico: $\mathbf{3 0 0 0}$ anos de história, editora Albin Michel, Paris, 1992.

MAFFEI, Marcos. As Históricas Entrevistas dos Escritores em Paris Review, Companhia das Letras, 1998.

MEIZEL, Nakhman. Der Mendeles Turem (Histórias sobre Mendele), Vol. XI, Varsóvia, 1927. 
MEIZEL, Nakhman. Forgueiers un Mittzaitler (Precursores e Contemporâneos), lcuf, NY, 1946.

MILTON, John. Tradução, Teoria e Prática. Editora Martins Fontes, 1998.

MIRON, Dan. Der Imaj Fun Shtetl (A Imagem do Shtetl). Editora I. L. Peretz, Israel, TA, 1981.

MIRON, Dan. Tales of Mendele the Book Peddler. Introduction. Edited by Dan Miron \& Ken Frieden, Schocken Books, NY, 1996.

MOKDONI, A. Tzvei Mentchn (Duas Personas). Vol.I, Varsóvia, 1928.

NIGUER, S. Mendele Moikher Sforim, un zain Lebn (Mendele, sua vida, sua obra social e literária), Congresso Judaico Mundial, NY, 1970.

NOVERSHTERN, Avraham. Hassafrut vehaKhaim (A Literatura e a Vida). Florescimento da Moderna Literatura Ídiche. Editora Universidade Aberta, TA, 2000.

ORMIAN, Chaim. Di Shtelung fun der Shtudirndiker lugnt (A Posição da Juventude em Israel em relação a Mendele no pós guerra). Anais do YIVO, NY, 1948.

PRILUTZKI, N. Mendeles Yiddish (O ídiche de Mendele). Vol. XXII, Varsóvia, 1928.

RICOEUR, Paul. História e Narratividade. Editora Paidos, Barcelona, 1999.

ROSKIES, David G. What is Jewish Literature. The Jewish Publication Society Philadelfia, Jerusalém, 1994.

SACHAR, Howard Morley. O Curso da Moderna História Judaica. Editora Tradição, Rio de Janeiro, 1967.

SCHACHTR, Allison. The Shtetl and the City. In Jewish Social Studies: History, Culture, Society n. 03, 2006.

SELIGMANN, Marcio. Filosofia da Tradução: Tradução de Filosofia. In cadernos de tradução III, Universidade Federal de Santa Catarina, 1998.

SHAKED, Gershon. A Literature against all odds. Modern Hebrew Fiction, Blumington: Indiana Universiti Press, 2000.

SHAKED, Gershon. Bein Skhok Ledima (Entre o Riso e a Lágrima). Editora Massada, TA, Israel, 1965.

SHAKED, Gershon. Sombras de Identidade. Editora Perspectiva, 1988. 
SIMON, Joseph. A Biografia de Itzkhok Avrom, o Homem Violento. Pangloss Press, NY, 1991.

SNEH, Simkha. Breve Historia del Idish. Congreso Judio Latino Americano, Buenos Aires, 1977.

SOLOVEITSHIK, Yossef. Vegn Yiddish (Sobre Ídiche). In Ídiche e Judaismo, World Council for Yidish, TA, 1986.

STEINBERG, Theodore L. Mendele Moikher Sforim. State University of NY at Fredonia Towayne Publishers, GK Hall \& Co, Boston.

STILLMAN, Gerald. Introduction to The Little Man. Translations, Pangloss Press, 1991.

TODAR, Shimon. Imrot Mendele (Expressões de Mêndele). Academia de Língua Hebraica, Jerusalém, 1970.

WALDMAN, Berta. Linhas de Força. Escritos sobre literatura hebraica. Associação Edit. Humanitas, 2004.

WEINREICH, Max. Bilder fun der Yiddisher Literatur Gueshikhte: fun di Onheibn biz Mendele (Quadros da História da Literatura ídiche). Vilna: Tamar, 1928.

WERSES, Shmuel. Bicoret haBicoret (Crítica da Crítica). Editora lachdav, TA, 1982.

WERSES, Shmuel. MiMendele ad Hazaz (De Mendele a Hazaz). Universidade Hebraica, Jerusalém, 1987.

WERSES, Shmuel. Sipur veShorashó (O Conto e sua Fonte). Editora Massada, Ramat Gan, 1971.

ZINBERG, I. Historic Cultural Studies. Morris S. Sklarsky, NY, 1949.

ZOHAR, Itamar Even. Estudos da Cultura Judaica. Homenagem ao jubileu de Khone Shmeruk, Editado por Zalman Shazar Center for Jewish History, Jerusalem, 1993. 


\section{BIBLIOGRAFIA NA INTERNET}

- Escritos hebraicos de Mêndele estão disponíveis no projeto Ben Yehuda de registro da literatura hebraica http://benyehuda.org/mos/

- Escritos em ídiche em Steven Spilberg Digital Yiddish Library http//wwwarchive.org/search.php?query=mediatype\%3Atests\%20AND\%--

- Importante periódico de ídiche transliterado sobre língua e cultura Iprager@research.haifa.ac.il

http://library.osu.edu/sites/users/gabron.1/02002.php 